\title{
Arbeidsmarktmonitor metalektro 2003
}

Citation for published version (APA):

de Grip, A., van Loo, J. B., \& Sieben, I. J. P. (2004). Arbeidsmarktmonitor metalektro 2003.

Researchcentrum voor Onderwijs en Arbeidsmarkt, Faculteit der Economische Wetenschappen. ROA Reports No. 2 https://doi.org/10.26481/umarep.2004002

Document status and date:

Published: 01/01/2004

DOI:

10.26481/umarep.2004002

Document Version:

Publisher's PDF, also known as Version of record

\section{Please check the document version of this publication:}

- A submitted manuscript is the version of the article upon submission and before peer-review. There can be important differences between the submitted version and the official published version of record.

People interested in the research are advised to contact the author for the final version of the publication, or visit the DOI to the publisher's website.

- The final author version and the galley proof are versions of the publication after peer review.

- The final published version features the final layout of the paper including the volume, issue and page numbers.

Link to publication

\footnotetext{
General rights rights.

- You may freely distribute the URL identifying the publication in the public portal. please follow below link for the End User Agreement:

www.umlib.nl/taverne-license

Take down policy

If you believe that this document breaches copyright please contact us at:

repository@maastrichtuniversity.nl

providing details and we will investigate your claim.
}

Copyright and moral rights for the publications made accessible in the public portal are retained by the authors and/or other copyright owners and it is a condition of accessing publications that users recognise and abide by the legal requirements associated with these

- Users may download and print one copy of any publication from the public portal for the purpose of private study or research.

- You may not further distribute the material or use it for any profit-making activity or commercial gain

If the publication is distributed under the terms of Article $25 \mathrm{fa}$ of the Dutch Copyright Act, indicated by the "Taverne" license above, 


\title{
Arbeidsmarktmonitor Metalektro 2003
}

\author{
ROA-R-2004/2
}

Andries de Grip

Jasper van Loo

Inge Sieben

Researchcentrum voor Onderwijs en Arbeidsmarkt

Faculteit der Economische Wetenschappen en Bedrijfskunde Universiteit Maastricht

Maastricht, april 2004 
ISBN 90-5321-387-2

Sec04.019.doc 


\section{Inhoud}

Bladzijde

Voorwoord

Managementsamenvatting iii

1 Dynamiek in de Metalektro 1

1.1 De conjuncturele dip 1

1.2 Blijft het werk in Nederland? 6

1.3 Naar een toenemende kwaliteit van de productie 9

2 De structuur van de werkgelegenheid $\quad 15$

2.1 Bedrijven in de Metalektro $\quad 15$

2.2 Werknemers in de Metalektro 20

$\begin{array}{lll}2.3 & \text { Belangrijkste beroepen en opleidingen } & 24\end{array}$

3 Instroom, doorstroom en uitstroom van personeel 27

3.1 Het totaalbeeld in de afgelopen twee jaar 27

$\begin{array}{ll}3.2 \text { De instroom van nieuwe werknemers daalt } & 28\end{array}$

$\begin{array}{ll}3.3 & \text { Uitstroom in de Metalektro } \\ 3.4 & 31\end{array}$

3.4 Werkgelegenheidsontwikkeling en dynamiek 32

$\begin{array}{ll}3.5 & \text { Doorstroom van personeel } \\ \end{array}$

4 Krimpende werkgelegenheid en toch vacatures?

$\begin{array}{ll}4.1 & \text { Krimpende werkgelegenheid } \\ 4\end{array}$

$\begin{array}{ll}4.2 \text { Vacatures } & 39\end{array}$

4.3 Problemen bij het vervullen van vacatures 43

4.4 Werving, selectie en interne aanpassingen 46

5 De noodzaak van scholing 51

5.1 Waarom scholing? 51

5.2 Scholing in de Metalektro 58

5.3 Het bevorderen van scholing 63

6 HRM-beleid en employability $\quad 71$

6.1 Het belang van een goed HRM-beleid 71

$\begin{array}{ll}6.2 \text { HRM in de Metalektro } & 72\end{array}$

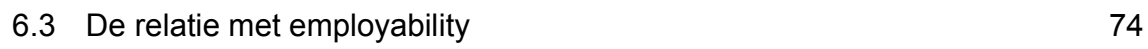

6.4 Een vergelijking met twee andere industriële sectoren 78

7 De Metalektro in de toekomst 81

7.1 Hoe ziet de arbeidsmarkt in de Metalektro er in de komende jaren uit?

7.2 Technische werknemers met pensioen: en dan? 87

$\begin{array}{ll}7.3 \text { Agenda voor de toekomst } & 90\end{array}$ 



\section{Voorwoord}

In opdracht van de Stichting $\mathrm{A}+\mathrm{O}$ is begin 2002 de Arbeidsmarktmonitor Metalektro opgezet. Deze monitor geeft inzicht in de actuele en toekomstige ontwikkelingen die van belang zijn voor de Metalektro, zowel op landelijk als op regionaal niveau. Dit rapport vormt de afsluiting van de tweede jaarcyclus van deze monitor. Het rapport presenteert de belangrijkste resultaten uit twee informatiebronnen: het speciaal voor deze monitor opgezette Werkgeverspanel Metalektro en de beschikbare actuele landelijke arbeidsmarktinformatie over (en trends in) de personeelsopbouw van de verschillende bedrijfssectoren binnen de Metalektro en van de verwachte knelpunten in de personeelsvoorziening. Op een aantal punten wordt dit aangevuld met informatie uit enkele andere bronnen.

In het Werkgeverspanel Metalektro beantwoordt een representatieve groep bedrijven uit de Metalektro ieder kwartaal - via Internet - vragen over de in- en uitstroom van personeel en de openstaande vacatures. Daarnaast geven zij informatie over belangrijke veranderingen in hun bedrijf, werving en selectie, de inzetbaarheid van personeel, scholing en het gevoerde HRM-beleid.

Bij de start van het panel in januari 2002 zijn alle Metalektrobedrijven, die aangesloten zijn bij de werkgeversorganisatie FME-CWM en vallen onder de CAO Metalektro, benaderd om deel te nemen aan het werkgeverspanel Metalektro. Van de ruim 1.200 bedrijven reageerden er 345 positief. In de loop van 2002 en 2003 heeft een aantal bedrijven zich afgemeld (paneluitval), maar zijn er ook enkele nieuwe bedrijven bijgekomen. Ook is er in het najaar van 2003 een nieuwe uitnodiging naar alle Metalektrobedrijven gestuurd om mee te doen aan het panel. Het aantal bedrijven dat een vragenlijst heeft ingevuld varieert van 173 bedrijven in het eerste kwartaal van 2003 tot 119 bedrijven in het vierde kwartaal van 2003. Ook is er in november 2003 via Internet een vragenlijst voorgelegd aan een lid van het management of directie van de Metalektrobedrijven die aan het panel deelnemen. Uiteindelijk hebben 104 bedrijven de vragenlijst van deze managementmeting ingevuld.

Om na te gaan of de gegevens van deelnemende bedrijven representatief zijn voor alle bedrijven in de Metalektro, is gekeken naar de bedrijfsomvang, bedrijfssector en regio van de bedrijven. Op basis van deze drie kenmerken zijn de gegevens van de deelnemende bedrijven gewogen. Deze techniek zorgt ervoor dat de representativiteit van het Werkgeverspanel Metalektro bewaakt is. Om vervolgens uitspraken te kunnen doen over bijvoorbeeld het totaal aantal vacatures dat in de Metalektro openstaat, is het aantal vacatures dat bij de deelnemende bedrijven openstaat opgehoogd. Deze ophoging van vacaturecijfers komt overeen met de procedure die het CBS volgt in hun vacature-enquête. Dit heeft als voordeel dat we de ontwikkeling kunnen schetsen van het totaal aantal vacatures in de Metalektro. Ook bij de cijfers over de in- en uitstroom van werknemers in de Metalektro is een ophoging tot totalen voor de hele sector toegepast. 
De uitkomsten van de metingen van het Werkgeverspanel Metalektro worden elk kwartaal gepubliceerd in een door de Stichting $A+O$ uitgegeven nieuwsbrief. Daarnaast ontvangen de bedrijven die deelnemen aan het werkgeverspanel bij iedere meting een "bedrijfsfoto". In dit benchmarkinstrument wordt de positie van het eigen bedrijf vergeleken met het algemene beeld van de bedrijfstak.

Behalve door de auteurs is er bij het Researchcentrum voor Onderwijs en Arbeidsmarkt (ROA) aan dit rapport meegewerkt door Sander Dijksman. We willen graag de leden van de regiecommissie Metalektro bedanken voor hun constructieve commentaar tijdens het gehele proces: Hilde ter Doest (Stichting $A+O$ ), Rien Smit (FME-CWM), Patricia Faber (FNV bondgenoten), Ivo Kuijpers en Quirien van Ojen (Orbis Arbeid en Sociale Zekerheid BV) en Maarten Brouwer (CentERdata). Het veldwerk voor het werkgeverspanel Metalektro is uitgevoerd door Maarten Brouwer, Martijn van de Locht en Vera Toepoel van CentERdata. Elly Schotmans (FME-CWM) was behulpzaam bij het opzoeken van achtergrondgegevens van bedrijven. Ten slotte bedanken we Klaas Roskam (Draka), Bert Jacques (Siemens Nederland) en Jan Rozema (Polynorm NV) voor het testen van de vragenlijsten. 


\section{Managementsamenvatting}

De conjuncturele dip

De Nederlandse economie bevindt zich nog steeds in een stevige recessie, die duidelijk dieper is dan de recessie in het begin van de jaren negentig. Een sterk conjunctuurgevoelige sector als de Metalektro-industrie heeft hier de afgelopen jaren dan ook flink van te lijden gehad. Met name in de elektrotechnische industrie was er sprake van een sterke terugval van het afzetvolume, vooral vanwege de crisis in de ICT sector en de sterke terugval van de export. Ook de instrumenten en optische industrie en de transportmiddelenindustrie kampten met een daling van de afzet. Het is opmerkelijk dat vooral bij veel kleinere bedrijven de afgelopen jaren de afzet daalde.

De meeste bedrijven in de Metalektro zijn echter weer wat optimistischer over de afzetgroei in 2004. Daarbij verwachten de bedrijven in de basismetaal en de transportmiddelenindustrie de hoogste afzetgroei. De verwachte afzetgroei in de Metalektro moet zoals gebruikelijk vooral van de exportgroei komen $(+4,5 \%)$, al verwachten de bedrijven ook een lichte groei van de vraag op de binnenlandse afzetmarkt $(+2 \%)$. Dit optimisme stemt overeen met de verwachtingen van de bedrijven in andere Europese landen. Zo verwachten de Duitse Metalektrobedrijven voor 2004 een groei van hun afzetvolume met 2,3\%.

Door de krimp van het productievolume en de voortschrijdende productiviteitsstijging is de werkgelegenheid in de Metalektro de afgelopen jaren flink afgenomen. Het sterkst was de krimp van het personeelsbestand in de elektrotechnische industrie en de transportmiddelenindustrie. De verwachte opleving van de afzet in 2004 zal zich ook nog niet weerspiegelen in het weer aantrekken van de werkgelegenheid. Integendeel, er zal nog duidelijk sprake zijn van het naijleffect van de afgelopen recessiejaren. De productiecapaciteit van de meeste bedrijven is immers nog te groot in verhouding tot de verwachte afzet.

Schommelingen in de afzet blijken dan ook voor een belangrijk deel door de bedrijven zelf te worden opgevangen: overtollig personeel wordt gewoon in dienst gehouden tot de conjunctuur weer aantrekt. Opmerkelijk is ook dat de Metalektrobedrijven bij een sterke groei van de afzet geneigd zijn meer personeel aan te trekken, dan ze bij een even grote daling van de afzet zouden afstoten. Dit illustreert dat het sterk inkrimpen van het personeelsbestand vaak een kostbare zaak is. Hierbij kan men denken aan de directe kosten van ontslag, maar ook aan de kosten die het bedrijf moet maken, wanneer er nieuw personeel moet worden aangetrokken als de conjunctuur weer aantrekt. Hierdoor is er dan ook bij slechts $10 \%$ van de bedrijven die te maken hebben met een dalende afzet, sprake van gedwongen ontslagen. Veel vaker gaan bedrijven over tot herplaatsing van het personeel, terwijl $8 \%$ van de bedrijven ook overgaat tot detachering van het eigen personeel bij andere bedrijven. 


\section{Blijft het werk in Nederland?}

De wereld waarin de Nederlandse Metalektro industrie zich beweegt is de laatste jaren sterk veranderd. Bij alle onderdelen van de 'waardeketen' wordt steeds meer de vraag gesteld wat de beste vestigingsplaats is voor deze activiteiten. Aan de andere kant is er ook een sterke clustervorming in de Metalektro-industrie. Nogal wat bedrijven zijn toeleverancier van grotere bedrijven, die ook in Nederland gevestigd zijn. Deze clustervorming kan het voor bedrijven aantrekkelijk maken om in Nederland gevestigd te blijven. Het betekent echter ook dat er als een belangrijk bedrijf besluit om de productie naar het buitenland te verplaatsen, andere bedrijven kunnen worden meegezogen. Hierdoor kan er een domino-effect optreden. Wat dit betreft is het verontrustend dat de Nederlandse Metalektro-industrie, mede als reactie op de toenemende concurrentie uit deze landen, er steeds meer toe over gaat productiefaciliteiten naar Centraal- en Oost-Europa te verplaatsen. Hierbij gaat het vooral om bedrijven die actief zijn in de metaalproductenindustrie en de machineindustrie.

De veel lagere loonkosten in deze landen vormen voor veel bedrijven de belangrijkste reden voor het verplaatsen van de activiteiten naar deze landen. Andere bedrijven geven ook aan dat de beschikbaarheid van voldoende gekwalificeerd personeel een reden is om zich in deze landen te vestigen. Er zijn echter ook nog steeds voldoende redenen die het voor Metalektrobedrijven aantrekkelijk maken om in Nederland gevestigd te blijven. Drie van de vier bedrijven geeft dan ook aan geen plannen te hebben voor het verplaatsen van de productie. Een drietal factoren draagt er in belangrijke mate toe bij dat deze bedrijven in Nederland willen blijven produceren: het (goede) niveau van het technisch personeel in Nederland, de nabijheid van belangrijke afzetmarkten en de in het verleden gedane investeringen. Voor een kwart van de bedrijven maakt ook de nabijheid van R\&D activiteiten het aantrekkelijk om in Nederland gevestigd te zijn. Deze concurrentievoordelen staan momenteel echter ook onder druk. Het meest duidelijk is dit het geval bij het aanbod van voldoende goed opgeleid technisch personeel. Het is wat dit betreft van groot belang dat het Deltaplan Bèta-techniek een impuls zal weten te geven aan de belangstelling voor de bèta-techniek opleidingen.

Naar een toenemende kwaliteit van de productie

Voor de concurrentiepositie van de Nederlandse Metalektro-industrie is het ook van groot belang dat Nederland zich steeds meer ontwikkelt als een kenniseconomie, die zich richt op het produceren en vermarkten van hoogwaardige producten en diensten. Bedrijven die zich hierop toeleggen concurreren primair op basis van de kwaliteit van hun producten en dienstverlening. Ze moeten beschikken over goed opgeleid personeel dat weet om te gaan met de meest moderne technologie. Hun personeel moet naast vaktechnische kennis en vaardigheden ook beschikken over voldoende communicatieve vaardigheden en oog hebben voor de wensen van de klanten. 
De innovativiteit van de Nederlandse Metalektro-industrie blijkt zich in positieve zin te ontwikkelen. Zo is in 2002 44\% van de bedrijven nieuwe producten gaan produceren. In 2001 was dat nog maar bij $36 \%$ van de bedrijven het geval. Het aanbieden van nieuwe producten leidt bij tweederde van de bedrijven tot een duidelijke upgrading van het niveau van het werk. Opmerkelijk is ook dat productvernieuwing, in tegenstelling tot wat nogal eens wordt gedacht, er bij een kwart van de bedrijven toe heeft geleid dat functies meer specialistisch worden.

Daarnaast voerde één op de drie bedrijven een belangrijke technologische vernieuwing in het productieproces door. In 2001 was dit slechts bij $18 \%$ van de bedrijven het geval. Vooral de kleinere bedrijven zijn op dit punt veel innovatiever geweest. Vernieuwingen van het productieproces leiden meestal tot een productiviteitsstijging, waardoor er met minder mensen meer geproduceerd kan worden. In ruim eenderde van de bedrijven die vernieuwingen in het productieproces doorvoerden is het personeelsbestand dan ook gekrompen. Bij ruim een kwart van de bedrijven heeft de vernieuwing van het productieproces echter juist geleid tot een uitbreiding van het personeel. Ook productieprocesvernieuwingen leiden vaak tot een upgrading van het niveau van het werk en meer specialistische functies.

\section{Het belang van goed inzetbaar personeel}

Voor de concurrentiepositie van de Metalektrobedrijven is het ook belangrijk dat het personeelsbestand flexibel is. Het is daarom niet verrassend dat veel bedrijven gedetacheerd personeel inhuren en ook van hun personeel verwachten dat ze af en toe bereid zijn om over te werken.

Daarnaast moeten bedrijven kunnen beschikken over een goed opgeleid personeelsbestand. Wat dit betreft is het opmerkelijk dat er in de Metalektro nog steeds veel mensen werkzaam zijn die niet beschikken over wat doorgaans wordt aangeduid als een 'startkwalificatie' voor de arbeidsmarkt op MBO-2 niveau. Een aanzienlijk deel van het personeel heeft slechts basisonderwijs of een opleiding op VMBO niveau. Aangenomen mag worden dat deze mensen in de praktijk doorgaans toch voldoende functioneren. Dit wijst er op dat er met name bij deze werknemers in de Metalektro-industrie duidelijk potentieel aanwezig is voor het opzetten van EVC projecten. Gezien de voortschrijdende upgrading van de voor het werk in de Metalektro vereiste competenties, is het van groot belang dat op deze manier de competenties van het personeel transparanter gemaakt worden. Bovendien geeft EVC de betrokkenen vaak een stimulans om aanvullende scholing te gaan volgen.

Ook blijkt dat Metalektrobedrijven de kennis die ze in huis hebben lang niet altijd volledig gebruikten. Vooral de kennis en vaardigheden van ondersteunend personeel en werknemers in functies op het gebied van ontwikkeling en engineering wordt vaak slechts beperkt ingezet. Veel bedrijven zijn zich overigens wel bewust van deze onderbenutting van hun kennispotentieel. Dit blijkt bijvoorbeeld uit het feit dat het gebruik van de kennis van het personeel dat betrokken is bij ontwikkeling en engineering is gestegen. 
Voor de meeste bedrijven is de inzetbaarheid van het technisch personeel van groot belang. Vrijwel alle Metalektrobedrijven geven aan dat ze de inzetbaarheid van het technisch personeel proberen te verhogen. Dat gebeurt zowel door bij- of omscholing, als door het personeel in aanraking te laten komen met nieuwe taken en het stimuleren van functiewisselingen.

Ondanks het grote belang dat men hecht aan een goede inzetbaarheid van het personeel, blijkt dat niet alle bedrijven inzetbaarheid van hun personeel ook daadwerkelijk benutten. Zo geeft meer dan één op de vier bedrijven aan dat zij hun personeel zelden of nooit voor andere taken inzetten. Overigens zijn er op dit punt wel verschillen tussen functiecategorieën. Zo wordt het uitvoerend technisch personeel wel in veel bedrijven ingezet voor taken die niet direct tot hun functie behoren. De benutting van de inzetbaarheid van leidinggevende technici ligt echter wat lager. De overigens in de praktijk beperkte inzetbaarheid van werknemers die betrokken zijn bij ontwikkeling en engineering wordt in de Metalektro het minst benut.

De in-, door- en uitstroom van personeel

In 2002 en 2003 is de totale werkgelegenheid in de Metalektrobedrijven met ruim 14.000 werknemers gedaald. Hoewel de werkgelegenheid ook al in 2002 terugliep, zien we in 2003 een duidelijk neergaande trend: in ieder kwartaal was de werkgelegenheidsdaling groter dan het kwartaal ervoor. De personeelsuitstroom had in 2003 een minder trendmatig verloop: In de eerste helft van 2003 daalde de uitstroom licht; in het derde kwartaal was de uitstroom hoger en in het laatste kwartaal van 2003 was er weer sprake van een daling.

Het valt overigens op dat in het laatste kwartaal van 2003 zowel de instroom als de uitstroom behoorlijk daalden. De instroom is het sterkst gedaald voor uitvoerende technici en ondersteunend personeel. Voor deze functies was de personeelsinstroom in het vierde kwartaal van 2003, in vergelijking met het eerste kwartaal, meer dan gehalveerd. Ook de instroom van hoger opgeleid technisch personeel is in de loop van 2003 duidelijk afgenomen.

Het aandeel van de schoolverlaters in de personeelsinstroom is opmerkelijk laag. De meeste nieuwe werknemers in de Metalektro zijn afkomstig van een ander bedrijf binnen of buiten de Metalektro. Dit weerspiegelt de voorkeur van de bedrijven om bij vacatures werknemers met werkervaring aan te trekken. Deze voorkeur is goed te verklaren: Voor schoolverlaters bedraagt de gemiddelde inwerktijd bijna een jaar, terwijl werknemers met werkervaring gemiddeld slechts 4 maanden inwerktijd nodig hebben om hun nieuwe functie onder de knie te krijgen.

Bijna de helft van de personeelsuitstroom vond plaats door gedwongen ontslag, of het aflopen van een tijdelijk arbeidscontract. Het aandeel van dit onvrijwillig ontslag in de totale personeelsuitstroom is in 2003 , in vergelijking met het jaar daarvoor, met circa 10\%-punt gestegen. Ongeveer een kwart van de werknemers die uitstroomden gingen met (vervroegd) pensioen. De trendmatige stijging van het aandeel van de pensioengangers in de totale personeelsuitstroom heeft zich in 2003 duidelijk 
voortgezet: in 2003 gingen ruim 1.000 werknemers méér met (pre)pensioen dan in het jaar daarvoor. Dit weerspiegelt de voortschrijdende vergrijzing van het personeelsbestand in veel Metalektrobedrijven. Het vrijwillig ontslag is daarentegen in 2003 verder afgenomen. Dit geeft aan dat werknemers in minder goede omstandigheden minder vaak vrijwillig van baan veranderen.

Evenals in 2002, is de instroom van nieuwe werknemers bij alle functiecategorieën in alle kwartalen van 2003 achtergebleven bij de uitstroom. Dit betekent dat de werkgelegenheid in 2003 in alle functiecategorieën is gedaald. Voor de uitvoerende technici was de daling in de werkgelegenheid het sterkst.

Het is opmerkelijk dat er in 2003 binnen de bedrijven veel meer personeel is doorgestroomd naar een andere functie dan in 2002. De totale doorstroom in 2003 is bijna verdubbeld tot meer dan 3.000 medewerkers. Het grootste deel van de doorstroom heeft betrekking op personeel dat doorstroomde naar een andere technische functie op een gelijk of hoger niveau. Deze toename zal voor een groot deel het gevolg zijn van de herplaatsing van personeel in bedrijven die te kampen hebben met een dalende afzet. De toegenomen horizontale en verticale doorstroom kan overigens de employability van het personeel verder vergroten.

\section{Krimpende werkgelegenheid en toch vacatures}

In 2003 is de werkgelegenheid in de helft van de Metalektrobedrijven afgenomen. De daling in de werkgelegenheid heeft vooral betrekking op de uitvoerende technische beroepen. Bedrijven met een krimpende werkgelegenheid, reageren hier meestal op door een vacaturestop af te kondigen en tijdelijke contracten niet te verlengen. Ook worden werknemers vaak naar andere functies binnen het bedrijf overgeplaatst. Ruim een kwart van de Metalektrobedrijven met een krimpende werkgelegenheid gaat over tot gedwongen ontslagen.

Ondanks de krimpende werkgelegenheid, staan er nog rond de 3.000 vacatures in de Metalektro open. Wel is het totaal aantal vacatures in de eerste drie kwartalen van 2003 afgenomen. In het vierde kwartaal is er echter weer sprake van een lichte opleving van het aantal vacatures. Met name voor het leidinggevend technisch personeel trekt het aantal vacatures weer duidelijk aan. Opvallend is dat bij ruim een kwart van de bedrijven met een krimpende werkgelegenheid, tegelijkertijd ook vacatures openstonden. Omdat in het merendeel van deze bedrijven het reguliere personeelsverloop groter is dan de krimp, hebben de openstaande vacatures met name betrekking op de vervangingsvraag. Alleen in het laatste kwartaal van 2003 is dit niet het geval. Hieruit valt af te leiden dat bedrijven in die periode behoefte hadden aan personeel met andere kennis en vaardigheden dan het personeel dat ze in dienst hebben.

De meeste vacatures in de Metalektro hebben betrekking op functies voor technici van MBO niveau of hoger. Het aantal vacatures voor laag- en ongeschoold technisch personeel is in 2003 verder gedaald. Dit illustreert dat er in de Metalektro steeds minder vraag is naar laaggeschoolde arbeid, als gevolg van de upgrading van 
kwalificatie-eisen, vanwege technologische of organisatorische veranderingen van het productieproces, of omdat bedrijven dit soort werkzaamheden steeds meer uitbesteden naar lagelonenlanden.

Het is opmerkelijk dat bedrijven hun vacatures voor technisch personeel niet sneller kunnen opvullen nu de arbeidsmarkt minder krap geworden is. In tegendeel, de bedrijven in de Metalektro hebben vaker met moeilijk vervulbare vacatures te kampen dan in 2002. Bijna de helft van de vacatures heeft betrekking op functies waarvoor het aanbod van geschikt personeel tekort schiet. Eén op de tien bedrijven geeft aan veel problemen te hebben met het vinden van technisch personeel. Het is echter opvallend dat de bedrijven met veel vacatures minder problemen hebben bij het vinden van geschikt technisch personeel. Waarschijnlijk besteden deze bedrijven meer aandacht aan hun wervingsbeleid, waardoor men minder problemen ondervindt bij het vinden van geschikt personeel.

In de huidige ruimere arbeidsmarkt blijken bedrijven bij het aantrekken van nieuw personeel ook duidelijk minder vaak concessies te doen. Zo gaan bedrijven er in 2003 minder vaak dan in 2002 toe over om mensen met minder ervaring, een lager opleidingsniveau of een andere opleidingsrichting aan te stellen, dan men aanvankelijk beoogde. Ook gaan bedrijven minder vaak over tot het bieden van hogere salarissen of het aanbieden van betere, CAO overstijgende arbeidsvoorwaarden.

\section{De noodzaak van scholing}

Scholing is in de Metalektro van groot belang. Het overgrote deel van de Metalektrobedrijven is zich dan ook duidelijk bewust van de noodzaak hun personeel voldoende te scholen. Deze noodzaak is wellicht het meest evident wanneer er sprake is van tekorten aan bepaalde kennis of vaardigheden. In het algemeen is het goed gesteld met de competenties van het technisch personeel in de Metalektro. Het is echter wel verontrustend dat één op de tien bedrijven aangeeft dat hun technisch personeel met een groot tekort aan vaktechnische vaardigheden kampt. Een ander punt van zorg is dat relatief veel bedrijven aangeven dat het bij hun technisch personeel de competenties op het terrein van 'communicatie', 'probleemoplossend vermogen', en 'leidinggeven' tekortschieten. Deze problemen worden verergerd door het toenemend belang dat de bedrijven hechten aan het probleemoplossend vermogen en de communicatieve vaardigheden van hun personeel.

Competentietekorten kunnen onder andere ontstaan wanneer bedrijven over gaan tot de productie van nieuwe producten of hun productieproces innoveren. Om op deze ontwikkelingen in te spelen, staan bedrijven twee opties ter beschikking, die men zou kunnen typeren als een make or buy beslissing. De meeste Metalektrobedrijven kiezen daarbij voor de 'make' strategie. Dit betekent dat bedrijven hun personeel scholing laten volgen waarin men zich de vereiste kennis en vaardigheden eigen kan maken. Veel minder bedrijven hanteren de 'buy' strategie: het aantrekken van nieuw adequaat gekwalificeerd personeel. Bedrijven hanteren deze buy strategie met name wanneer technische functies in het bedrijf steeds specialistischer worden. Kennelijk 
is er dan behoefte aan specialisten die men niet in voldoende mate in huis heeft en ook niet door aanvullende training intern kan ontwikkelen. Ten slotte neemt minder dan één op de tien bedrijven helemaal geen maatregelen om met technologische en organisatorische veranderingen in het bedrijf om te gaan. Deze bedrijven kiezen kennelijk voor een 'laissez-faire' beleid. Waarschijnlijk heeft dit op de korte termijn geen al te grote effecten voor de concurrentiepositie het bedrijf. Op de wat langere termijn kunnen er echter wel problemen ontstaan en zal het voor deze bedrijven moeilijk zijn om zich op hun afzetmarkten te kunnen handhaven.

In bijna $80 \%$ van de bedrijven volgt het technisch personeel interne cursussen. Externe cursussen worden in nog meer bedrijven gevolgd. Deze percentages zijn ongeveer gelijk aan die in 2002, toen het in veel bedrijven economisch gezien nog wat beter ging. Opvallend in dit opzicht is dat bedrijven die met een krimpende werkgelegenheid te maken hebben, even vaak cursussen aan hun technisch personeel aanbieden dan bedrijven met een stabiele of zelfs stijgende werkgelegenheid. Cursussen op het gebied van vaktechnische vaardigheden zijn het meest populair. Daarnaast worden er veel IT-cursussen en cursussen gericht op het vergroten van het probleemoplossend vermogen gevolgd.

Tweederde van de Metalektrobedrijven geeft aan dat er factoren zijn die de cursusparticipatie van het technisch personeel belemmeren. Vooral het kostenaspect is een grotere belemmering gaan vormen. Gemiddeld wordt er $€ 2.100$,- per getrainde werknemer aan cursussen uitgegeven. Ook is het soms een belemmering dat het volgen van een cursus veel tijd kost, of dat de cursus op een ongunstig tijdstip plaatsvindt. Andere bedrijven geven aan dat hun personeel soms helemaal niet geïnteresseerd is in het volgen van een cursus. Met name in de kleine bedrijven is er vaak geen goede opleidingscultuur.

Veel bedrijven in de Metalektro maken gebruik van verschillende regelingen en subsidies om de scholingskosten te beperken. $85 \%$ van de bedrijven maakt gebruik van de scholingsaftrek van de fiscus. $60 \%$ heeft subsidies van de Stichting $A+O$ ontvangen. De subsidies van het Europees Sociaal Fonds (ESF) concentreren zich bij een veel kleinere groep bedrijven. Slechts $5 \%$ van de Metalektro bedrijven profiteert van deze subsidies. Het blijkt dat kleine bedrijven minder vaak van subsidies gebruik maken dan grote bedrijven. Wellicht beschikken zij niet over de juiste resources in de vorm van goede informatie en beschikbaar personeel om hun aanvragen in te dienen. Daarnaast loont het aanvragen van subsidies ook meer voor grote bedrijven, omdat het meestal om grotere bedragen gaat. Bedrijven die subsidies van de Stichting $A+O$ ontvangen, bekostigen hiermee ongeveer $20 \%$ van hun totale scholingskosten. Hetzelfde geldt voor bedrijven die subsidies van het ESF verkrijgen. $\mathrm{De} A+O$ en $E S F$ subsidies blijken overigens met name de externe cursusparticipatie te bevorderen.

Bedrijven kunnen de scholing van hun werknemers ook bevorderen door een gericht HRM beleid te voeren. Zo kan de cursusparticipatie op bedrijfsniveau vergroot worden door de inzet van een bedrijfsopleidingsplan en door carrièreplanning. Wanneer een bedrijf eenmaal aan scholing doet, kan de deelname aan interne 
cursussen binnen het bedrijf toenemen als er scholingsgesprekken plaatsvinden, persoonlijke ontwikkelingsplannen (POP's) worden opgesteld, en er aandacht is voor carrièreplanning en functieroulatie, of wanneer er gebruik gemaakt wordt van een competentie- of vaardighedenmatrix. Carrièreplanning is overigens ook een belangrijk instrument om meer technische werknemers aan externe cursussen te laten deelnemen.

\section{Het belang van Human Resource Management}

De complexe structuur van veel productieprocessen in de Metalektrobedrijven en de sterke internationale concurrentie vereisen een optimaal inzetbaar personeelsbestand, waarvan de competenties up-to-date zijn. Daarom is het niet verrassend dat het Human Resource Management (HRM) tegenwoordig in veel Metalektrobedrijven een centrale plaats inneemt in het strategisch beleid. Een gedegen HRM-beleid heeft immers op vele terreinen aantoonbare voordelen. Zo zorgt het opleiden van de werknemers er voor dat het bedrijf kan beschikken over de kennis en vaardigheden die nodig zijn om optimaal profijt te trekken van de mogelijkheden die technologische en organisatorische innovaties bieden om de concurrentiepositie van het bedrijf te versterken. Een goed HRM beleid draagt bovendien bij aan het behoud van personeel; het zogenaamde "binden en boeien". Instrumenten zoals carrièreplanning, persoonlijke ontwikkelingsplannen en functieroulatie zorgen ervoor dat werknemers de kans krijgen om zich tijdens hun loopbaan verder te ontwikkelen en door te groeien. Dergelijke instrumenten kunnen ook belangrijk zijn bij de werving van nieuw personeel, doordat bedrijven die veel aandacht besteden aan het HRM-beleid tevens aantrekkelijke werkgevers zijn.

Het overgrote deel van de Metalektrobedrijven blijkt ook in mindere goede economische omstandigheden veel aandacht te besteden aan hun HRM-beleid. Wat betreft de concrete invulling van het HRM-beleid blijkt dat er in bijna zeven op de tien bedrijven naast geregeld werkoverleg, ook functioneringsgesprekken en beoordelingsgesprekken worden gevoerd. Ook het aanbieden van opleidingsfaciliteiten en het opstellen van bedrijfsopleidingsplannen is populair. Hoewel nog weinig bedrijven EVC toepassen, is het percentage bedrijven dat dit doet wel verdubbeld naar $4 \%$ in 2003. Een opvallende ontwikkeling is echter wel dat de evaluatie en planning van scholingsactiviteiten door middel van scholingsgesprekken sterk is toegenomen, terwijl minder bedrijven nog aan al hun technische werknemers opleidingsfaciliteiten aanbieden. Blijkbaar wordt er meer aandacht besteed aan het vinden van passende scholing en worden de investeringen in opleidingen ook beter geëvalueerd. De scholing kan daardoor gerichter plaatsvinden en ook beter worden gerelateerd aan de ondernemingsdoelstellingen. Deze professionalisering van het HRM beleid zal het rendement van het opleidingsbeleid waarschijnlijk vergroten.

Hoe goed het HRM-beleid van de bedrijven ook is, de inspanningen gericht op het inzetten en versterken van het menselijk kapitaal moeten voor een belangrijk deel ook komen van het personeel zelf. Het overgrote deel van de bedrijven vindt dan ook dat er bij de employability van het personeel sprake is van een gedeelde verantwoordelijkheid van de werknemer en het bedrijf. 
De HRM-inspanningen van bedrijven blijken ook een duidelijke invloed te hebben op de inzetbaarheid van het personeel. Zo bevorderen het bedrijfsopleidingenplan, beoordelingsgesprekken en het voeren van geregeld werkoverleg de inzetbaarheid van het uitvoerend technisch personeel. Bij het leidinggevend personeel en de werknemers die betrokken zijn bij ontwikkeling en engineering, wordt de inzetbaarheid vooral vergroot door de aanwezigheid van betere opleidingsfaciliteiten. Daarnaast blijkt dat leidinggevende technici beter inzetbaar zijn wanneer er functioneringsgesprekken gevoerd worden. Het expliciet aan de orde stellen van het functioneren van leidinggevende technici blijkt dus ook een positief effect te hebben op hun inzetbaarheid. Bij het personeel dat betrokken is bij de ontwikkeling en engineering zijn vooral persoonlijk ontwikkelingsplannen (POP's) en functieroulatie van belang voor de inzetbaarheid.

\section{De Metalektro in de toekomst}

In de meeste sectoren van de Nederlandse industrie zal de werkgelegenheid de komende jaren verder krimpen. De werkgelegenheid in de Metalektrosector (inclusief de kleinmetaal) zal naar verwachting tussen 2003 en 2008 verder krimpen met ruim 33.000 werknemers. Dat is bijna $10 \%$ van het huidige personeelsbestand. Voor alle sectoren binnen de Metalektro wordt op de middellange termijn een dergelijke werkgelegenheidskrimp verwacht. Ondanks de dalende werkgelegenheid zijn er echter ook de komende jaren behoorlijk wat baanopeningen voor nieuw personeel te verwachten. Deze baanopeningen zijn grotendeels het gevolg van de vervangingsvraag: de vraag naar nieuwe werknemers die voor het grootste gedeelte het gevolg is van oudere werknemers die de arbeidsmarkt verlaten vanwege hun (pre)pensionering.

Voor 2004 verwacht $40 \%$ van de bedrijven geen problemen bij het vinden van technisch personeel, terwijl slechts $4 \%$ van de bedrijven verwacht dat de problemen zullen toenemen. Vanwege de werkgelegenheidskrimp zal de Metalektro ook op de middellange termijn slechts in beperkte mate geconfronteerd worden met knelpunten in hun personeelsvoorziening. Alleen voor elektromonteurs en medisch instrumentenmakers worden nog grote knelpunten verwacht. Dat vertaalt zich in knelpunten voor drie opleidingstypen, waarvoor de instroom onvoldoende zal zijn om aan de totale vraag te voldoen: MBO elektrotechniek, MBO administratie en logistiek en $\mathrm{HBO}$ elektrotechniek.

Voor veel Metalektrobedrijven is de toekomstige uitstroom van technisch personeel door (pre-)pensionering echter een belangrijk aandachtspunt. Hoewel in iets meer dan de helft van de bedrijven de pensioenuitstroom beperkt blifft tot maximaal $5 \%$ van het huidige personeel, geeft ook bijna $30 \%$ van de bedrijven aan dat 6 tot $10 \%$ van hun personeelsbestand de komende vijf jaar met pensioen zal gaan. Dat levert voor een aantal bedrijven problemen op. Zes procent van de bedrijven voorziet grote problemen, terwijl ongeveer één op de vijf bedrijven aangeeft weliswaar problemen te verwachten, maar er van uit gaat dat deze wel oplosbaar zijn. 
Voor bedrijven die in de toekomst wel problemen bij de vervanging van gepensioneerd technisch personeel verwachten, is het van groot belang daar nu al op in te spelen. Door nu al maatregelen te nemen kunnen de toekomstige problemen in de personeelsvoorziening verlicht of wellicht zelfs opgelost worden. Instrumenten die daarbij veelvuldig gehanteerd worden zijn: het opleiden van het personeel en het bevorderen van taakroulatie om de inzetbaarheid van het personeel te vergroten.

Agenda voor de toekomst

De belangrijkste uitdaging voor het arbeidsmarkt- en personeelsbeleid in de Metalektro zal de komende jaren vooral betrekking hebben op kwalitatieve personeelsproblematiek. Dit om twee redenen:

- de voortschrijdende upgrading van het niveau van het werk;

- de voortschrijdende vergrijzing van het personeelsbestand.

De voortschrijdende vergrijzing van het technisch personeel in de Metalektro heeft in feite twee belangrijke gevolgen. In de eerste plaats betekent het dat de komende jaren het personeelsverloop vanwege pensionering sterk zal toenemen. In de tweede plaats kan het betekenen dat de komende jaren belangrijke ervaringskennis verloren gaat.

Voor de concurrentiepositie van de Nederlandse Metalektro-industrie is het de komende jaren van groot belang dat bedrijven de beschikking hebben over goed opgeleid personeel dat weet om te gaan met de meest moderne technologie. Het verhogen en up-to-date houden van het competentieniveau van het personeel in de Metalektro en het vergroten van hun inzetbaarheid zal bovendien bepalend zijn voor de mate waarin Metalektrobedrijven zich in Nederland zullen (blijven) vestigen.

De toekomstige kwalitatieve personeelsproblematiek geeft de volgende zaken een centrale plaats op de agenda voor de toekomst:

- Initiatieven als het Deltaplan Bèta-techniek, die een impuls zullen moeten geven aan de toekomstige belangstelling voor de bèta-techniek opleidingen.

- $\quad$ EVC projecten die de competenties van het huidige personeel meer transparant kunnen maken en stimuleren dat lager opgeleiden aanvullende scholing gaan volgen die hun inzetbaarheid in de toekomst zal vergroten.

- Blijven investeren in de bij- of omscholing van het personeel en het vergroten van de employability van het personeel.

- Verdere professionalisering van het HRM beleid, waardoor het rendement van het personeelsontwikkelingsbeleid kan worden vergroot.

- Overdracht van ervaringskennis van het oudere naar het jongere personeel, om te voorkomen dat belangrijke ervaringskennis verloren gaat. 


\section{Dynamiek in de Metalektro}

De Metalektrobedrijven hebben de afgelopen jaren flink te lijden gehad onder de economische recessie. Ondanks de meer optimistische verwachtingen voor 2004 zal de werkgelegenheid dit jaar echter nog verder afnemen. Daarnaast speelt de vraag in hoeverre bedrijven overwegen productieactiviteiten te verplaatsen naar het buitenland. Welke factoren zijn nu bepalend om in Nederland te blijven produceren? Van groot belang voor de concurrentiepositie in de Nederlandse Metalektro-industrie is ook de mate waarin bedrijven er in slagen hun innovativiteit te vergroten. Zowel de introductie van nieuwe producten als ook organisatorische vernieuwingen blijken vaak te leiden tot een upgrading van het niveau van het werk. Ook leidt het nogal eens tot meer specialistische functies.

\subsection{De conjuncturele dip}

Hoewel er reeds enig licht aan het eind van de tunnel kan worden bespeurd, bevindt de Nederlandse economie zich nog steeds in een stevige recessie, die duidelijk dieper is dan de recessie in het begin van de jaren negentig. Exporterende bedrijven hebben het moeilijk vanwege de verslechtering van de prijsconcurrentiepositie, terwijl de economische omstandigheden ook weinig prikkels geven om te investeren. ${ }^{1} \mathrm{Na}$ de sterke groei van de economie in de tweede helft van de jaren negentig, begon de groei van de Nederlandse economie vanaf begin 2001 te stagneren. In zowel 2002 als 2003 daalde de productie van de marktsector zelfs met circa 0,75\%. Voor 2004 verwacht het Centraal Planbureau weer een lichte opleving van de economie. Naar verwachting zal de groei in de productie in de marktsector in 2004 weer wat aantrekken tot zo'n 1,25\%. Voor 2005 verwacht het CPB zelfs weer een economische groei van $1,5 \%$.

De werkgelegenheidsontwikkeling volgt de ontwikkeling in de economische bedrijvigheid altijd met enige vertraging. Dit werd nog verstrekt doordat er, toen de recessie inzette, in veel sectoren nog sprake was van een groot aantal openstaande vacatures. Hierdoor groeide de werkgelegenheid in 2001 nog met 1,3\%. Door de krimp van het productievolume en de rationalisatie van de productieprocessen daalde het arbeidsvolume in de marktsector in 2002 met ruim 30.000 arbeidsjaren. In de eerste drie kwartalen van 2003 was er sprake van een verdere daling met maar liefst 66.000 arbeidsjaren. $^{2}$

De Metalektro-industrie is zoals bekend een sterk conjunctuurgevoelige sector. Dit geldt voor vrijwel alle bedrijven in de sector. Tabel 1.1 laat zien dat de helft van de Metalektrobedrijven zelfs aangeeft in sterke mate gevoelig te zijn voor schommelingen in de conjunctuur. Het is dan ook evident dat de Nederlandse Metalektroindustrie flink te lijden heeft van de huidige recessie.

1. Centraal Planbureau (2003), Macro Economische Verkenning 2004, Den Haag

2. CBS (2004), De Nederlandse conjunctuur 2004, aflevering 1, Voorburg/Heerlen. 
Tabel 1.1

Bedrijfsvestiging gevoelig voor conjuncturele schommelingen

\begin{tabular}{lr} 
Conjuncturele schommelingen & $\%$ \\
\hline & \\
In sterke mate & 46 \\
Enigszins & 47 \\
Niet of nauwelijks & 7
\end{tabular}

Bron: ROA/Werkgeverspanel Metalektro 2003

Tabel 1.2 geeft op basis van de FME-CWM Conjunctuurenquête een meer gedetailleerd overzicht van de ontwikkeling van het afzetvolume in de verschillende sectoren binnen de Metalektro in de jaren 2002 en 2003. Ook wordt een beeld gegeven van de verwachte ontwikkelingen voor 2004. De tabel laat zien dat met name de elektrotechnische industrie in de jaren 2002 en 2003 te lijden heeft gehad van een flinke terugval van het afzetvolume, met name als gevolg van de crisis in de ICT sector en de sterke terugval van de export. Ook de instrumenten- en optische industrie kampte met een daling van de afzet. In 2002 daalde de afzet in de metaalproductenindustrie en de transportmiddelenindustrie, maar in deze sectoren trok de afzet in 2003 weer wat aan. De basismetaal kende geen terugval van het afzetvolume, hoewel de groei in 2003 slechts gering was.

Tabel 1.2

Veranderingen in afzetvolume in de verschillende sectoren binnen de Metalektro, 2002-2004

\begin{tabular}{lccc}
\hline Sector & 2002 & 2003 & $\begin{array}{c}2004 \\
\text { (verwachtingen) } \\
\%\end{array}$ \\
& $\%$ & $\%$ & 4,5 \\
Basismetaalindustrie & & 1,0 & 2,5 \\
Metaalproductenindustrie & 5,0 & 2,5 & 3,0 \\
Machine industrie & $-2,0$ & $-0,5$ & 2,0 \\
Elektrotechnische industrie & 0 & $-5,5$ & 2,5 \\
Instrumenten- en optische industrie & $-7,5$ & $-1,0$ & 5,0 \\
Transportmiddelenindustrie & $-0,5$ & 1,0 & \\
\hline
\end{tabular}

Bron: FME-CWM Conjunctuurenquête (2002 en 2003)

Uit de cijfers van het Werkgeverspanel Metalektro blijkt dat bij ongeveer de helft van de bedrijven de omzet is gedaald. Vooral veel kleinere bedrijven hadden de afgelopen jaren met een daling van hun omzet te kampen. Bij maar liefst tweederde van de Metalektrobedrijven met een jaarlijkse omzet van minder dan $€ 10$ miljoen was dit het geval. Van de bedrijven met een jaarlijkse omzet van meer dan $€ 50$ miljoen had slechts $38 \%$ een omzetdaling.

Tabel 1.2 laat ook zien dat de bedrijven in alle sectoren binnen de Metalektro optimistisch zijn over de afzetgroei in 2004. Daarbij verwachten de bedrijven in de basismetaal en de transportmiddelenindustrie de grootste afzetgroei. De verwachte afzetgroei in de Metalektro moet zoals gebruikelijk vooral van een toename van de 
export komen $(+4,5 \%)$, al verwachten de bedrijven ook een lichte groei van de vraag op de binnenlandse afzetmarkten $(+2 \%)$.

Het weer wat meer optimistische beeld van de Nederlandse Metelektrobedrijven over de afzetontwikkeling voor 2004 stemt overeen met de verwachtingen van de bedrijven in de andere Europese landen. ${ }^{3}$ Zo verwachten Duitse Metalektrobedrijven voor 2004 een groei van hun afzetvolume met 2,3\% en Metalektrobedrijven in Frankrijk en het Verenigd Koninkrijk een groei van respectievelijk $1,8 \%$ en $3,3 \%$. Het meest optimistisch is overigens de Zwitserse Metalektro-industrie, die een afzetgroei verwacht van $5,6 \%$.

Door de krimp van het productievolume en de voortschrijdende productiviteitsstijging is de werkgelegenheid in de Metalektro de afgelopen jaren flink afgenomen. De afzetdaling in 2001 heeft daardoor waarschijnlijk nog zijn uitwerking gehad op de werkgelegenheidsontwikkeling in de jaren daarna. Bovendien volgt de werkgelegenheidsontwikkeling altijd met enige vertraging de ontwikkeling van de afzet.

Tabel 1.3

Ontwikkeling personeelsbestand in de verschillende sectoren binnen de Metalektro, 2002-2004

\begin{tabular}{lccc}
\hline Sector & 2002 & 2003 & $\begin{array}{c}2004 \\
\text { (verwachtingen) } \\
\%\end{array}$ \\
& $\%$ & $\%$ & $-2,0$ \\
& & $-3,0$ \\
Basismetaalindustrie & $-3,5$ & $-3,0$ & $-2,0$ \\
Metaalproductenindustrie & $-2,0$ & $-3,0$ & $-5,0$ \\
Machine industrie & 0 & $-4,5$ & 0 \\
Elektrotechnische industrie & $-9,0$ & $-4,5$ & $-2,0$ \\
Instrumenten- en optische industrie & 1,0 & $-2,0$ & $-2,5$ \\
Transportmiddelenindustrie & $-8,5$ & &
\end{tabular}

Bron: FME-CWM Conjunctuurenquête (2002 en 2003)

Uit tabel 1.3 blijkt dat er in 2002, met uitzondering van de machine industrie en de instrumenten- en optische industrie, in de meeste sectoren sprake was van een aanzienlijke daling van de werkgelegenheid. Het sterkst was de krimp van het personeelsbestand in de elektrotechnische industrie en de transportmiddelenindustrie. In 2003 zien we in alle sectoren een (verdere) werkgelegenheidsdaling, uiteenlopend van een daling van $2 \%$ in de instrumenten- en optische industrie tot $4,5 \%$ in de machine-industrie en elektrotechnische industrie.

De tabel laat ook zien dat de verwachte opleving van de afzet zich in 2004 nog niet zal weerspiegelen in het aantrekken van de werkgelegenheid. Integendeel, hier speelt het naijleffect van de afgelopen recessiejaren, omdat bedrijven overtollig personeel in dienst hebben gehouden, is de productiecapaciteit van de meeste bedrijven in 2004 nog te groot is in verhouding tot de verwachte afzet. Met name de

3. Orgalime, European engineering: 2003 still tough but the downturn is bottoming out, News Release No. 03.07, Brussel. 
bedrijven in de elektrotechnische industrie verwachten nog een sterke verdere afname van hun personeelsbestand. Ook de prognoses van het CPB geven aan dat in 2004 de werkgelegenheid in de Metalektro-industrie nog verder zal afnemen. Het CPB verwacht voor 2004 een werkgelegenheidskrimp met 8000 arbeidsplaatsen. ${ }^{4}$

\section{Effecten van de werkgelegenheidstructuur}

Men kan zich afvragen of de recessie ook gevolgen heeft voor de structuur van de werkgelegenheid in de Metalektro. Daarom is aan de bedrijven gevraagd welk effect een sterke daling van de afzet heeft op de werkgelegenheid voor de verschillende functiecategorieën in hun bedrijf. Tabel 1.4 laat zien dat een afname van het afzetvolume met $25 \%$ vooral leidt tot een werkgelegenheidskrimp in de uitvoerende technische functies. Een flinke terugval van de productie heeft daarentegen slechts een zeer gering effect op de werkgelegenheid in de andere beroepscategorieën. Het lijkt er dus op dat werkenden in deze functies, afgezien van bedrijfssluitingen of fusies, doorgaans weinig gevaar lopen om in een recessieperiode hun baan kwijt te raken. De tabel laat ook zien dat een flinke terugval in de afzet zich niet direct weerspiegelt in een even grote krimp van het personeel. Bij een daling van de productie met $25 \%$ krimpt het aantal werkenden namelijk slechts met $14 \%$. Ook is de Metalektrobedrijven gevraagd naar de toename van de werkgelegenheid bij een sterke stijging van de afzet.

Tabel 1.4

Gemiddelde toe- en afname van het personeelsbestand wanneer het afzetvolume met $25 \%$ daalt of stijgt

\begin{tabular}{|c|c|c|}
\hline Beroepscategorie & $\begin{array}{c}\text { Productie daalt } \\
\text { met } 25 \%\end{array}$ & $\begin{array}{c}\text { Productie stijgt } \\
\text { met } 25 \%\end{array}$ \\
\hline
\end{tabular}

$\begin{array}{lcc}\text { Uitvoerende technische functies } & - & ++ \\ \text { Leidinggevende technische functies } & - & + \\ \text { Ontwikkeling en engineering } & - & + \\ \text { Hoger management } & - & + \\ \text { Ondersteunende, administratieve of commerciële functies } & -14 \% & +19 \% \\ \text { Totale personeel } & -1 \%\end{array}$

Bron: ROA/Werkgeverspanel Metalektro 2003

$--=$ sterk dalend, $-=$ dalend, $++=$ sterk stijgend, $+=$ stijgend

Duidelijk blijkt verder dat als de productiegroei sterk aantrekt de werkgelegenheid veel minder groeit. De beperkte invloed van de ontwikkeling van de afzet op de omvang van het personeelsbestand geeft aan dat schommelingen in de afzet voor een belangrijk deel door het bedrijf zelf worden opgevangen. Overtollig personeel wordt gewoon in dienst gehouden tot de conjunctuur weer aantrekt. Opmerkelijk is overigens ook dat de bedrijven bij een sterke groei van de afzet geneigd zijn meer personeel aan te trekken, dan ze bij een even grote daling van de afzet zouden

4. CPB (2003), In focus: The metal-electro industry in the Netherlands 2002-2004, CPB Memorandum nr. 66, Den Haag.

4 
afstoten. Dit illustreert dat het sterk inkrimpen van het personeelsbestand vaak een kostbare zaak is. Daarbij kan men denken aan de directe kosten van ontslag, maar ook aan de kosten die het bedrijf moet maken als er weer nieuw personeel moet worden aangetrokken wanneer de conjunctuur weer aantrekt.

\section{Met welke problemen kampen de bedrijven in de Metalektro?}

Voor ruim de helft van de bedrijven in de Metalektro is de minder gunstige economische situatie een van de belangrijkste problemen waarmee de organisatie wordt geconfronteerd (zie tabel 1.5). Voor $48 \%$ van de bedrijven is de concurrentie binnen de eigen branche een groot probleem. Een kwart van de bedrijven worstelt daarbij met de hoge personeelskosten. Het is opvallend dat in 2003 veel minder bedrijven grote problemen hadden op het terrein van de automatisering dan in 2002. Ook zaken als kwaliteitszorg, interne communicatie, financiering en logistiek werden in 2003 door veel minder bedrijven als problematisch bestempeld dan in 2002 . Daarentegen waren er in 2003 weer meer bedrijven met problemen op het terrein van milieuaangelegenheden.

Tabel 1.5

Belangrijkste problemen voor bedrijven in de Metalektro in 2002 en $2003^{*}$

\begin{tabular}{lrr} 
Probleem & $\begin{array}{r}2002 \\
\%\end{array}$ & $\begin{array}{r}2003 \\
\%\end{array}$ \\
\hline De minder goede economische omstandigheden & - & 51 \\
Concurrentie binnen de branche & 60 & 48 \\
Kosten van personeel & 43 & 25 \\
Werving van geschikt personeel & 41 & 13 \\
Automatisering & 24 & 8 \\
Omzet & 21 & 20 \\
Kwaliteitszorg & 13 & 6 \\
Interne communicatie & 13 & 4 \\
Financiering & 10 & 5 \\
Logistiek & 10 & 6 \\
Arbozaken & 3 & 4 \\
(EU)wetgeving & 2 & 0 \\
Milieuaangelegenheden & 1 & 9
\end{tabular}

- geen informatie beschikbaar

* De verschillende percentages staan los van elkaar en hoeven dus niet op te tellen tot $100 \%$

Bron: ROA/Werkgeverspanel Metalektro 2003

Tabel 1.6 laat zien dat bij bijna de helft van de bedrijven die te kampen hebben met een daling van de omzet, de werkgelegenheid krimpt. Het aantal lagere functies neemt daarbij het sterkst af. Bij slechts $10 \%$ van de bedrijven die te maken hebben met een dalende afzet, is er sprake van gedwongen ontslagen. Er is wat dat betreft vaker sprake van een herplaatsing van het personeel, terwijl $8 \%$ van de bedrijven overgaat tot detachering van het eigen personeel bij andere bedrijven. Bij één op de tien bedrijven met een dalende omzet verandert ook de inhoud van functies. Meestal gaat het daarbij om een verbreding van functies. Het is overigens opmerkelijk dat bij 
de bedrijven met een stijgende omzet de inhoud van functies veel vaker verandert. Bij bijna de helft van deze bedrijven worden functies breder ingevuld.

Tabel 1.6

Gevolgen van een omzetdaling voor het personeelsbestand in $2003^{*}$

Gevolg

Inkrimping van het personeelsbestand

Toename van het aantal lagere technische functies

Toename van het aantal hogere technische functies

Gedwongen ontslagen

Afname van het aantal lagere technische functies

Afname van het aantal hogere technische functies

Herplaatsing van personeel

Detachering van het eigen personee

Functies worden meer specialistisch

Functies worden breder

Om- en bijscholing van personeel

Geen direct gevolg

* De verschillende percentages staan los van elkaar en hoeven dus niet op te tellen tot $100 \%$ Bron: ROA/Werkgeverspanel Metalektro 2003

\subsection{Blijft het werk in Nederland?}

De wereld waarin de Nederlandse Metalektro-industrie zich beweegt is de laatste jaren sterk veranderd. De invloed van het globaliseringsproces wordt steeds duidelijker: de invoering van de Europese markt, de aanstaande uitbreiding van de Europese Unie met 10 nieuwe lidstaten en de snelle ontwikkeling van China en andere Aziatische landen. Daarnaast speelt ook de aangescherpte concurrentie met de Verenigde Staten, die haar metaalindustrie door een protectionistisch beleid probeert af te schermen tegen Europese importen en bovendien momenteel profiteert van de lage dollarkoers.

Evenals de andere landen in de Europese Unie, profileert Nederland zich steeds meer als een kenniseconomie, die zich richt op het produceren en vermarkten van hoogwaardige en dus kennisintensieve producten en diensten. Dit is zeker ook in de Metalektro het geval. Dit blijkt duidelijk uit de toenemende complexiteit van de 'waardeketen' die zich uitstrekt van R\&D tot after sales services. In toenemende mate wordt bij alle onderdelen van deze waardeketen de vraag gesteld wat de beste vestigingsplaats is voor deze activiteiten. Vanuit Nederlands perspectief roept dit de vraag op in hoeverre het werk in de Metalektro-industrie in de toekomst in Nederland zal blijven.

Uit het Werkgeverspanel Metalektro blijkt dat ruim 40\% van de bedrijven vooralsnog hun belangrijkste concurrent in Nederland heeft (zie figuur 1.1). Hieruit mag echter niet worden afgeleid dat deze bedrijven zich in de luwte van het globaliseringsproces bevinden. De onderlinge concurrentie tussen Nederlandse bedrijven is immers in belangrijke mate het gevolg van de sterke clustervorming in de Metalektro, waarin 
nogal wat bedrijven toeleverancier zijn van grotere bedrijven die ook in Nederland gevestigd zijn.

Figuur 1.1

Vestigingsplaats van de belangrijkste concurrent in 2002 en 2003

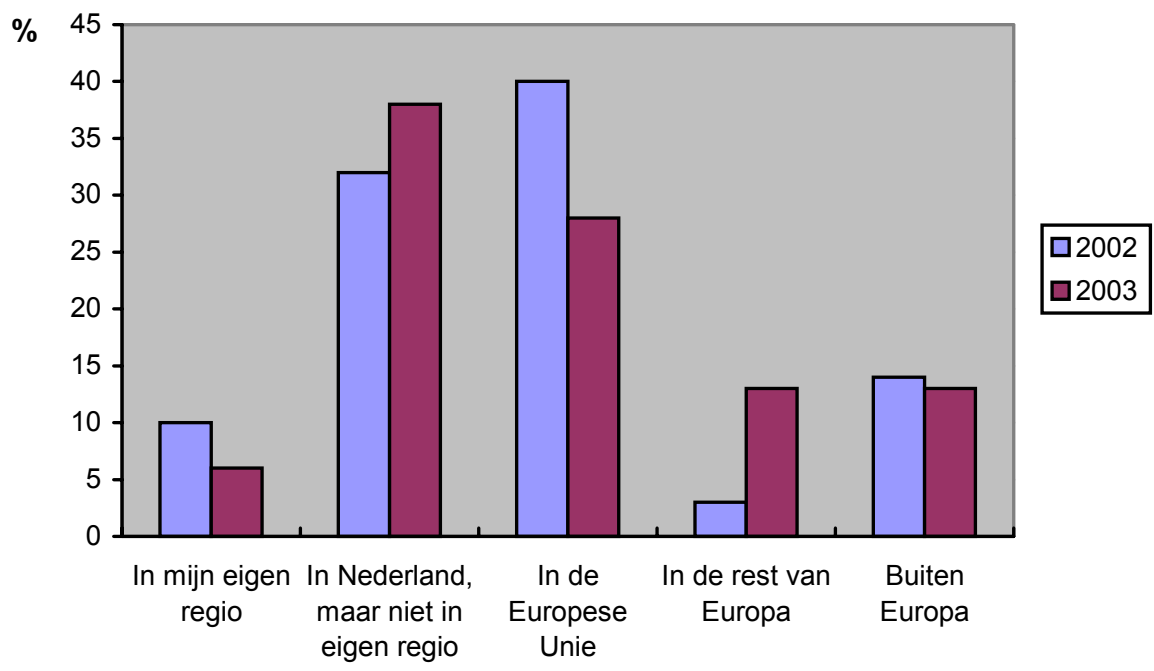

Bron: ROA/Werkgeverspanel Metalektro 2002 en 2003

Aan de ene kant betekent deze clustering dat het voor veel Metalektrobedrijven aantrekkelijk is om in Nederland gevestigd te blijven. Aan de andere kant betekent het ook dat er een domino-effect kan optreden, als een belangrijk bedrijf besluit om de productie naar het buitenland te verplaatsen.

Het is ook opmerkelijk dat een afnemend aantal bedrijven hun belangrijkste concurrent binnen de Europese Unie heeft zitten. De concurrentie verplaatst zich wat dat betreft duidelijk van de landen binnen de Europese Unie naar de Centraal en Oost-Europese landen, die op het moment van de enquête nog geen deel uitmaakten van de Europese Unie. Wanneer deze landen, die zich kenmerken door een relatief laag loonniveau, medio 2004 tot de Europese Unie toetreden, dan zal dit ongetwijfeld betekenen dat de concurrentie met de Metalektrobedrijven uit deze landen nog verder zal aanscherpen. Van ruim 10\% van de Metalektrobedrijven is de belangrijkste concurrent buiten Europa gevestigd. Hierbij gaat het met name om de concurrentie die Nederlandse bedrijven ondervinden van Amerikaanse bedrijven en bedrijven uit het Verre Oosten.

De vereniging FME-CWM heeft recentelijk in samenwerking met het Ministerie van Economische Zaken onderzoek gedaan naar de verplaatsing van productiefaciliteiten naar Centraal- en Oost-Europa. ${ }^{5}$ Uit dit onderzoek komt naar voren dat de Neder-

5. Vereniging FME-CWM/Ministerie van Economische Zaken (2003), Verplaatsing productiefaciliteiten naar Centraal- en Oost-Europa, Zoetermeer/Den Haag. 
landse Metalektro-industrie er steeds meer toe over gaat productiefaciliteiten naar Centraal- en Oost-Europa te verplaatsen, mede als reactie op de toenemende concurrentie uit deze landen.

De nieuwe EU toetredingslanden Tsjechië, Polen en Slowakije zijn de meest populaire vestigingslanden. Van de bedrijven die aan de FME-CWM enquête hebben deelgenomen heeft $11 \%$ reeds een productievestiging in Centraal- of Oost-Europa. Daarbij gaat het vooral om bedrijven die actief zijn in de metaalproductenindustrie en de machine-industrie. Het merendeel van de productievestigingen van deze bedrijven in Centraal- en Oost-Europa is overigens (nog) relatief klein. Een even grote groep bedrijven is van plan om in de komende vijf jaar ook een productievestiging in Centraal- of Oost-Europa op te richten. Ruim driekwart van de bedrijven heeft daarentegen geen plannen in die richting.

De veel lagere loonkosten vormen voor veel bedrijven de belangrijkste reden voor het verplaatsen van activiteiten naar Centraal- en Oost-Europa. Bedrijven verwachten dat deze kostenvoordelen zeker een jaar of tien groot blijven. Andere bedrijven geven aan dat de beschikbaarheid van voldoende gekwalificeerd personeel een reden was om zich in deze landen te vestigen. Deze bedrijven verwachten dat met name de seriematige productie de komende jaren vaker naar Centraal- en OostEuropa zal worden verplaatst. Dit zou er toe kunnen leiden dat in Nederland zogenaamde "kop-staart bedrijven" ontstaan, die zich concentreren op engineering, R\&D, assemblage, marketing en sales.

Betekent dit nu dat de Metalektro in Nederland sterk zal afbrokkelen? Dit hoeft zeker niet het geval te zijn. Tabel 1.7 laat zien welke factoren voor Metalektrobedrijven bepalend zijn om in Nederland te blijven produceren. Een drietal factoren springt daarbij naar voren:

- het (goede) niveau van het technisch personeel in Nederland,

- de nabijheid van belangrijke afzetmarkten; en

- de in het verleden gedane investeringen.

Tabel 1.7

Factoren die de productie in Nederland bevorderen *

Factor

Niveau van het technisch personeel

Nabijheid van afzetmarkt(en)

In verleden gedane investeringen

Nabijheid van R\&D

Infrastructurele voorzieningen

Productieproces is weinig arbeidsintensief

Economische vestigingsbeleid

${ }^{*}$ De verschillende percentages staan los van elkaar en hoeven dus niet op te tellen tot $100 \%$ Bron: ROA/Werkgeverspanel Metalektro 2003

Voor een kwart van de bedrijven maakt ook de nabijheid van R\&D activiteiten het aantrekkelijk om in Nederland gevestigd te zijn. De infrastructurele voorzieningen in ons land zijn daarentegen slechts voor één op de zes bedrijven een reden van 8 
belang. Al met al zijn er nog steeds voldoende redenen die het voor Metalektrobedrijven aantrekkelijk maken om in Nederland gevestigd te blijven. Aan de andere kant staan de huidige concurrentievoordelen momenteel ook onder druk. Het meest duidelijk is dit het geval bij het aanbod van voldoende goed opgeleid technisch personeel. Steeds minder havo- en vwo leerlingen kiezen voor het profiel Natuur en Techniek, terwijl ook de instroom van jongeren in het technisch beroepsonderwijs en wetenschappelijk onderwijs steeds verder afneemt. ${ }^{6}$ Het is derhalve van groot belang voor de internationale concurrentiepositie van de Nederlandse Metalektro-industrie dat initiatieven als het Deltaplan Bèta-techniek een impuls zullen weten te geven aan de belangstelling voor Bèta-techniek opleidingen. ${ }^{7}$ Naast een langetermijn beleid gericht op het vergroten van de belangstelling voor techniek en innovatie en het verder verbeteren van de kwaliteit van het wiskunde en techniek onderwijs, zal het beleid zich ook meer moeten richten op het vergroten van de belangstelling voor Bèta/techniek bij specifieke doelgroepen, zoals meisjes die goede cijfers halen voor wiskunde en natuur- en scheikunde. ${ }^{8}$

\subsection{Naar een toenemende kwaliteit van de productie}

Voor de concurrentiepositie van de Nederlandse Metalektro-industrie is het van groot belang dat Nederland zich steeds meer ontwikkelt als een kenniseconomie, die zich richt op het produceren en vermarkten van hoogwaardige, kennisintensieve, producten en diensten. Bedrijven die zich hierop toeleggen concurreren primair op basis van de kwaliteit van hun producten en dienstverlening. Ze moeten beschikken over goed opgeleid personeel dat weet om te gaan met de meest moderne technologie. Naast vaktechnische kennis en vaardigheden moet hun personeel ook beschikken over voldoende communicatieve vaardigheden en oog hebben voor de wensen van de klanten. Om hun concurrentiepositie te kunnen handhaven is het voor kennisintensieve bedrijven bovendien van groot belang om hun producten en productieprocessen voortdurend te innoveren. Om volop gebruik te kunnen maken van de toenemende mogelijkheden die informatie- en communicatietechnologie bieden zullen deze bedrijven bovendien zeer alert moeten zijn in het realiseren van organisatorische innovaties. Daarbij gaat het zowel om nieuwe bedrijfsinterne organisatievormen als om logistieke innovaties en nieuwe marketingconcepten. Innovatieve bedrijven kunnen dit alleen realiseren wanneer ze de beschikking hebben over personeel dat met deze ontwikkelingen kan meegaan en bereid is zich bij te scholen wanneer dat nodig is.

\section{Productvernieuwing}

Hoe staat het nu met de innovativiteit van de Nederlandse Metalektro-industrie? Uit het Werkgeverspanel Metalektro blijkt dat in 2002 44\% van de bedrijven nieuwe

6. Zie Axis/CWI (2003), Techniekmonitor 2003, Nijmegen.

7. Ministeries van SZW, EZ, en OCW (2004), $\Delta$-plan ß-techniek Actieplan voor de aanpak van tekorten aan bèta's en technici, Den Haag.

8. Zie A. de Grip en E. Willems, Youngsters and Technology (2003), Research Policy, Vol. 32, 2003, pp. 1771-1871. 
producten is gaan produceren. In 2001 was dat nog slechts bij $36 \%$ van de bedrijven het geval.

Tabel 1.8

Productvernieuwing in $2002^{*}$

Productvernieuwing

Nieuwe producten (nieuw voor Nederlandse markt)

Nieuwe producten (nieuw voor buitenlandse markt)

Nieuwe producten (niet nieuw voor Nederlandse markt)

Nieuwe producten (niet nieuw voor buitenlandse markt)

Producten uit pakket verwijderd*

Geen veranderingen in productlijn

* Deze bedrijven hebben ook allemaal nieuwe producten geïntroduceerd Bron: ROA/Werkgeverspanel Metalektro 2003

Bij een kwart van de bedrijven hadden de nieuwe producten betrekking op producten die geheel nieuw waren voor de (buitenlandse of Nederlandse) afzetmarkt waarop de desbetreffende bedrijven actief zijn. Bij $56 \%$ van de bedrijven zijn daarentegen geen nieuwe producten geïntroduceerd. Men kan zich afvragen of deze bedrijven voldoende investeren in hun innovativiteit. Ook AXIS, het Nationaal Platform voor Natuur en Techniek, wijst erop dat in veel industriële branches een deel van de bedrijven te weinig innovatief is. Volgens AXIS volgt circa $40 \%$ van de bedrijven in onvoldoende mate de innovaties, die andere bedrijven in hun branche doorvoeren. ${ }^{9}$

Welke gevolgen heeft deze productvernieuwing nu gehad voor het personeel? Tabel 1.9 laat zien dat het aanbieden van nieuwe producten niet alleen vaak leidt tot een tijdelijke of permanente uitbreiding van het personeel, maar vooral ook leidt tot een upgrading van het niveau van het werk. Bijna één op de vijf bedrijven die een productvernieuwing introduceerde geeft immers aan dat dit heeft geleid tot een toename van de werkgelegenheid in de hogere technische functies, terwij $10 \%$ aangeeft dat het de werkgelegenheid in de lagere technische functies is afgenomen.

Opmerkelijk is ook dat productvernieuwing, in tegenstelling tot wat nogal eens wordt gedacht, er bij $7 \%$ van de bedrijven toe heeft geleid dat functies meer specialistisch worden, terwijl er bij slechts $3 \%$ van de bedrijven sprake is van functieverbreding. $11 \%$ van de bedrijven met productinnovaties speelt op de upgrading van de vereiste kennis en vaardigheden in door bij- of omscholing van het personeel. Daarentegen geeft slechts $4 \%$ van de bedrijven aan dat de productvernieuwing heeft geleid tot gedwongen ontslagen. 
Technologische vernieuwing

Tabel 1.9

Gevolgen van productinnovaties voor het personeelsbestand*

Gevolg

Tijdelijke uitbreiding van personeel

Permanente uitbreiding van personeel

Toename van het aantal lagere technische functies
Toename van het aantal hogere technische functies

Inkrimping van het personeelsbestand

Gedwongen ontslagen

Afname van het aantal lagere technische functies

Afname van het aantal hogere technische functies

Herplaatsing van personeel

Functies worden meer specialistisch

Functies worden breder

Om- en bijscholing van personeel

Geen direct gevolg

* De verschillende percentages staan los van elkaar en hoeven dus niet op te tellen tot $100 \%$ Bron: ROA/Werkgeverspanel Metalektro 2003

In het werkgeverspanel Metalektro is ook gevraagd of bedrijven in 2002 een belangrijke technologische vernieuwing in hun productieproces hebben geïntroduceerd. Hierbij gaat het om robotisering, verdergaande automatisering, of het inzetten van nieuwe machines of productielijnen. Tabel 1.10 laat zien dat in 2002 veel meer bedrijven dergelijke vernieuwingen hebben doorgevoerd dan in 2001. Eén op de drie bedrijven voerde in 2002 een belangrijke technologische vernieuwing in het productieproces door. In 2001 was dit slechts bij $18 \%$ van de bedrijven het geval. Uit de tabel blijkt duidelijk dat de middelgrote bedrijven en vooral ook de kleinere bedrijven op dit punt veel actiever zijn geweest dan in het voorgaande jaar.

Tabel 1.10

Introductie van een belangrijke technologische vernieuwing in 2001 en 2002, naar bedrijfsomvang*

\begin{tabular}{lcr}
\hline Bedrijfsomvang & $\begin{array}{r}2001 \\
\%\end{array}$ & $\begin{array}{r}2002 \\
\%\end{array}$ \\
\hline $0-100$ werknemers & 12 & 34 \\
$101-250$ werknemers & 22 & 30 \\
251 of meer werknemers & 41 & 40 \\
Totaal & 18 & 34
\end{tabular}

${ }^{*}$ De verschillende percentages staan los van elkaar en hoeven dus niet op te tellen tot $100 \%$ Bron: ROA/Werkgeverspanel Metalektro 2003

Tabel 1.11 geeft aan in welke mate Metalektrobedrijven gebruik maken van geavanceerde informatietechnologie. Met name Computer Aided Design (CAD) lijkt gemeengoed te zijn. Ruim driekwart van de bedrijven werkt hiermee. Meer dan de helft van 
de bedrijven werkt ook met CNC Machines. Van Computer Aided Engineering (CAE) en Computer Aided Manufacturing (CAM) wordt daarentegen nog slechts door circa eenderde van de bedrijven gebruik gemaakt. De tabel laat ook zien dat slechts een gering deel van het personeel in hun werk daadwerkelijk met deze geavanceerde vormen van informatietechnologie te maken heeft.

Tabel 1.11

Bedrijven die gebruik maken van bepaalde informatietechnologie en gemiddeld percentage werknemers dat hiermee in het werk te maken heeft ${ }^{*}$

Techniek

Bedrijven Werknemers

$\%$

Computer Aided Design (CAD)

Computer Numeric Control (CNC Machines)

Computer Aided Engineering (CAE)

Computer Aided Manufacturing (CAM)

$\begin{array}{rr}76 & 9 \\ 56 & 15 \\ 37 & 8 \\ 32 & 9\end{array}$

${ }^{*}$ De verschillende percentages staan los van elkaar en hoeven dus niet op te tellen tot $100 \%$ Bron: ROA/Werkgeverspanel Metalektro 2003

Technische vernieuwingen van het productieproces kunnen vanzelfsprekend ook grote gevolgen hebben voor het personeel. Uit tabel 1.12 blijkt dat deze vernieuwingen, zoals verwacht mag worden, meestal leiden tot een productiviteitsstijging, waardoor er met minder mensen meer geproduceerd kan worden. In $17 \%$ van de bedrijven die vernieuwingen in hun productieproces doorvoeren, is het personeelsbestand dan ook gekrompen. Dit heeft echter slechts bij $5 \%$ van de bedrijven geleid tot gedwongen ontslagen.

Tabel 1.12

Gevolgen van technologische vernieuwing voor het personeelsbestand ${ }^{\star}$

Gevolg

Tijdelijke uitbreiding van personee

Permanente uitbreiding van personeel

Toename van het aantal lagere technische functies

Toename van het aantal hogere technische functies

Inkrimping van het personeelsbestand

Gedwongen ontslagen

Afname van het aantal lagere technische functies

Afname van het aantal hogere technische functies

Herplaatsing van personeel

Detachering van het eigen personeel

Functies worden meer specialistisch

Functies worden breder

Om- en bijscholing van personeel 22

9

8

Geen direct gevolg

53

* De verschillende percentages staan los van elkaar en hoeven dus niet op te tellen tot $100 \%$ Bron: ROA/Werkgeverspanel Metalektro 2003

Daarentegen is er veel vaker sprake van herplaatsing van personeel. Overigens is er bij één op de acht bedrijven juist sprake van een - meestal tijdelijke - uitbreiding van 
het personeel. Ook bij productieprocesvernieuwingen is er duidelijk sprake van een upgrading van het niveau van het werk. Bij bijna $15 \%$ van de bedrijven is er sprake van een afname van het aantal lagere technische functies, terwijl bij $20 \%$ van de bedrijven technologische vernieuwingen geleid hebben tot een toename van het aantal hogere technische functies. Evenals bij de bedrijven met productinnovaties, blijken de functies in de bedrijven met vernieuwingen van hun productieproces vaak meer specialistisch te worden. Dit is bij $14 \%$ van de bedrijven het geval, terwijl bij $8 \%$ van de bedrijven de functies juist breder worden. De upgrading van de vereiste kennis en vaardigheden in de bedrijven waar vernieuwingen van het productieproces plaatsvinden wordt in $22 \%$ van de bedrijven opgevangen door het bij- of omscholen van het personeel.

\section{Organisatorische veranderingen}

Productinnovaties en productieprocesvernieuwingen gaan vaak gepaard met veranderingen in de organisatie van het productieproces. Maar ook los daarvan kunnen er in bedrijven organisatorische veranderingen plaatsvinden, bijvoorbeeld als gevolg van fusies of outsourcing van productiewerkzaamheden.

Figuur 1.2

Organisatorische veranderingen in 2001 en 2002*

\section{Verandering}

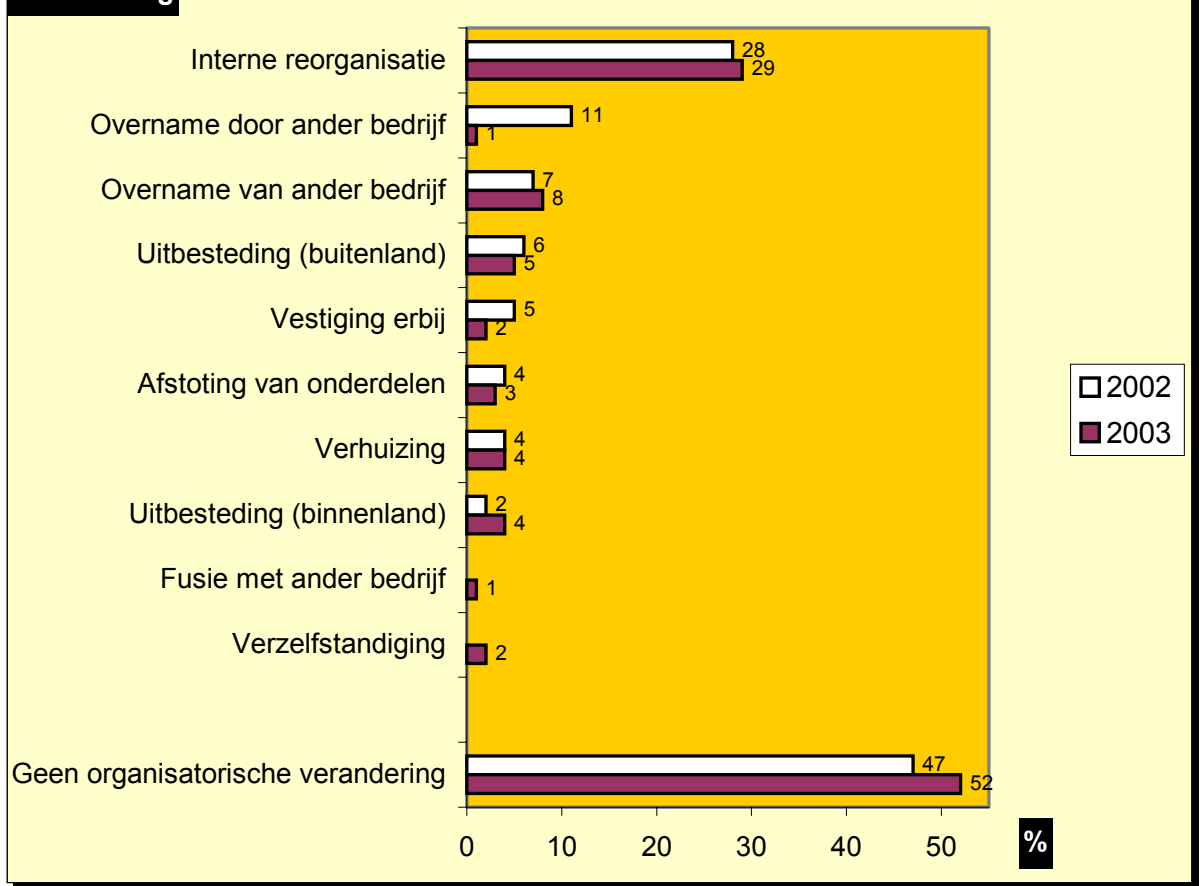

* De verschillende percentages staan los van elkaar en hoeven dus niet op te tellen tot $100 \%$. Bron: ROA/Werkgeverspanel Metalektro 2002 en 2003 
Figuur 1.2 laat zien dat er in 2002 in bijna de helft van de bedrijven organisatorische veranderingen hebben plaatsgevonden. Zo was er in drie op de tien bedrijven sprake van een interne reorganisatie. Dat is ongeveer bij evenveel bedrijven als in het voorgaande jaar. $8 \%$ van de bedrijven heeft een ander bedrijf overgenomen, terwijl $5 \%$ van de bedrijven productiewerkzaamheden heeft uitbesteed aan buitenlandse bedrijven. De verschillen met 2001 zijn in de meeste gevallen erg klein. Wel is er een duidelijke afname van het aantal bedrijven dat te maken heeft gehad met een overname door een ander bedrijf. Dit is overigens kenmerkend voor een recessieperiode.

Interne reorganisaties leiden in $42 \%$ van de bedrijven tot een herplaatsing van het personeel (zie tabel 1.13). Bij vrijwel evenveel bedrijven is er ook sprake van een inkrimping van het personeelsbestand. Vaak gaat dit gepaard met gedwongen ontslagen. Daarentegen is er bij $14 \%$ van de bedrijven die een interne reorganisatie hebben doorgevoerd een uitbreiding van het personeel. Meestal gaat het daarbij om een permanente uitbreiding. In tegenstelling tot de productinnovaties en technische vernieuwingen van het productieproces, leiden interne reorganisaties niet tot een duidelijke upgrading van de functiestructuur. Wel blijkt een reorganisatie in ruim eenvijfde van de bedrijven te leiden tot bredere functies. De herplaatsing van personeel en de functieverbreding wordt voor een belangrijk deel opgevangen door het bij- of omscholen van het personeel: In bijna eenderde van de bedrijven waar interne reorganisaties plaatsvinden leidt dit tot bij- of omscholing van het personeel.

Tabel 1.13

Gevolgen van interne reorganisaties voor het personeelsbestand ${ }^{*}$

Gevolg

Tijdelijke uitbreiding van personeel

Permanente uitbreiding van personeel

Toename van het aantal lagere technische functies

Toename van het aantal hogere technische functies

Inkrimping van het personeelsbestand

Gedwongen ontslagen

Afname van het aantal lagere technische functies

Afname van het aantal hogere technische functies

Herplaatsing van personeel

Detachering van het eigen personeel

Functies worden meer specialistisch

Functies worden breder

Om- en bijscholing van personeel

${ }^{*}$ De verschillende percentages staan los van elkaar en hoeven dus niet op te tellen tot $100 \%$. Bron: ROA/Werkgeverspanel Metalektro 2003 


\section{De structuur van de werkgelegenheid}

De sterke conjuncturele ontwikkelingen en de veranderende structuur van de productieprocessen in de Metalektro hebben gevolgen voor de werkgelegenheidstructuur. In dit hoofdstuk gaan we in op de belangrijkste kenmerken van de bedrijven en de werknemers in de Metalektro. Wat voor soort bedrijven zijn actief in de Metalektro? In hoeverre doen ze een beroep op de flexibiliteit van het personeelsbestand door bijvoorbeeld overwerk van het personeel te verlangen? Wat zijn de belangrijkste persoonskenmerken van de werknemers in de Metalektro? Daarnaast zal er worden ingegaan op de vraag in hoeverre de bij het personeel aanwezige kennis ook daadwerkelijk benut wordt en in hoeverre de bedrijven proberen de benutting van het kennispotentieel te vergroten. Het hoofdstuk sluit af met een overzicht van de belangrijkste beroepen en opleidingen in de werkgelegenheid van de Metalektrosector.

\subsection{Bedrijven in de Metalektro}

Binnen de Nederlandse industrie speelt de Metalektro een belangrijke rol. De Metalektro is binnen de industrie zowel qua werkgelegenheid als toegevoegde waarde de grootste sector. ${ }^{10}$ In totaal werken er in de 'ruime' Metalektro (inclusief de kleinmetaal) ruim 350.000 mensen. ${ }^{11}$ Dat is bijna $40 \%$ van de totale werkgelegenheid in de gehele Nederlandse industrie. Met een productiewaarde van ruim $€ 65$ miljard is de 'ruime' Metalektro goed voor bijna eenderde van de totale industriële productie.

De Metalektro is, zoals reeds in hoofdstuk 1 werd aangegeven, ook een sterk internationaal georiënteerde sector. Ruim de helft van de totale afzet van de bedrijven in de Metalektro is bestemd voor de export, terwijl het exportaandeel van de productie van andere industriële sectoren maar 39\% bedraagt. De concurrentie met bedrijven uit binnen- en buitenland vraagt doorlopend aandacht voor het behouden en versterken van de concurrentiepositie. Dit vereist dat de werkgelegenheidsstructuur zich voortdurend aanpast aan de marktomstandigheden. In dit hoofdstuk kijken we naar die werkgelegenheidsstructuur en, waar mogelijk, naar de verschuivingen die daarin in 2003 hebben plaatsgevonden.

Veel bedrijven in de Metalektro bestaan al een hele tijd. Tabel 2.1 laat zien dat bijna $40 \%$ van de Metalektrobedrijven opgericht is vóór 1950. Ongeveer een kwart van de bedrijven is opgericht na 1990. Dit benadrukt de dynamiek in de sector. Circa driekwart van de huidige bedrijven in de Metalektro bestaat al langer dan 15 jaar.

10. Zie van der Bosch, H., Centraal Bureau voor de Statistiek (2003), Branche uitgebreid: De metaal-, elektrotechnische en transportmiddelenindustrie, Industriemonitor 2003/12, Heerlen/Voorburg.

11. Volgens de CBS-definitie van de Metalektro, zie ook paragraaf 2.2. 
Tabel 2.1

Percentage bedrijven naar jaar van oprichting

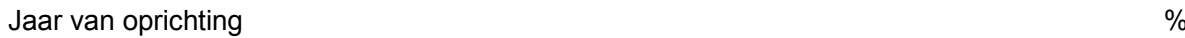

$1900-1949$

$1950-1959 \quad 10$

1960-1969 10

$1970-1979$

$1980-1989$

1990-1999 17

2000-heden 8

Bron: ROA/Werkgeverspanel Metalektro 2003

Bedrijfssector, organisatievorm, bedrijfsgrootte en regio

Tabel 2.2 geeft een overzicht van de sectoren waarin de Metalektrobedrijven actief zijn. Meer dan de helft dan de bedrijven behoort tot de sector metaalproducten of de machine-industrie. Op enige afstand volgen de elektrotechniek en de sector transportmiddelen. Het aantal bedrijven in de basismetaal is relatief klein. In vergelijking met 2002 is er in de sectorstructuur van de bedrijven weinig veranderd.

Tabel 2.2

Bedrijven naar bedrijfssector

Bedrijfssector

Basismetaal

Metaalproducten

Machine-industrie $\quad 29$

Elektrotechniek 12

Transportmiddelen $\quad 11$

Overig 14

Bron: ROA/Werkgeverspanel Metalektro 2003

Tabel 2.3 laat zien hoe de ondervraagde Metalektrobedrijven georganiseerd zijn. De meerderheid van de bedrijven (ca. 60\%) is een dochterbedrijf binnen een groter organisatorisch geheel. $35 \%$ van de bedrijven is geheel zelfstandig.

Tabel 2.3

Bedrijven naar soort organisatie

Soort organisatie $\quad \%$

Zelfstandig bedrijf

Dochterbedrijf $\quad 59$

Anders

Bron: ROA/Werkgeverspanel Metalektro 2003

In tabel 2.4 wordt er gekeken naar de personeelsomvang van de Metalektrobedrijven. De cijfers illustreren dat de kleine en middelgrote bedrijven in de 
Metalektro een belangrijke rol spelen: Zes op de tien bedrijven hebben 100 medewerkers of minder. In slechts $15 \%$ van de bedrijven is de omvang van het personeelsbestand 250 of meer.

Figuur 2.1 laat het verband zien tussen bedrijfssector en bedrijfsgrootte voor bedrijven in de Metalektro. De staven in de grafiek geven voor iedere combinatie van bedrijfssector en bedrijfsgrootte het aandeel van de bijbehorende bedrijven in de Metalektro als geheel.

Tabel 2.4

Bedrijven naar bedrijfsgrootte

Bedrijfsgrootte

Tot 50 medewerkers

100-250 medewerkers

250-500 medewerkers

500 of meer medewerkers

Bron: ROA/Werkgeverspanel Metalektro 2003

Figuur 2.1

Bedrijfssector en bedrijfsgrootte van bedrijven in de Metalektro

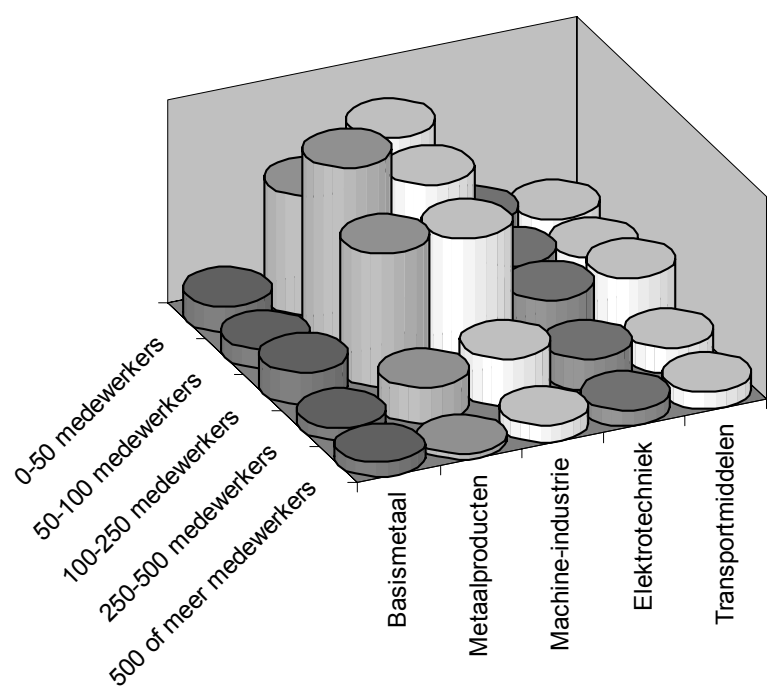

Bron: ROA/Werkgeverspanel Metalektro 2003

De figuur laat zien dat er tussen de verschillende sectoren in de Metalektro duidelijk verschillen zijn wat betreft de personeelsomvang in de bedrijven. Zo blijkt bijvoorbeeld dat er in de elektrotechniek en de machine-industrie relatief veel kleine bedrijven voorkomen. In de sector metaalproducten daarentegen komen bedrijven met 50 tot 100 medewerkers het meest voor. De basismetaal kent dan weer relatief veel bedrijven met 100-250 medewerkers. 
Tabel 2.5 geeft een beeld van de regionale spreiding van de Metalektrobedrijven. $45 \%$ van de bedrijven bevindt zich in de regio West en Zuidoost. Met een aandeel van bijna $20 \%$ staat de regio Oost op de derde positie. $14 \%$ van de Metalektrobedrijven is gevestigd In de Rijndelta. De regio's Zuidwest en Noord hebben elk een aandeel van circa $10 \%$.

Tabel 2.5

Bedrijven naar regio

Regio

Zuidwest

Zuidoost

Rijndelta

West

Oost

Noord

\section{9}

Bron: ROA/Werkgeverspanel Metalektro 2003, populatie-gegevens

Tijdelijke contracten, detachering en overwerk

Om snel in te kunnen spelen op veranderingen kunnen bedrijven op verschillende manieren hun personeelssterkte aanpassen aan de benodigde hoeveelheid werk. Zo kunnen bedrijven gebruik maken van tijdelijke contracten, personeel op detacheringsbasis inhuren en gebruik maken van overwerk. Zoals tabel 2.6 laat zien worden tijdelijke contracten in de Metalektro veel gebruikt. In bijna 7 van de 10 bedrijven is een deel van het personeel tijdelijk aangesteld. Bij de meeste bedrijven in de Metalektro heeft $10 \%$ of minder van het personeel een tijdelijk contract. In $12 \%$ van de bedrijven is het aandeel van het personeel dat tijdelijk is aangesteld groter dan $10 \%$.

Tabel 2.6

Gebruik van tijdelijke contracten naar bedrijfssector

$\begin{array}{lcc}\text { Bedrijfssector } & \begin{array}{c}\text { Tot } 10 \% \text { tijdelijk personeel } \\ \%\end{array} & \begin{array}{c}\text { Meer dan } \begin{array}{c}10 \% \text { tijdelijk personeel } \\ \%\end{array} \\ \text { Basismetaal }\end{array} \\ \text { Metaalproducten } & 86 & - \\ \text { Machine-industrie } & 70 & 4 \\ \text { Elektrotechniek } & 44 & 23 \\ \text { Transportmiddelen } & 39 & 17 \\ & 65 & 6\end{array}$

- : onvoldoende waarnemingen

Bron: ROA/Werkgeverspanel Metalektro 2003

Tussen de verschillende sectoren in de Metalektro zijn er verschillen in het gebruik van tijdelijke contracten. In de basismetaal wordt het meeste gebruik gemaakt van tijdelijk personeel. In deze bedrijven is echter nooit meer dan $10 \%$ van het personeel in tijdelijke dienst. De bedrijven in de elektrotechnische industrie maken het minst 
gebruik van tijdelijk personeel: $56 \%$ van de bedrijven in deze sector heeft tijdelijk personeel in dienst.

Het valt wel op dat de bedrijven in de elektrotechniek die gebruik maken van tijdelijk personeel, relatief vaak veel personeel op basis van tijdelijke contracten in dienst hebben. In $17 \%$ van de bedrijven in de elektrotechniek is meer dan $10 \%$ van het totale personeelsbestand tijdelijk aangesteld. In de machine-industrie heeft zelfs in bijna een kwart van de bedrijven meer dan $10 \%$ van het personeel een tijdelijk contract.

Tabel 2.7

Gebruik van detachering naar bedrijfssector

Bedrijfssector

Basismetaal

Metaalproducten

Machine-industrie

Elektrotechniek

Bron: ROA/Werkgeverspanel Metalektro 2003

Tabel 2.7 laat zien in hoeverre de Metalektrobedrijven gedetacheerd personeel inhuren. In bijna zes op de tien bedrijven in de Metalektro is gedetacheerd personeel werkzaam. De verschillen tussen de verschillende sectoren binnen de Metalektro zijn klein. Alleen in de sector elektrotechniek wordt er door bedrijven relatief weinig gebruik gemaakt van gedetacheerd personeel. Wellicht dat dit samenhangt met het al eerder geconstateerde hoge aandeel van bedrijven in de elektrotechniek dat meer dan $10 \%$ van het personeel in tijdelijke dienst heeft.

Tabel 2.8

Gebruik van overwerk naar bedrijfssector

\begin{tabular}{lccc}
\hline Bedrijfssector & $\begin{array}{c}\text { Regelmatig } \\
\%\end{array}$ & $\begin{array}{c}\text { Af en toe } \\
\%\end{array}$ & $\begin{array}{c}\text { Incidenteel } \\
\%\end{array}$ \\
\hline Basismetaal & 44 & 44 & 11 \\
Metaalproducten & 26 & 48 & 26 \\
Machine-industrie & 43 & 43 & 14 \\
Elektrotechniek & 33 & 22 & 44 \\
Transportmiddelen & 44 & 50 & 6 \\
Totaal & 36 & 44 & 20 \\
\hline
\end{tabular}

Bron: ROA/Werkgeverspanel Metalektro 2003

Ondanks de economische recessie is er in 2003 in alle Metalektrobedrijven op z'n minst incidenteel overgewerkt. Zoals tabel 2.8 laat zien komt overwerk echter in de meeste bedrijven slechts af en toe of incidenteel voor. In ongeveer eenderde van de Metalektrobedrijven komt overwerk daarentegen regelmatig voor. In de elektro- 
techniek is het aandeel van bedrijven waarin regelmatig sprake is van overwerk het laagst. In de transportmiddelensector geven relatief veel bedrijven aan dat ze af en toe gebruik maken van overwerk.

\subsection{Werknemers in de Metalektro}

In deze paragraaf zal worden ingegaan op de kenmerken van de werknemers in de Metalektro. De cijfers zijn afkomstig uit de Enquête beroepsbevolking van het CBS. Aangezien het CBS een bredere definitie van de Metalektrosector hanteert, waarbinnen bijvoorbeeld ook de kleinmetaal valt, kunnen de cijfers enigszins vertekend zijn.

\section{Persoonskenmerken}

In tabel 2.9 wordt een overzicht gegeven van een aantal belangrijke persoonskenmerken van de werkenden in de Metalektro.

Tabel 2.9

Persoonskenmerken van werkenden in de Metalektro*, naar bedrijfssector, gemiddelde 20012002

\begin{tabular}{|c|c|c|c|c|c|c|}
\hline Kenmerk & $\begin{array}{c}\text { Basis- } \\
\text { metaal } \\
\%\end{array}$ & $\begin{array}{c}\text { Metaal- } \\
\text { produkten } \\
\%\end{array}$ & $\begin{array}{l}\text { Machine- } \\
\text { industrie } \\
\%\end{array}$ & $\begin{array}{c}\text { Elektro- } \\
\text { techniek } \\
\%\end{array}$ & $\begin{array}{c}\text { Transport- } \\
\text { middelen } \\
\%\end{array}$ & $\begin{array}{c}\text { Metalektro } \\
\%\end{array}$ \\
\hline \multicolumn{7}{|l|}{ Geslacht: } \\
\hline - Vrouw & 8 & 12 & 11 & 22 & 10 & 14 \\
\hline - Man & 92 & 88 & 89 & 78 & 90 & 86 \\
\hline \multicolumn{7}{|l|}{ Leeftijd: } \\
\hline - Jong (15-29) & 12 & 22 & 21 & 19 & 21 & 20 \\
\hline - Middel (30-49) & 63 & 58 & 61 & 60 & 58 & 60 \\
\hline - Oud (50-64) & 25 & 20 & 18 & 21 & 21 & 20 \\
\hline \multicolumn{7}{|l|}{ Etniciteit: } \\
\hline - Allochtoon ${ }^{a}$ & 14 & 9 & 5 & 8 & 9 & 8 \\
\hline - Autochtoon & 86 & 91 & 95 & 92 & 91 & 92 \\
\hline
\end{tabular}

a) 'Allochtoon' heeft betrekking op niet-westerse allochtonen, iedereen waarvan ten minste één ouder in het buitenland is geboren, en waarvan de herkomst een niet-westers land is. * De cijfers in deze tabel hebben betrekking op de Metalektro inclusief de kleinmetaal. Bron: CBS/Enquête Beroepsbevolking (EBB) 2001 en 2002

In vergelijking met andere sectoren werken er in de Metalektro weinig vrouwen. Terwijl in de gehele Nederlandse economie het aandeel van werkende vrouwen rond de $40 \%$ ligt, bedraagt dit aandeel in de Metalektro slechts $14 \%$. Alleen in de elektrotechniek ligt het percentage vrouwen wat hoger (22\%).

Wat betreft de leeftijdsopbouw van de werkenden, wijkt de Metalektro weinig af van de leeftijdsopbouw van de totale werkende beroepsbevolking. Alleen in de basismetaal is het aantal jongeren relatief laag. In de jaren 2001-2002 is het aandeel jonge werknemers in de Metalektro gedaald met 4\%-punt ten opzichte van de twee voorafgaande jaren, terwijl het aandeel oudere werknemers licht gestegen is. Dit 
illustreert de voortschrijdende vergrijzing van de werkenden in de Metalektro. In de basismetaal was de stijging van het aantal oudere werknemers zelfs $6 \%$, wat inhoudt dat de vergrijzing van het personeelsbestand in deze sector zich nog duidelijker manifesteert dan in de overige sectoren in de Metalektro.

In de Metalektro is het werkgelegenheidsaandeel van het allochtone personeel hoger dan het landelijk gemiddelde van $7 \%$. In de sector basismetaal is het aandeel van allochtonen het hoogst, terwijl er in de machine-industrie juist relatief weinig allochtonen werkzaam zijn. ${ }^{12}$

\section{Opleidingsniveau}

In tabel 2.10 wordt het opleidingsniveau van de werkenden in de Metalektro (inclusief de kleinmetaal) in beeld gebracht. In de Metalektro zijn relatief veel werkenden met alleen basisonderwijs of een VMBO opleiding werkzaam. Daarentegen werken er minder mensen met een HBO of WO opleiding. In de Metalektro heeft slechts $13 \%$ van het personeel een $\mathrm{HBO}$ opleiding en $5 \%$ een WO opleiding, terwijl van de totale werkzame beroepsbevolking $19 \%$ een $\mathrm{HBO}$ opleiding heeft en $9 \%$ een universitaire opleiding. In de elektrotechniek is het aandeel van hoogopgeleiden met $32 \%$ daarentegen juist hoger dan het landelijk gemiddelde van $28 \%$. Dit illustreert het hoogtechnologische karakter van deze sector en de daarmee samenhangende complexe functies.

Tabel 2.10

Opleidingsniveau van werkenden in de Metalektro*, naar bedrijfssector, gemiddelde 2001-2002

\begin{tabular}{lcccccc} 
Opleidingsniveau & $\begin{array}{c}\text { Basis- } \\
\text { metaal } \\
\%\end{array}$ & $\begin{array}{c}\text { Metaal- } \\
\text { produkten } \\
\%\end{array}$ & $\begin{array}{c}\text { Machine- } \\
\text { industrie } \\
\%\end{array}$ & $\begin{array}{c}\text { Elektro- } \\
\text { techniek } \\
\%\end{array}$ & $\begin{array}{c}\text { Transport- } \\
\text { middelen } \\
\%\end{array}$ & Metalektro \\
\hline Basisonderwijs & 14 & 10 & 6 & 7 & 12 & 9 \\
VMBO & 23 & 33 & 24 & 21 & 28 & 26 \\
MBO & 44 & 47 & 52 & 40 & 47 & 46 \\
HBO & 13 & 8 & 14 & 21 & 10 & 13 \\
WO & 6 & 1 & 4 & 11 & 3 & 5
\end{tabular}

* De cijfers in deze tabel hebben betrekking op de Metalektro inclusief de kleinmetaal. Bron: CBS/Enquête Beroepsbevolking (EBB) 2001 en 2002

Het is opmerkelijk dat een aanzienlijk deel het personeel in de Metalektro niet beschikt over wat wordt aangeduid als een 'startkwalificatie' van de arbeidsmarkt op niveau MBO-2. Aangenomen mag worden dat deze mensen in de praktijk doorgaans toch voldoende functioneren. Dit wijst er op dat er voor deze werknemers in de Metalektro-industrie een duidelijk potentieel aanwezig is voor het opzetten van Erkenning Verworven Competenties (EVC) projecten. Gezien de voortschrijdende upgrading van de voor het werk in de Metalektro vereiste competenties is het van

12. Vanwege een verandering in definitie van het begrip 'allochtoon' is het niet mogelijk het aandeel van allochtonen te vergelijken met eerdere jaren. 
groot belang dat op deze manier de competenties van het personeel meer transparant worden gemaakt. Bovendien geeft EVC de betrokkenen vaak een impuls om de aanvullende scholing te gaan volgen die nodig is om een startkwalificatieniveau te halen.

\section{Functiekenmerken}

Tabel 2.11 laat zien dat er in de Metalektro relatief weinig in deeltijd wordt gewerkt. Terwijl 32\% van de werkzame bevolking in Nederland in deeltijd werkzaam is, werkt slechts $11 \%$ van het personeel in de Metalektro op parttime basis. Dit hangt natuurlijk sterk samen met het relatief lage percentage vrouwen dat in de Metalektro werkzaam is. Aan de andere kant geeft het ook aan dat de bedrijven in de Metalektro weinig behoefte hebben om veel deeltijders in dienst te hebben. In de elektrotechniek komt deeltijdwerk echter veel vaker voor dan in de andere sectoren van de Metalektro.

Ook zijn er in de Metalektro relatief weinig mensen werkzaam op basis van een tijdelijk arbeidscontract: $6 \%$, tegenover $8 \%$ van de gehele werkzame bevolking. Met name in de basismetaal is het percentage werkenden met een tijdelijk contract erg laag. Overigens is het aantal deeltijdwerkers in de jaren $2001 / 2002$ met $2 \%$ gestegen ten opzichte van de jaren 1999/2000. Dat zou er op kunnen duiden dat ook er binnen de Metalektrosector meer mogelijkheden komen om in deeltijd te gaan werken.

Tabel 2.11

Kenmerken van de dienstverbanden in de Metalektro*, naar bedrijfssector, gemiddelde 20012002

\begin{tabular}{lcccccc}
\hline Kenmerk & $\begin{array}{c}\text { Basis- } \\
\text { metaal } \\
\%\end{array}$ & $\begin{array}{c}\text { Metaal- } \\
\text { produkten } \\
\%\end{array}$ & $\begin{array}{c}\text { Machine- } \\
\text { industrie } \\
\%\end{array}$ & $\begin{array}{c}\text { Elektro- } \\
\text { techniek } \\
\%\end{array}$ & $\begin{array}{c}\text { Transport- } \\
\text { middelen } \\
\%\end{array}$ & Metalektro \\
\hline Deeltijd & 13 & 10 & 8 & 15 & 7 & 11 \\
Voltijd & 87 & 90 & 92 & 85 & 93 & 89 \\
Tijdelijk & 4 & 6 & 6 & 7 & 7 & 6 \\
Vast & 96 & 94 & 94 & 93 & 93 & 94
\end{tabular}

* De cijfers in deze tabel hebben betrekking op de Metalektro inclusief de kleinmetaal Bron: CBS/Enquête Beroepsbevolking (EBB) 2001 en 2002

Kennisontwikkeling en -benutting van werknemers in de Metalektro

Voordat iemand productief kan worden ingezet, is er meestal enige inwerktijd nodig. Dit is een investering in werktijd om de voor de functie noodzakelijke (bedrijfsspecifieke) kennis en vaardigheden aan te leren. Tabel 2.12 geeft voor de verschillende sectoren binnen de Metalektro een overzicht van de benodigde inwerktijd voor zowel schoolverlaters als mensen met werkervaring.

Het blijkt dat schoolverlaters die gaan werken in de Metalektro gemiddeld genomen bijna een jaar inwerktijd nodig hebben om de functie onder de knie te krijgen. Ook voor mensen die al werkervaring elders hebben is er sprake van een inwerktijd, maar deze is wel beduidend minder lang: 4 maanden. Voor mensen met werkervaring 22 
betreft de inwerktijd waarschijnlijk met name de tijd die nodig is om de specifieke kenmerken van de functie die verbonden zijn met het bedrijf aan te leren. Het verschil in werktijd is ook een duidelijke verklaring voor de voorkeur die de werkgevers in de Metalektro bij het aantrekken van personeel hebben voor mensen met enige werkervaring (zie ook tabel 3.2).

Tabel 2.12

Gemiddelde inwerktijd in maanden voor: schoolverlaters en mensen met werkervaring, naar bedrijfssector

\begin{tabular}{lcc} 
Inwerktijd & $\begin{array}{c}\text { Schoolverlaters } \\
\text { maanden }\end{array}$ & $\begin{array}{c}\text { Mensen met } \\
\text { werkervaring } \\
\text { maanden }\end{array}$ \\
\hline Basismetaal & 9 & 4 \\
Metaalproducten & 10 & 5 \\
Machine-industrie & 13 & 5 \\
Elektrotechniek & 8 & 2 \\
Transportmiddelen & 13 & 3 \\
Totaal & 11 & 4 \\
\hline
\end{tabular}

Bron: ROA/Werkgeverspanel Metalektro 2003

De inwerktijd voor schoolverlaters is het grootst in de machine-industrie en de transportmiddelensector. In de elektrotechniek is de inwerktijd daarentegen het kortst (gemiddeld 8 maanden), wat waarschijnlijk ook samenhangt met het feit dat veel schoolverlaters die in de elektrotechniek gaan werken hoogopgeleid zijn en daarom minder tijd nodig hebben om de functie aan te leren.

Voor mensen met werkervaring die gaan werken in de Metalektro is de inwerktijd het langst voor diegenen die gaan werken in de metaalproductenindustrie of in de machine-industrie. Mensen met werkervaring die gaan werken in de elektrotechniek hebben gemiddeld genomen slechts een inwerktijd van 2 maanden nodig.

Hoewel de Metalektrobedrijven vaak veel en uiteenlopende kennis in huis hebben, is het de vraag of die kennis ook volledig gebruikt wordt. In de eerste kolom van tabel 2.13 wordt daarom gekeken naar de benutting van de kennis van werknemers in de verschillende functiecategorieën. Het is opmerkelijk dat veel bedrijven aangeven dat de kennis van hun personeel niet volledig wordt gebruikt. Aan de ene kant betekent dit dat bedrijven als het ware een 'kennisreservoir' achter de hand hebben dat hen in staat stelt snel in te spelen op toenemende competentie-eisen, bijvoorbeeld als gevolg van de introductie van technologische en organisatorische innovaties. Aan de andere kant geeft het ook aan dat de Metalektro er nog onvoldoende in slaagt om het in de sector aanwezige kennispotentieel optimaal in te zetten. Zo geeft bijna zes op tien Metalektrobedrijven aan dat de kennis van werknemers in ontwikkeling en engineering functies niet volledig gebruikt wordt. Ook bij de ondersteunende functies geeft bijna de helft van de bedrijven aan dat de bij de werknemers aanwezige kennis niet volledig gebruikt wordt. Bij de technische functies en bij de functies in het hoger management ligt de benutting van de kennis van het personeel duidelijk hoger. 
Tabel 2.13

Bedrijven waarin de kennis van werknemers niet volledig gebruikt wordt en bedrijven waarbij het gebruikte gedeelte van de kennis van werknemers gestegen is, naar beroepscategorie

$\begin{array}{ccc}\text { Beroepscategorie } & \begin{array}{c}\text { Kennis van werknemers } \\ \text { niet volledig gebruikt }\end{array} & \begin{array}{c}\text { Gebruik van kennis } \\ \text { werknemers gestegen } \\ \%\end{array}\end{array}$

Uitvoerende technische functies

Leidinggevende technische functies

Ontwikkeling en engineering

Hoger management

Ondersteunende functies

$\begin{array}{rr}35 & 11 \\ 42 & 17 \\ 57 & 18 \\ 37 & 10 \\ 49 & 7\end{array}$

Bron: ROA/Werkgeverspanel Metalektro 2003

De tweede kolom van tabel 2.13 geeft een beeld van de mate waarin het gebruik van de kennis van werknemers in 2003 is gestegen. Het blijkt dat vooral de capaciteiten van werknemers in leidinggevende technische functies en degenen die betrokken zijn bij ontwikkeling en engineering meer dan in het verleden benut worden. Bedrijven lijken zich bewust te zijn van het belang om het kennispotentieel van hun medewerkers in deze functies beter te benutten. De benutting van de kennis van werknemers in ondersteunende functies is daarentegen veel minder toegenomen. Slechts $7 \%$ van de Metalektrobedrijven geeft aan dat ze nu meer dan in het verleden gebruik maken van de bij het ondersteunend personeel aanwezige kennis.

\subsection{Belangrijkste beroepen en opleidingen}

In tabel 2.14 wordt een overzicht gegeven van de belangrijkste beroepen in de Metalektro. Hoewel de meeste beroepen in de tabel technisch van aard zijn, is de werkgelegenheid in de Metalektro ook voor een aanzienlijk deel niet-technisch van aard. Dit illustreert de toenemende complexiteit van de waardeketen van de Metalektro-industrie, die zich uitstrekt van R\&D activiteiten tot engineering, assemblage, marketing \& sales (zie paragraaf 1.3). Het is wat dat betreft opvallend dat het aandeel van metaalbewerkers in de werkgelegenheid in de Metalektro ten opzichte van de vorige rapportage van de arbeidsmarktmonitor van $18 \%$ naar $14 \%$ gedaald is. De vraag naar deze groep werknemers, waartoe onder meer lassers (laag niveau), verspaners en constructiebankwerkers behoren, is blijkbaar behoorlijk gedaald. Zoals in hoofdstuk 1 werd aangegeven is de werkgelegenheid in deze uitvoerende functies in 2003 nog verder gedaald. In totaal is nog 55\% van het personeel werkzaam in technische functies, terwijl $12 \%$ werkzaam is in administratief-commerciële functies. 
Tabel 2.14

Belangrijkste beroepsgroepen binnen de Metalektro (naar percentage in de werkgelegenheid), gemiddelde 2001-2002*

Technische functies

Monteurs

Metaalbewerkers

Bankwerkers en lassers

Elektromonteurs

Productiemedewerkers

Werktuigbouwkundig ontwerpers en hoofden technische dienst

Assembleurs

Magazijnpersoneel

Medische instrumentenmakers

Installateurs

Administratieve en commerciële functies

Administratief personeel

Commercieel medewerkers (HBO niveau)

Receptionisten en administratieve employés

Commercieel medewerkers (WO niveau)

* Een beroepsgroep is alleen opgenomen als het aandeel van de beroepsgroep binnen de Metalektro minimaal $2 \%$ bedraagt.

Bron: CBS/Enquête Beroepsbevolking (EBB) 2001 en 2002

Tabel 2.15

Belangrijkste hoogst genoten opleidingstypen binnen de Metalektro (naar percentage in de werkgelegenheid), gemiddelde 2001-2002*

Opleidingstype

Basisonderwijs

VMBO mechanische techniek

VMBO theorie

VMBO bouwtechniek

MBO werktuigbouw en mechanische techniek

MBO elektrotechniek

MBO administratie en logistiek

$\mathrm{MBO}$ handel

HAVO/VWO

HBO werktuigbouwkunde

HBO elektrotechniek

HBO bedrijfskunde

* Een opleidingstype is alleen opgenomen als haar aandeel binnen de Metalektro minimaal $2 \%$ bedraagt.

Bron: CBS/Enquête Beroepsbevolking (EBB) 2001 en 2002

Tabel 2.15 geeft een beeld van de belangrijkste opleidingsachtergronden in de werkgelegenheid van de Metalektro. Ten opzichte van de vorige arbeidsmarktmonitor zijn er weinig veranderingen te constateren. De vier belangrijkste opleidingsachtergronden blijven MBO werktuigbouw en mechanische techniek, basisonderwijs, VMBO mechanische techniek en MBO elektrotechniek. 



\section{Instroom, doorstroom en uitstroom van personeel}

In 2003 is de totale werkgelegenheid in de Metalektrobedrijven afgenomen. Achter deze netto werkgelegenheidskrimp zit echter een complex patroon van instroom, uitstroom en doorstroom van personeel. In dit hoofdstuk brengen we deze stromen in beeld. Hoeveel nieuwe werknemers stroomden er in? Waar kwamen ze zoal vandaan? Hoeveel werknemers verlieten de Metalektro en waarom? Welke werknemers stroomden binnen de bedrijven door naar technische dan wel niettechnische functies? De personeelsstromen zullen zowel voor de Metalektro sector als geheel als ook voor de belangrijkste functies apart in beeld worden gebracht.

\subsection{Het totaalbeeld in de afgelopen twee jaar}

In 2002 en 2003 is de totale werkgelegenheid in de Metalektrobedrijven met ruim 14.000 werknemers gedaald. Figuur 3.1 laat zien dat er in 2002 nog sprake was van een patroon waarbij kwartalen met een sterkere teruggang in de werkgelegenheid gevolgd werden door kwartalen met minder verlies aan werkgelegenheid. In 2003 is er echter duidelijk sprake van een neergaande trend: In ieder kwartaal in 2003 is de werkgelegenheidsdaling groter dan het kwartaal daarvoor.

Het is opmerkelijk dat, ondanks de economische recessie, de instroom van nieuwe medewerkers in de Metalektro in 2002 een stijgende trend vertoonde van circa 4.000 nieuwe medewerkers in het eerste kwartaal naar bijna 5.000 in het laatste kwartaal. Daarentegen nam de instroom in 2003 in de loop van het jaar steeds verder af. Echter, ondanks de duidelijke krimp van de werkgelegenheid, worden er elk kwartaal nog steeds enkele duizenden nieuwe medewerkers in dienst genomen. De uitstroom van personeel ligt in de meeste kwartalen van 2002 en 2003 rond de 6.000 personen. Het valt op dat ondanks de recessie, de personeelsuitstroom in de loop van 2003 enigszins is afgenomen. Zowel de instroom als de uitstroom zijn in het derde kwartaal van 2003 aanzienlijk gestegen. Ondanks de algemene voorkeur voor instromers met werkervaring (zie ook tabel 3.2) nemen bedrijven bij een groot aanbod van schoolverlaters toch ook blijkbaar behoorlijk wat schoolverlaters in dienst. Een mogelijke verklaring hiervoor is dat een tijdelijk verruimde markt de bedrijven meer keuzevrijheid geeft bij het selecteren van de meest geschikte kandidaten. Als reactie op de grotere instroom is in het laatste kwartaal van 2003 de instroom van nieuw personeel behoorlijk gedaald.

In de bovenste lijn van figuur 3.1 wordt er gekeken naar wat we zouden kunnen aanduiden als de totale arbeidsmarktdynamiek in de Metalektro, oftewel de optelsom van instroom en uitstroom. De arbeidsmarktdynamiek lag in 2002 rond de 10.000 werknemers. In 2003 is er, met uitzondering van het derde kwartaal een dalende trend van de arbeidsmarktdynamiek waar te nemen. Dit laat zien dat zowel de werkgevers als werknemers in de Metalektro momenteel meer 'pas op de plaats' maken. Vooralsnog mag worden verwacht dat deze arbeidsmarktdynamiek weer zal toenemen wanneer de conjunctuur weer aantrekt. De teruglopende arbeidsmarktdynamiek in de Metalektro geeft ook aan dat de vacaturemarkt sterker is ingezakt 
dan de onderliggende werkgelegenheidsontwikkeling. Daarom kan verwacht worden, dat als de conjunctuur weer aantrekt, de vacaturemarkt zich zeer explosief kan gaan ontwikkelen.

\section{Figuur 3.1}

Het totaalbeeld van de instroom, uitstroom, werkgelegenheidsontwikkeling en arbeidsmarktdynamiek in de Metalektro, 2002 en 2003, per kwartaal

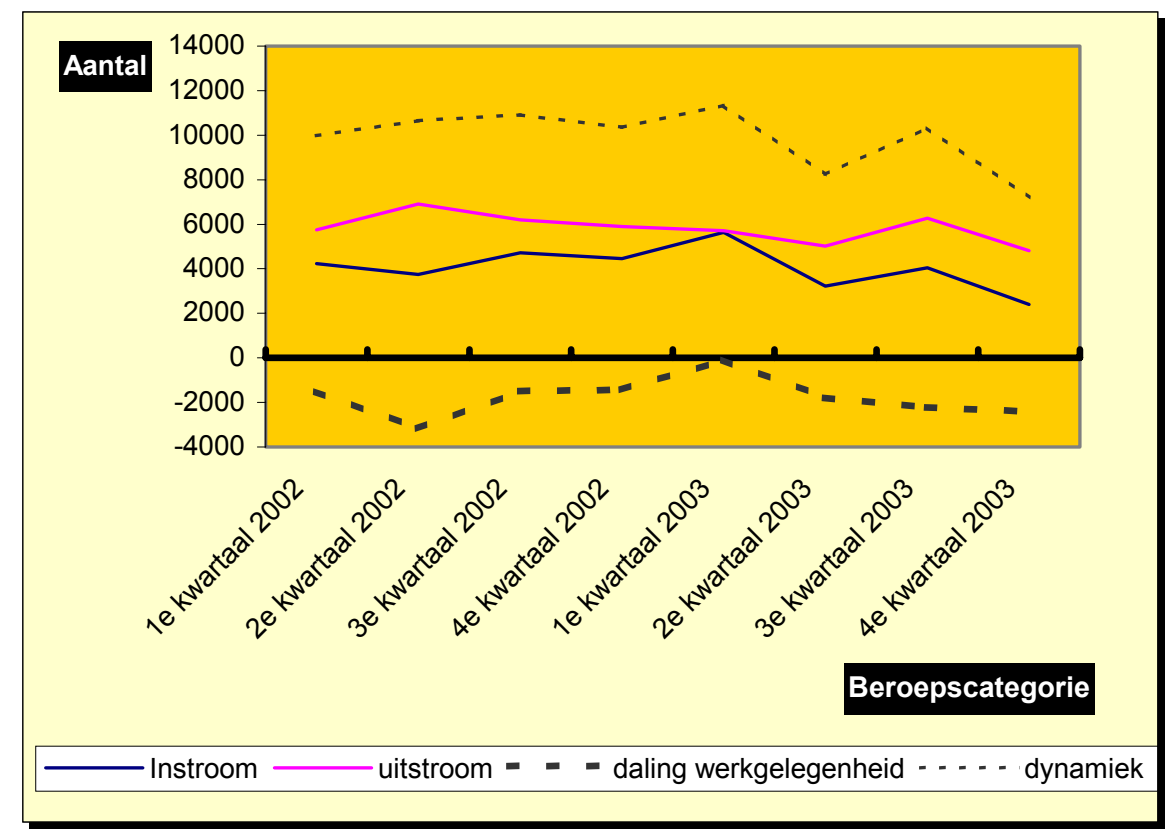

Bron: ROA/Werkgeverspanel Metalektro 2002 en 2003

\subsection{De instroom van nieuwe werknemers daalt}

Het aantal nieuwe werknemers dat in de Metalektro aan de slag ging, is in 2003 flink gedaald. Bedroeg de instroom in het eerste kwartaal nog ruim 5.500 nieuwe medewerkers, in het vierde kwartaal was dit aantal gedaald tot 2.400 . In deze paragraaf gaan we nader in op de vraag hoe deze algemene daling zich verhoudt tot de ontwikkeling van de instroom van de verschillende functiecategorieën.

Zoals figuur 3.2 laat zien is de daling van de instroom het grootst geweest voor de uitvoerende technici en de ondersteunende functies. In deze functies is de instroom in het vierde kwartaal van 2003 in vergelijking met het eerste kwartaal meer dan gehalveerd.

De uitschieter bij de instroom van uitvoerend technische beroepen in het derde kwartaal hangt samen met het feit dat in deze periode veel leerlingen het technisch beroepsonderwijs verlaten, waardoor het aanbod van schoolverlaters tijdelijk vergroot wordt. Dit laat zien dat veel Metalektrobedrijven zich bewust zijn geweest van het belang om voor hun technisch uitvoerende functies voldoende school- 
verlaters aan te trekken, om niet in problemen te komen wanneer de arbeidsmarkt weer aantrekt.

Figuur 3.2

Aantal nieuwe werknemers per kwartaal in 2003, naar beroepscategorie

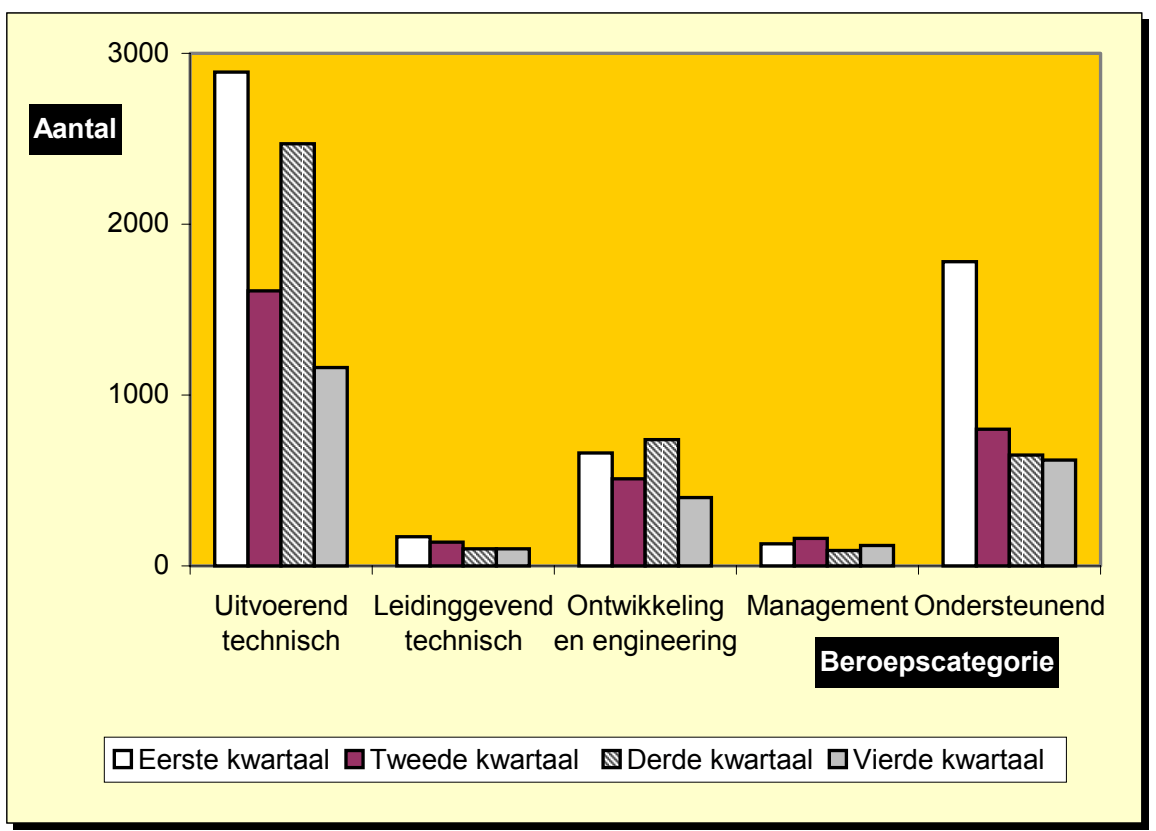

Bron: ROA/Werkgeverspanel Metalektro 2003

De instroom van personeel dat betrokken is bij ontwikkeling en engineering is gedurende 2003 gedaald van 660 in het eerste kwartaal naar 400 in het laatste. Evenals bij de uitvoerende technici, is er in het derde kwartaal sprake van een plotselinge instroomstijging. Ook hier is het waarschijnlijk dat deze uitschieter gerelateerd is aan het nieuwe aanbod van schoolverlaters dat in deze periode de arbeidsmarkt betreedt.

Voor leidinggevend technisch personeel en personeel in managementfuncties ligt de instroom op een lager niveau en zijn de ontwikkelingen van de instroomcijfers ook minder uitgesproken in vergelijking met die van het uitvoerend technisch en het ondersteunend personeel. De instroom van leidinggevend technisch en management personeel is, net zoals dat in 2002 het geval was, laag. De instroom van leidinggevend technisch personeel daalde in 2003 van 170 in het eerste kwartaal naar 100 nieuwe medewerkers in het vierde kwartaal. Deze negatieve trend staat in contrast met de ontwikkeling in 2002, waarin de instroom van leidinggevend technisch personeel nog steeg. Het lijkt er daarom op dat de minder goede economische omstandigheden ook hun weerslag krijgen in het extern werven van hoger opgeleid technisch personeel. De instroom in managementfuncties ten slotte lag in 2003 rond de 100 nieuwe medewerkers per kwartaal. 


\section{Herkomst van nieuwe werknemers}

Het is de vraag waar deze nieuwe werknemers vandaan komen. In tabel 3.1 wordt er gekeken naar de herkomst van de werknemers die in 2003 door een Metalektrobedrijf zijn aangetrokken. Het blijkt dat maar liefst 37\% van de nieuwe werknemers afkomstig is van een ander bedrijf buiten de Metalektro. Ongeveer eenzelfde deel van de nieuwe werknemers komt van een ander Metalektrobedrijf.

Tabel 3.1

Herkomst van nieuwe technische werknemers in $2003^{*}$

Herkomst

Andere vestiging bedrijf

Ander bedrijf binnen de Metalektro

Ander bedrijf buiten de Metalektro

Schoolverlater

Werkloze

Herintreder

(Gedeeltelijk) arbeidsongeschikt

Anders

* gebaseerd op de eerste drie metingen van het Werkgeverspanel Metalektro

Bron: ROA/Werkgeverspanel Metalektro 2003

Slechts $3 \%$ van nieuwe werknemers is afkomstig uit een andere vestiging van hetzelfde bedrijf. Zeven procent van de nieuwe werknemers in de Metalektro was voorheen werkloos, terwijl het aandeel van (gedeeltelijk) arbeidsongeschikten in de instroom slechts $1 \%$ bedroeg. Het aandeel van schoolverlaters in de instroom is $12 \%$. Hieruit blijkt duidelijk dat bij het aantrekken van nieuwe werknemers de nadruk ligt op werknemers met werkervaring. Zoals tabel 3.2 laat zien hangt dit sterk samen met de voorkeur van de Metalektrobedrijven: bijna tweederde van de bedrijven geeft aan dat ze bij het werven van nieuwe medewerkers de voorkeur geven aan werknemers met relevante werkervaring boven een schoolverlater met het juiste vakdiploma.

Tabel 3.2

Voorkeur bij het invullen van vacatures voor technisch personeel

Voorkeur 


\subsection{Uitstroom in de Metalektro}

In 2003 bedroeg de totale uitstroom in de Metalektro bijna 22.000 werknemers. In vergelijking met het jaar daarvoor is de totale uitstroom gedaald met circa 3.000 werknemers. In figuur 3.3 wordt per kwartaal een overzicht gegeven van het aantal werknemers dat in 2003 de Metalektrobedrijven heeft verlaten, uitgesplitst naar vijf beroepscategorieën. In het eerste kwartaal van 2003 verlieten ruim 5.700 werknemers hun bedrijf. Dit aantal daalde in het tweede kwartaal tot circa 5.000 werknemers. In het derde kwartaal was de uitstroom het hoogst: bijna 6.300 werknemers. Het vierde kwartaal van 2003 kende daarentegen weer een kleinere uitstroom van rond de 4.800 werknemers.

Figuur 3.3

Aantal vertrokken werknemers per kwartaal in 2003, naar beroepscategorie

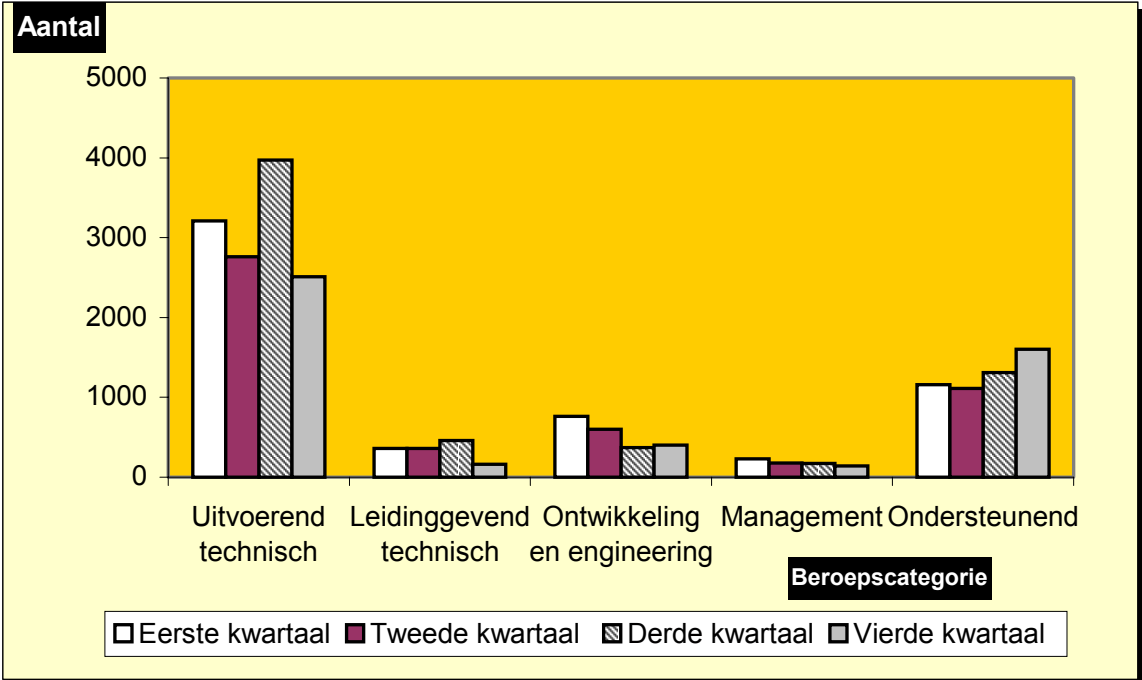

Bron: ROA/Werkgeverspanel Metalektro 2003

De uitstroom was in 2003 het hoogst voor de werknemers in uitvoerende technische functies. De uitstroom voor deze categorie werknemers lag ieder kwartaal rond de 3.000 werknemers, met uitzondering van het derde kwartaal, waarin de uitstroom circa 4.000 bedroeg. De uitstroom van het ondersteunend personeel steeg in 2003 van ruim 1.100 werknemers in het eerste kwartaal naar circa 1.600 in het vierde kwartaal. Voor de overige functies is de uitstroom beperkt.

Reden van vertrek technisch personeel

In tabel 3.3 wordt een overzicht gegeven van de belangrijkste redenen voor het vertrek van technisch personeel. Het grootste deel van het vertrekkende technisch personeel $(31 \%)$ verliet het bedrijf op onvrijwillige basis: door gedwongen ontslag. Daarnaast verliet bijna één op de vijf uitstromende werknemers het bedrijf omdat hun tijdelijk arbeidscontract afliep. Daarmee komt het aandeel van de onvrijwillige 
uitstroom op bijna de helft van de totale uitstroom. Dat is circa $10 \%$ hoger dan het aandeel van onvrijwillig vertrekkende werknemers in de uitstroom in de tweede helft van 2002.

Ongeveer een kwart van de werknemers die uitstroomden ging met (vervroegd) pensioen. De trendmatige stijging van het aandeel van pensioengangers in de uitstroom, die in 2002 gesignaleerd werd, zet zich zichtbaar door in 2003. Terwijl in 2002 in de Metalektro circa 4.100 technici met (vervroegd) pensioen gingen, bedroeg het personeelsverloop vanwege pensionering onder het technisch personeel in 2003 ruim 5.200 werknemers. Naast de vergrijzing van het personeelsbestand in veel Metalektrobedrijven, is waarschijnlijk ook de minder rooskleurige economische situatie een oorzaak van de toegenomen uitstroom vanwege pensionering. Het vervroegd met pensioen laten gaan van overtollige medewerkers is namelijk vaak een aantrekkelijk instrument om het personeelsbestand te verkleinen (zie ook tabel 4.2).

Tabel 3.3

Reden van vertrek voor technische werknemers in 2003*

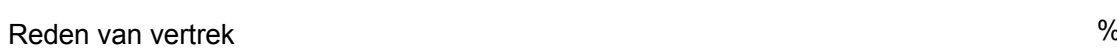

(Vervroegd) pensioen $\quad 24$

Gezondheidsredenen/arbeidsongeschiktheid 4

Overlijden 1

$\begin{array}{ll}\text { Gedwongen ontslag } & 31\end{array}$

Aflopen tijdelijk contract 18

Vrijwillig ontslag 22

* gebaseerd op de eerste drie metingen van het werkgeverspanel Metalektro

Bron: ROA/Werkgeverspanel Metalektro 2003

Het aandeel van vrijwillig ontslag in de uitstroom bedroeg in $200322 \%$. In vergelijking met het jaar daarvoor is het aandeel van werknemers dat de Metalektro vrijwillig verliet gedaald met circa $10 \%$-punt. Hieruit blijkt duidelijk dat werknemers in een recessieperiode minder vaak vrijwillig van baan veranderen.

Vier procent van de vertrekkende werknemers verlaat het bedrijf vanwege gezondheidsproblemen of arbeidsongeschiktheid. Dit aandeel is gedaald in vergelijking met het jaar daarvoor, toen nog bij ruim $6 \%$ van de uitstroom om gezondheidsredenen of arbeidsongeschiktheid ging. Het absolute aantal werkers dat om gezondheidsredenen of arbeidsongeschiktheid uitstroomden is ook gedaald: van circa 1.500 naar 900 werknemers.

\subsection{Werkgelegenheidsontwikkeling en dynamiek}

Figuur 3.4 laat zien dat de daling van de werkgelegenheid in meer of mindere mate in vrijwel alle functiecategorieën plaatsvond. Alleen voor de werknemers betrokken bij ontwikkeling en engineering in het derde kwartaal en voor het ondersteunend personeel in het eerste kwartaal was er sprake van een stijgende werkgelegenheid. 
Figuur 3.4

Daling van het aantal werknemers per kwartaal in 2003, naar beroepscategorie

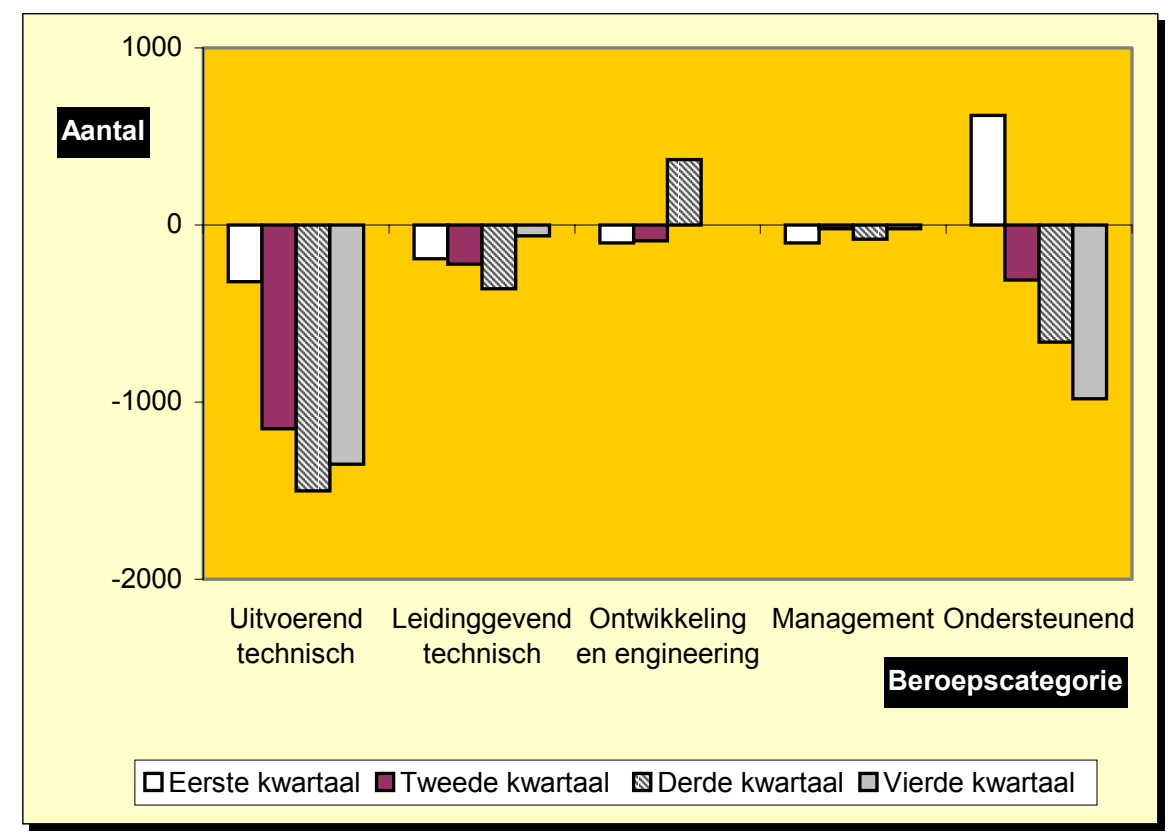

Bron: ROA/Werkgeverspanel Metalektro 2003

Voor de uitvoerende technici is de daling in de werkgelegenheid het grootst geweest. In 2003 nam het aantal uitvoerende technici in totaal met ruim 4.000 medewerkers af. In het derde kwartaal was de werkgelegenheidsdaling in deze functiecategorie het grootst. Ook voor het ondersteunend personeel in de Metalektro daalde de werkgelegenheid. Na een aanvankelijke lichte stijging van de werkgelegenheid in het eerste kwartaal, daalde de werkgelegenheid in de daaropvolgende kwartalen aanzienlijk. Voor het leidinggevend technisch personeel was de daling in het derde kwartaal het grootst. De werkgelegenheid voor managementfuncties daalde in 2003, net zoals in 2002, licht. Voor functies op het gebied van ontwikkeling en engineering steeg de werkgelegenheid op jaarbasis. Na de werkgelegenheidsdaling in het eerste en tweede kwartaal van 2003 was er in het derde kwartaal sprake van een behoorlijke stijging van de werkgelegenheid. Dit is een duidelijke illustratie van het toenemende belang van ontwikkeling en engineeringsfuncties voor de Nederlandse Metalektro-industrie. Zoals in hoofdstuk 1 werd aangegeven zal de innovativiteit van veel Metalektrobedrijven immers bepalend zijn voor hun concurrentiekracht op nationale en internationale afzetmarkten.

Naast de 'netto' ontwikkeling van de werkgelegenheid is het ook belangrijk om te kijken naar de totale personeelsdynamiek in de Metalektro. Figuur 3.5 laat zien dat in absolute termen de dynamiek het grootst is bij het uitvoerend technisch en ondersteunend personeel: In 2003 ging het om bijna 30.000 in- of uitstromende werknemers. De dynamiek is kleiner voor de overige beroepscategorieën. Voor het personeel werkzaam in managementberoepen, leidinggevende technische functies 
en de medewerkers die zich bezig houden met ontwikkeling en engineering bedroeg de totale dynamiek in 2003 circa 7.500 .

Figuur 3.5

Dynamiek (instroom plus uitstroom) op de arbeidsmarkt per kwartaal in 2003, naar beroepscategorie

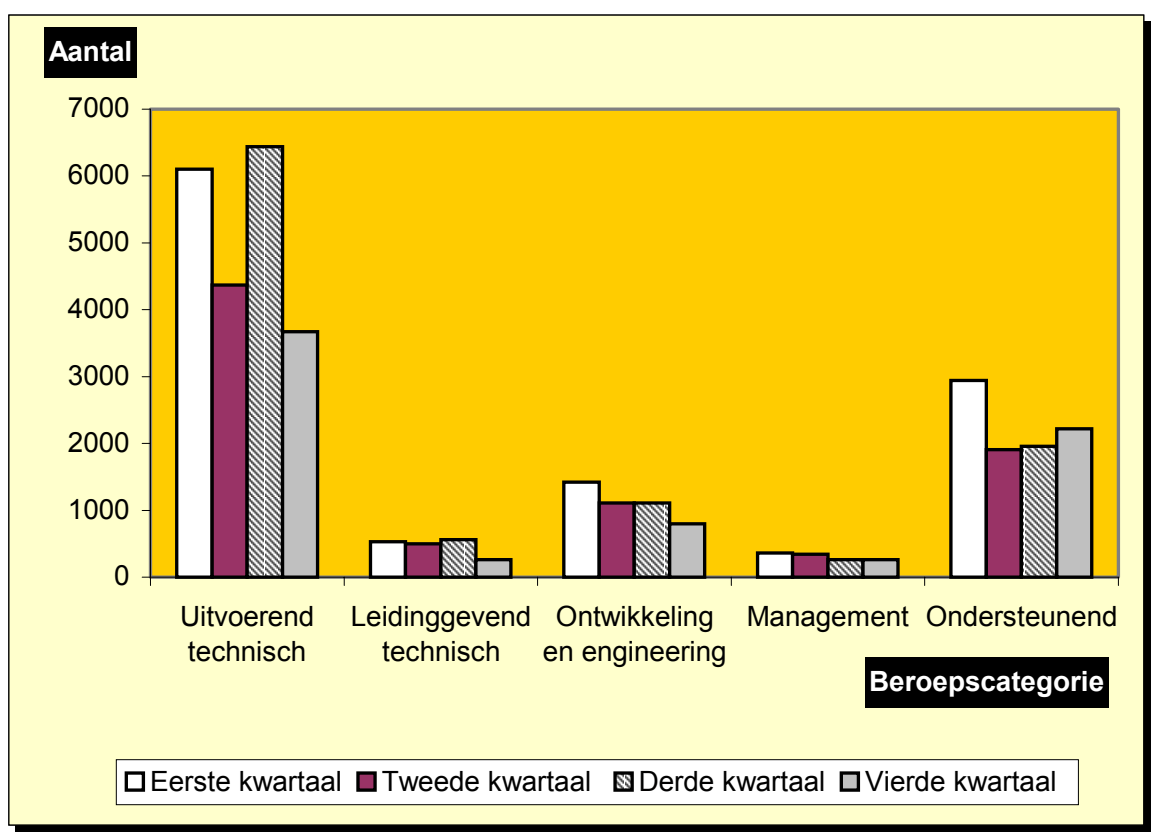

Bron: ROA/Werkgeverspanel Metalektro 2003

Hoewel de totale dynamiek meer dan $10 \%$ van het totaal aantal werkenden bedraagt is het moeilijk aan te geven of dit hoog of laag is. Daarom wordt er in figuur 3.6 gekeken naar de subjectieve beoordeling van de bedrijven op dit punt. Het gaat hier om de inschatting van het personeelsverloop in het eerste kwartaal van 2003. Om te kunnen bezien in hoeverre de inschatting verschilt met die van een jaar geleden is in de figuur tevens de inschatting voor het eerste kwartaal van 2002 opgenomen.

Het aantal bedrijven dat aangeeft dat ze te maken hebben met een hoog personeelsverloop is in 2003 ten opzichte van 2002 gedaald van 13 naar $8 \%$. Nog steeds geeft ruim $70 \%$ van de bedrijven aan dat ze weinig of erg weinig tot geen personeelsverloop ervaren. Hieruit blijkt dat bedrijven, ondanks het toenemende personeelsverloop vanwege pensionering, zich op dit punt nog geen zorgen maken. Ongetwijfeld heeft het daarbij een rol gespeeld dat het vrijwillig verloop in 2003 is ingezakt en de bedrijven vanwege de recessie weinig behoefte hadden aan het werven van arbeidskrachten. 
Figuur 3.6

Subjectieve beoordeling van het personeelsverloop onder technische werknemers in het eerste kwartaal in 2002 en 2003

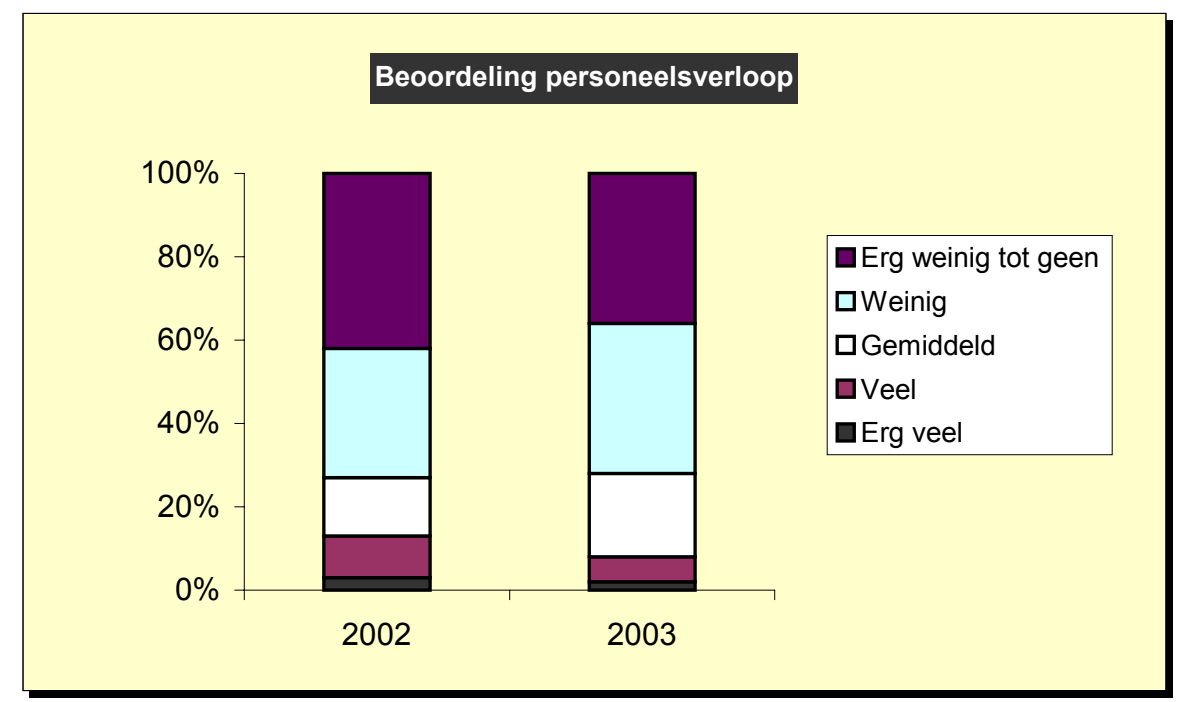

Bron: ROA/Werkgeverspanel Metalektro 2002 en 2003

\subsection{Doorstroom van personeel}

De interne doorstroom van personeel kan leiden tot zogenaamde 'vacatureketens'. De arbeidsplaatsen van het doorstromend personeel moeten immers opgevuld worden, hetzij door het extern aantrekken van nieuw personeel, hetzij door intern te werven. De personeelsdoorstroom die daardoor ontstaat vormt, naast de in- en uitstroom van het personeel, ook een bron van de dynamiek van het personeelsbestand van de bedrijven in de Metalektro. Doorstroom van personeel naar andere functies binnen het bedrijf is niet alleen een teken van een goede employability van het personeel. Het geeft ook aan dat het bedrijf goede werknemers een loopbaanperspectief biedt, hetgeen het bedrijf tot een aantrekkelijke werkgever maakt.

In tabel 3.4 wordt een overzicht gegeven van de doorstroom van het personeel in de Metalektro. Ter vergelijking zijn naast de doorstroomcijfers in 2003 ook de doorstroom in 2002 in de tabel opgenomen.

Als we naar de totale doorstroom in 2003 kijken valt het op dat er ten opzichte van 2002 veel meer personeel doorgestroomd is. De totale doorstroom is bijna verdubbeld van circa 1.700 werknemers in 2002 naar meer dan 3.000 medewerkers in 2003. Dit lijkt erop te wijzen dat ondanks de recessie het loopbaanperspectief van het personeel binnen de technische functies in veel Metalektrobedrijven niet is verminderd. Aan de andere kant zal de toename van de horizontale doorstroom ook het gevolg zijn van de herplaatsing van personeel in bedrijven die te kampen hebben met een dalende afzet. Deze toegenomen horizontale doorstroom kan overigens de employability van het personeel vergroten. 
Tabel 3.4

Doorstroom van technisch personeel, naar bestemming, 2002 en 2003

\begin{tabular}{lrr}
\hline & $\begin{array}{c}2002 \\
\text { aantal }\end{array}$ & $\begin{array}{c}2003 \\
\text { aantal }\end{array}$ \\
\hline Doorstroom van personeel & & \\
\hline Van technische naar andere technische functies & 1.460 & 2.790 \\
van een hoger niveau & 770 & 1.220 \\
van hetzelfde niveau & 630 & 1.500 \\
van een lager niveau & 60 & 70 \\
Van technische naar niet-technische functies & 260 & 380 \\
van een hoger niveau & 180 & 150 \\
van hetzelfde niveau & 70 & 210 \\
van een lager niveau & 10 & 20 \\
Totale doorstroom van technisch personeel & 1.720 & 3.170 \\
& & \\
\hline
\end{tabular}

Bron: ROA/ Werkgeverspanel Metalektro 2002 en 2003

Bijna 3.000 werknemers stroomden door van technische naar andere technische functies, terwijl bijna 400 technisch werknemers naar een niet-technische functie doorstroomden. Voor beide stromen geldt dat de meeste werknemers op hetzelfde niveau werkzaam blijven. Daarnaast is een aanzienlijk deel van de doorstroom gericht op functies van een hoger niveau. Het aantal doorstromers dat naar een lagere functie doorstroomt is, zoals te verwachten viel, klein. 


\section{$4 \quad$ Krimpende werkgelegenheid en toch vacatures?}

Hoofdstuk 1 liet zien dat bedrijven in de Metalektro in 2003 te lijden hadden onder de verslechterende economische situatie in Nederland en de rest van de wereld. De economische recessie heeft duidelijk zijn weerslag gehad op de werkgelegenheid. Zo daalde het aantal (voltijds)banen in de marktsector in de eerste drie kwartalen van 2003 met 66.000. Welke gevolgen heeft de krimpende werkgelegenheid van het technisch personeel nu in de Metalektro? Staan er nu minder vacatures open en in hoeverre hebben bedrijven zowel met een krimpende werkgelegenheid als met openstaande vacatures te maken?

\subsection{Krimpende werkgelegenheid}

Tabel 4.1 laat zien dat in de helft van de bedrijven de werkgelegenheid in 2003 is afgenomen. De daling in de werkgelegenheid blijkt met name de uitvoerende technische beroepen te treffen. Maar liefst $41 \%$ van de Metalektrobedrijven meldt een krimpende werkgelegenheid voor deze functies, al ligt dit percentage in de laatste twee kwartalen van 2003 iets lager. Voor de leidinggevende technische functies is er in circa $20 \%$ van de bedrijven een krimpende werkgelegenheid. Opvallend is dat de werkgelegenheid voor de hogere functies in de Metalektro als leidinggevende technici, ontwikkeling en engineering personeel en het hoger management in 2003 dezelfde ontwikkeling doormaakt. Het aantal bedrijven met een krimpende werkgelegenheid voor deze beroepscategorieën neemt in het tweede kwartaal wat toe, daarna in het derde kwartaal weer wat af, om vervolgens in het vierde kwartaal weer op het niveau van het eerste kwartaal uit te komen. Het aantal bedrijven met een krimpende werkgelegenheid in de ondersteunende, administratieve en commerciële functies wordt daarentegen groter in de loop van 2003.

Tabel 4.1

Bedrijven met krimpende werkgelegenheid per kwartaal in 2003, naar beroepscategorie*

\begin{tabular}{|c|c|c|c|c|}
\hline Beroepscategorie & $\begin{array}{c}\text { Eerste } \\
\text { kwartaal } \\
2003 \\
\%\end{array}$ & $\begin{array}{c}\text { Tweede } \\
\text { kwartaal } \\
2003 \\
\%\end{array}$ & $\begin{array}{c}\text { Derde } \\
\text { kwartaal } \\
2003 \\
\%\end{array}$ & $\begin{array}{c}\text { Vierde } \\
\text { kwartaal } \\
2003 \\
\%\end{array}$ \\
\hline Uitvoerende technische functies & 41 & 41 & 39 & 38 \\
\hline Leidinggevende technische functies & 21 & 26 & 16 & 21 \\
\hline Ontwikkeling en engineering & 18 & 21 & 14 & 18 \\
\hline Hoger management & 11 & 13 & 9 & 11 \\
\hline Ondersteunende functies & 28 & 25 & 31 & 35 \\
\hline Totaal & 57 & 50 & 51 & 53 \\
\hline
\end{tabular}

* De verschillende percentages staan los van elkaar en hoeven dus niet op te tellen tot $100 \%$ Bron: ROA/Werkgeverspanel Metalektro 2003

Grote bedrijven hebben vaker met een krimpende werkgelegenheid te maken dan kleine bedrijven. Dit geldt met name voor de leidinggevende technische functies, het 
hoger management en (in het vierde kwartaal) de ondersteunende, administratieve en commerciële functies. In het eerste kwartaal van 2003 daalde de werkgelegenheid van het ontwikkelings- en engineeringspersoneel vooral bij bedrijven in de Metaalindustrie, maar in de daarop volgende kwartalen zijn er geen verschillen tussen bedrijven uit de diverse sectoren binnen de Metalektro te vinden.

\section{Gevolgen van krimpende werkgelegenheid}

Tabel 4.2 geeft een overzicht van de gevolgen van de krimpende werkgelegenheid voor de bedrijven in de Metalektro. Een groot deel van de bedrijven geeft aan een vacaturestop afgekondigd te hebben. Het percentage bedrijven met een vacaturestop neemt in de loop van 2003 wel af van $77 \%$ naar $60 \%$. Ook worden in veel bedrijven met een krimpende werkgelegenheid de tijdelijke contracten niet verlengd. Dit blijkt met name in het derde kwartaal van 2003 het geval te zijn, wanneer twee op de drie bedrijven aangeeft deze maatregel te nemen. Ook worden bij een krimpende werkgelegenheid werknemers vaak naar andere functies binnen het bedrijf overgeplaatst, of gestimuleerd om een andere baan te zoeken. Opvallend is dat het percentage bedrijven met een krimpende werkgelegenheid waar werknemers gestimuleerd worden om eerder van hun pensioen of VUT gebruik te maken, gestegen is van $28 \%$ in het eerste kwartaal van 2003 tot maar liefst $42 \%$ in het vierde kwartaal. Ruim een kwart van de Metalektrobedrijven met een krimpende werkgelegenheid blijkt ook over te gaan tot gedwongen ontslagen. In het derde kwartaal van 2003 is dit zelfs bij bijna de helft van deze bedrijven het geval. Grote bedrijven blijken overigens in het algemeen op dezelfde wijze te reageren op een krimpende werkgelegenheid dan kleine bedrijven.

Tabel 4.2

Gevolgen van krimpende werkgelegenheid voor technische werknemers per kwartaal in $2003^{*}$

\begin{tabular}{|c|c|c|c|c|}
\hline Gevolg & $\begin{array}{c}\text { Eerste } \\
\text { kwartaal } \\
2003 \\
\%\end{array}$ & $\begin{array}{c}\text { Tweede } \\
\text { kwartaal } \\
2003 \\
\%\end{array}$ & $\begin{array}{c}\text { Derde } \\
\text { kwartaal } \\
2003 \\
\%\end{array}$ & $\begin{array}{c}\text { Vierde } \\
\text { kwartaal } \\
2003 \\
\%\end{array}$ \\
\hline Vacaturestop & 77 & 69 & 67 & 60 \\
\hline Tijdelijke contracten worden niet verlengd & 57 & 60 & 66 & 51 \\
\hline $\begin{array}{l}\text { Werknemers worden naar andere functies } \\
\text { binnen bedrijf overgeplaatst }\end{array}$ & 48 & 48 & 51 & 37 \\
\hline $\begin{array}{l}\text { Werknemers worden gestimuleerd om andere } \\
\text { baan te zoeken }\end{array}$ & 29 & 34 & 39 & 28 \\
\hline $\begin{array}{l}\text { Werknemers worden gestimuleerd om eerder } \\
\text { van pensioen/VUT gebruik te maken }\end{array}$ & 28 & 29 & 35 & 42 \\
\hline Gedwongen ontslagen & 22 & 29 & 46 & 26 \\
\hline Gewilde werknemers verlaten bedrijf & 5 & 5 & 4 & 9 \\
\hline Anders & 2 & 11 & 2 & 12 \\
\hline
\end{tabular}

* De verschillende percentages staan los van elkaar en hoeven dus niet op te tellen tot $100 \%$ Bron: ROA/Werkgeverspanel Metalektro 2003 


\subsection{Vacatures}

Ook al krimpt de werkgelegenheid in bijna de helft van de bedrijven in de Metalektro, toch staan er nog heel wat vacatures in de sector open. Wel is het totaal aantal vacatures in de Metalektro in de eerste drie kwartalen van 2003 afgenomen, net als in heel Nederland en in de sector industrie (zie tabel 4.3). In het vierde kwartaal van 2003 stonden er in de Metalektro weer iets meer vacatures (3.030 vacatures) open. Wellicht dat dit de eerste tekenen van een economisch herstel in de Metalektro zijn.

Tabel 4.3

Totaal aantal openstaande vacatures per kwartaal in 2003

\begin{tabular}{lcccc}
\hline & Eerste kwartaal & Tweede kwartaal & Derde kwartaal & Vierde kwartaal \\
& 2003 & 2003 & 2003 & 2003 \\
& aantal & aantal & aantal & aantal \\
& & & & - \\
Nederland & 123.500 & 125.200 & 81.400 & - \\
Industrie & 11.300 & 9.900 & 8.200 & 3.030 \\
Metalektro & 2.850 & 2.120 & 1.850 & \\
\hline
\end{tabular}

- geen gegevens beschikbaar

Bron: CBS en ROAWerkgeverspanel Metalektro 2003

\section{Figuur 4.1}

Aantal openstaande vacatures per beroepscategorie per kwartaal in 2002 en 2003

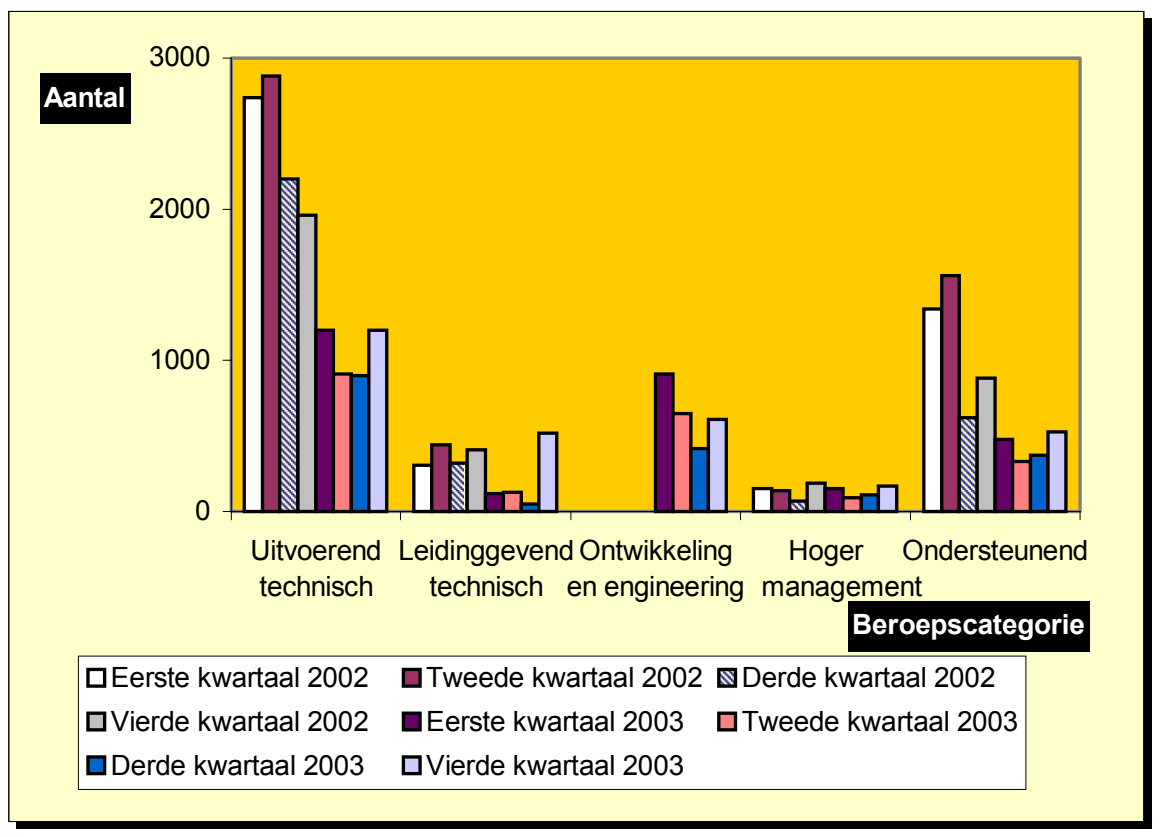

Bron: ROA/Werkgeverspanel Metalektro 2002 en 2003 
Figuur 4.1 laat duidelijk zien dat het aantal vacatures in 2003 kleiner is dan in 2002. De dalende trend in het aantal openstaande vacatures is vooral zichtbaar in de vacatures voor het uitvoerend technisch personeel, al lijkt er in het vierde kwartaal van 2003 weer sprake te zijn van een lichte opleving. Ook voor de andere beroepscategorieën staan er in het vierde kwartaal weer wat meer vacatures open. Met name voor leidinggevend technisch personeel trekt het aantal openstaande vacatures in het laatste kwartaal duidelijk aan.

Tabel 4.4 toont aan dat meer dan de helft van de Metalektrobedrijven in 2003 vacatures had openstaan. In 2002 was dit nog bij meer dan $60 \%$ van de bedrijven het geval. In het tweede en derde kwartaal van 2003 stonden er echter nog slechts bij circa $40 \%$ van de bedrijven vacatures open. Met name bij bedrijven in de machine-industrie, grote bedrijven met meer dan 250 werknemers en bedrijven in de regio Zuidoost stonden in 2003 nog vaak vacatures open.

Tabel 4.4

Bedrijven met vacatures per kwartaal in $2003^{\star}$

\begin{tabular}{lcccc}
\hline Bedrijven met vacatures & $\begin{array}{c}\text { Eerste } \\
\text { kwartaal } \\
2003\end{array}$ & $\begin{array}{c}\text { Tweede } \\
\text { kwartaal } \\
2003\end{array}$ & $\begin{array}{c}\text { Derde } \\
\text { kwartaal } \\
2003 \\
\%\end{array}$ & $\begin{array}{c}\text { Vierde } \\
\text { kwartaal } \\
2003 \\
\%\end{array}$ \\
\hline Krimpende werkgelegenheid & 29 & 23 & 32 & 29 \\
Totaal & 61 & 40 & 44 & 55
\end{tabular}

* De verschillende percentages staan los van elkaar en hoeven dus niet op te tellen tot $100 \%$ Bron: ROA/Werkgeverspanel Metalektro 2003

Opvallend is dat er bij ruim een kwart van de bedrijven in de Metalektro in 2003 ondanks de krimpende werkgelegenheid, toch vacatures openstonden. Dit wijst erop dat er in een deel van de bedrijven waar arbeidsplaatsen verdwijnen, wel degelijk behoefte is aan de instroom van nieuw personeel. Omdat in het merendeel van deze bedrijven de reguliere uitstroom groter is dan de krimp, hebben de openstaande vacatures met name betrekking op de vervangingsvraag. Alleen in het laatste kwartaal van 2003 is dit niet het geval, hetgeen betekent dat bedrijven in die periode meer behoefte hadden aan personeel met andere kennis en vaardigheden dan het personeel dat ze in dienst hebben.

Welke vacatures voor technici staan er open in $2003 ?$

Tabel 4.5 laat zien dat er in de Metalektro met name behoefte is aan uitvoerend technisch personeel op MBO-niveau. De grootste vraag is er naar werknemers in de montageberoepen; voor deze functies staan zo'n 300 vacatures open. Ook voor technici op middelbaar en hoger niveau staan in de Metalektro betrekkelijk veel vacatures open. Het aantal vacatures voor laag- en ongeschoold technisch personeel is in 2003 verder gedaald. Dit illustreert dat er in de Metalektro steeds minder vraag is naar laaggeschoolde arbeid als gevolg van de upgrading van kwalificatie-eisen, vanwege technologische of organisatorische veranderingen van 
het productieproces, of omdat bedrijven dit soort werkzaamheden steeds meer uitbesteden naar lagelonenlanden.

Tabel 4.5

Aantal technische vacatures in 2003 , naar functie

\begin{tabular}{|c|c|c|}
\hline Functie & $\begin{array}{c}\text { Eerste } \\
\text { kwartaal } \\
2003 \\
\text { aantal }\end{array}$ & $\begin{array}{c}\text { Derde } \\
\text { kwartaal } \\
2003 \\
\text { aantal }\end{array}$ \\
\hline \multicolumn{3}{|l|}{ Laag-en ongeschoold personeel } \\
\hline Laag- en ongeschoold personeel & 240 & 250 \\
\hline \multicolumn{3}{|l|}{ Uitvoerende technici op MBO niveau } \\
\hline Machinaal verspanende beroepen & 180 & 80 \\
\hline Bankwerk beroepen & 110 & 100 \\
\hline Plaatverwerkende beroepen & 80 & 0 \\
\hline Pijpverwerkende beroepen & 110 & 130 \\
\hline Montage beroepen & 310 & 300 \\
\hline Elektromonteurs & 180 & 30 \\
\hline Lasberoepen & 70 & 80 \\
\hline Procesoperators & - & 120 \\
\hline Overige geschoolde technische vaklieden & 140 & 110 \\
\hline \multicolumn{3}{|c|}{ Overig technisch personeel op middelbaar en hoger niveau } \\
\hline Tekenaars/constructeurs & 120 & 100 \\
\hline Werkvoorbereiders & 120 & 60 \\
\hline Automatiseringspersoneel / IT'ers & 40 & 70 \\
\hline Overig & 280 & 410 \\
\hline
\end{tabular}

- Geen informatie beschikbaar

Bron: ROA/Werkgeverspanel Metalektro 2003

Er zijn geen verschillen in het soort vacatures dat openstaat tussen bedrijven met een krimpende werkgelegenheid en bedrijven met een stabiele of stijgende werkgelegenheid. Wel blijken, vergeleken met bedrijven in de machine-industrie en de metaalproductensector, bedrijven uit de overige sectoren binnen de Metalektro minder vaak vacatures voor tekenaars of constructeurs en voor werkvoorbereiders te hebben openstaan. Bedrijven die metaalproducten maken hebben daarentegen wat vaker openstaande vacatures in de montageberoepen.

Duur van de openstaande vacatures

Tabel 4.6 laat zien dat iets meer dan de helft van de vacatures voor technisch personeel in de Metalektro korter dan 3 maanden openstaat. De rest van de vacatures is volgens de gangbare definitie als moeilijk vervulbaar te kwalificeren. $15 \%$ van de vacatures staat zelfs langer dan een jaar open. In 2002 lag dit percentage op ongeveer $10 \%$. Over het algemeen kan gesteld worden dat vacatures in 2003 langer openstonden dan in 2002. Bedrijven in de Metalektro kunnen hun vacatures voor technisch personeel dus niet sneller vervullen nu de arbeidsmarkt minder krap geworden is. In tegendeel, ze hebben vaker met moeilijk vervulbare vacatures te kampen dan in 2002. Dit laat zien dat bijna de helft van de vacatures 
betrekking heeft op functies waarvoor het aanbod van geschikt personeel tekort schiet.

Tabel 4.6

Duur van openstaande vacatures voor technisch personeel in 2003

\begin{tabular}{lcc}
\hline Duur & $\begin{array}{c}\text { Eerste kwartaal } \\
2003 \\
\%\end{array}$ & $\begin{array}{c}\text { Derde kwartaal } \\
2003 \\
\%\end{array}$ \\
\hline Korter dan 3 maanden & \multicolumn{2}{c}{} \\
3 tot 6 maanden & 54 & 57 \\
6 tot 12 maanden & 29 & 16 \\
Langer dan 12 maanden & 10 & 12 \\
& 6 & 15 \\
\hline
\end{tabular}

Bron: ROA/Werkgeverspanel Metalektro 2003

Vergeleken met bedrijven die een krimpende werkgelegenheid hebben, staan vacatures bij bedrijven met een stabiele of stijgende werkgelegenheid niet korter of langer open. Wel kunnen grote bedrijven hun vacatures vaak sneller invullen dan kleine bedrijven. Dit zou erop kunnen wijzen dat grote bedrijven aantrekkelijkere werkgevers voor technisch personeel zijn dan kleine bedrijven. Ook bedrijven in de machine-industrie lijken hun vacatures wat sneller te kunnen in dan bedrijven in de andere sectoren binnen de Metalektro.

\section{Ontstaan van vacatures}

Vacatures kunnen om twee redenen ontstaan: vanwege een groei van de werkgelegenheid (de uitbreidingsvraag) of vanwege de vervanging van personeel dat vertrokken is door pensionering, arbeidsongeschiktheid, terugtrekking van de arbeidsmarkt en het vinden van werk in andere bedrijven of sectoren (de vervangingsvraag). In een stagnerende economie mag men verwachten dat vacatures vooral betrekking hebben op de vervangingsvraag.

Figuur 4.2 laat zien dat dit inderdaad het geval is, al is er bij bijna de helft van de bedrijven toch ook sprake geweest van vacatures vanwege een toename van de hoeveelheid werk. Wel is het percentage bedrijven dat vacatures heeft als gevolg van de uitbreidingsvraag sterk teruggevallen ten opzichte van 2002. In het eerste kwartaal van 2003 had $48 \%$ van de bedrijven vacatures voor technisch personeel door de groei van hun bedrijf of een toename van de hoeveelheid werk. In het eerste kwartaal van 2002 was dit nog 65\%. Zes van de tien bedrijven heeft daarentegen vacatures openstaan omdat personeel is vertrokken. $9 \%$ van de bedrijven heeft ook vacatures vanwege (langdurige) ziekte van werknemers, terwijl $14 \%$ van de bedrijven andere redenen voor het ontstaan van vacatures voor technisch personeel aangeven. Deze hebben voornamelijk betrekking op het vervangen van personeel dat overgeplaatst is naar andere functies binnen het bedrijf. 
Figuur 4.2

Reden van ontstaan van vacatures voor technische werknemers in 2002 en 2003 volgens bedrijven met vacatures

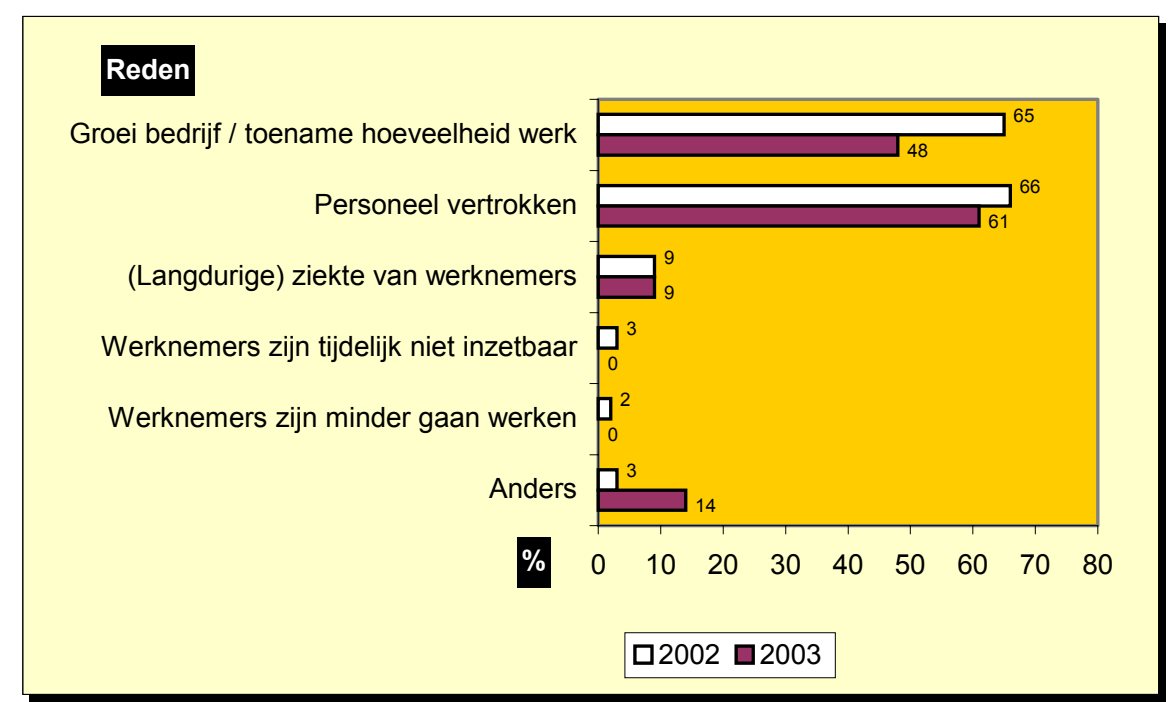

Bron: ROA/Werkgeverspanel Metalektro 2002 en 2003

\subsection{Problemen bij het vervullen van vacatures}

Door de recessie en de daarmee gepaard gaande ruimere arbeidsmarkt mag verwacht worden dat bedrijven in de Metalektro minder problemen ondervinden bij het vinden van geschikt technisch personeel. Tabel 4.7 laat zien dat dit inderdaad het geval is. Zo heeft $33 \%$ van de bedrijven in het eerste kwartaal van 2003 helemaal geen problemen op dit gebied, terwijl vier op de tien bedrijven aangeeft (erg) weinig problemen te ondervinden. In het eerste kwartaal van 2002 lagen deze percentages nog beduidend lager. Het is echter opmerkelijk dat nog steeds één op de tien bedrijven aangeeft (erg) veel problemen te hebben met het vinden van technisch personeel.

Tabel 4.7

Beoordeling van problemen bij het vinden van technisch personeel in 2002 en 2003

\begin{tabular}{lrr}
\hline Beoordeling & 2002 & 2003 \\
& $\%$ & $\%$ \\
\hline Erg veel problemen & & \\
Veel problemen & 5 & 7 \\
Gemiddelde problemen & 14 & 18 \\
Weinig problemen & 22 & 34 \\
Erg weinig problemen & 24 & 6 \\
Geen problemen & 9 & 33
\end{tabular}

Bron: ROA/Werkgeverspanel Metalektro 2002 en 2003 
Tussen de verschillende sectoren binnen de Metalektro zijn er weinig verschillen in de mate waarin men problemen ondervindt bij het vinden van geschikt technisch personeel. Ook zijn er op dit punt geen verschillen tussen kleine en grote bedrijven. Wel is het opvallend dat zowel de bedrijven met weinig vacatures (een vacaturegraad kleiner dan 2) en de bedrijven met veel vacatures (een vacaturegraad groter dan 5) minder problemen ondervinden bij het vinden van technisch personeel, dan bedrijven met een vacaturegraad tussen de 2 en de 5 . Dit zou verklaard kunnen worden doordat de problemen bij weinig vacatures meevallen, terwijl bedrijven bij veel vacatures meer aandacht gaan besteden aan hun wervingsbeleid, waardoor men minder problemen ondervindt bij het vinden van geschikt personeel. Ten slotte zijn er enkele regionale verschillen. Bedrijven uit de regio Rijndelta hebben minder problemen met het vinden van technisch personeel, terwijl bedrijven in de regio's Zuidwest en Noord juist meer problemen ondervinden.

Figuur 4.3

Belangrijkste problemen bij het vervullen van openstaande vacatures voor technisch personeel in 2002 en 2003 volgens bedrijven met problemen

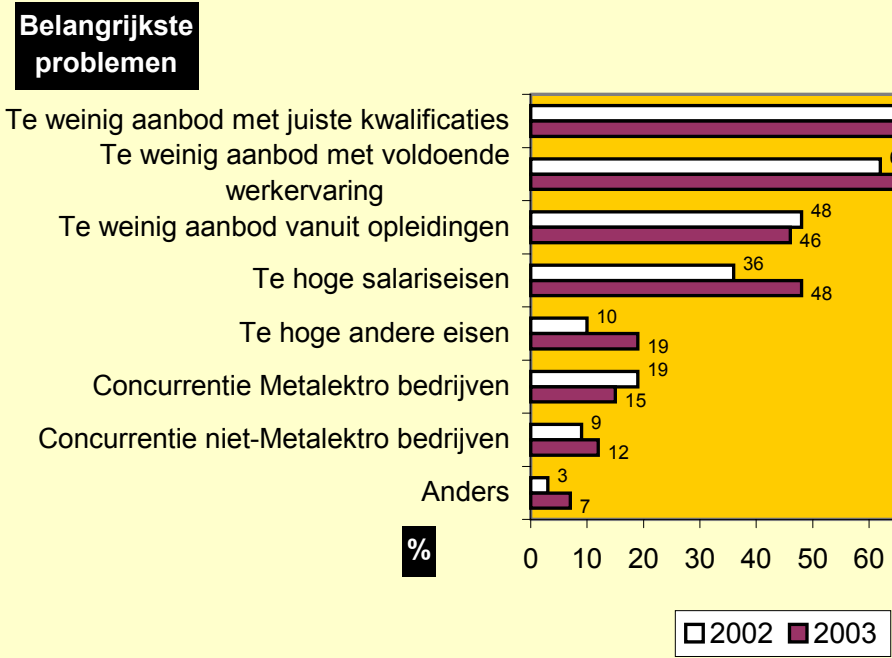

Bron: ROA/Werkgeverspanel Metalektro 2002 en 2003

Wat zijn nu de belangrijkste problemen die bedrijven in de Metalektro tegenkomen bij het invullen van vacatures voor technisch personeel? Net als in 2002, wordt meestal als reden aangegeven 'te weinig aanbod van technici met de juiste kwalificaties' en 'te weinig aanbod van technici met voldoende werkervaring' (zie figuur 4.3). Ook de lage instroom vanuit de technische opleidingen wordt door veel bedrijven als een belangrijk probleem gemeld. Opvallend is dat het stellen van te hoge salariseisen en te hoge andere eisen vaker als een probleem gezien wordt dan in 2002. Blijkbaar stellen sollicitanten in de huidige economische situatie salariseisen, waaraan de bedrijven niet (meer) tegemoet willen komen. Ten slotte ondervindt een gedeelte van de bedrijven in de Metalektro bij het vervullen van openstaande vacatures voor het technisch personeel concurrentie van andere bedrijven binnen en buiten de 
Metalektro. Met name bedrijven in Oost Nederland geven aan bij het aantrekken van personeel de concurrentie van niet-Metalektro bedrijven een probleem te vinden.

Tabel 4.8 geeft meer inzicht in de concurrentie die de Metalektrobedrijven ondervinden bij de werving van nieuw technisch personeel. Duidelijk is dat de meeste bedrijven bij de huidige ruime arbeidsmarkt weinig concurrentie ondervinden. De meeste concurrentie is regionaal en wordt veroorzaakt door zowel bedrijven binnen de Metalektro als bedrijven uit andere sectoren (met name de kleinmetaal). Concurrentie van bedrijven buiten de regio speelt nauwelijks een rol. Hieruit blijkt duidelijk dat de meeste Metalektrobedrijven hun personeel op de regionale arbeidsmarkt werven. Er zijn op dit punt vrijwel geen verschillen tussen kleine en grote bedrijven en tussen de verschillende sectoren binnen de Metalektro. Wel blijkt dat met name bedrijven uit de regio Rijndelta meer concurrentie van Metalektrobedrijven in de regio ondervinden.

Tabel 4.8

Concurrentie bij de werving van technisch personeel in 2003

\begin{tabular}{lccc}
\hline Concurrentie & (Zeer) veel & $\begin{array}{c}\text { Niet veel, } \\
\text { niet weinig } \\
\%\end{array}$ & (Zeer) weinig \\
& $\%$ & 35 & 47 \\
Metalektro bedrijven in de regio & 18 & 19 & 71 \\
Metalektro bedrijven buiten de regio & 9 & 25 & 58 \\
Niet-Metalektro bedrijven in de regio & 16 & 19 & 77 \\
Niet-Metalektro bedrijven buiten de regio & 5 & &
\end{tabular}

Bron: ROA/Werkgeverspanel Metalektro 2003

\section{Gevolgen van het tekort aan technisch personeel}

Bij de bedrijven die in 2003 nog problemen hadden met het vinden van technisch personeel, waren de gevolgen van deze problemen ook minder groot dan in 2002 (zie tabel 4.9). Toch zijn de gevolgen nog wel aanzienlijk. Zo noemt $63 \%$ van de bedrijven met personeelstekorten dat door de tekorten de werkdruk is toegenomen. Bijna $40 \%$ van de bedrijven geeft aan dat werk is blijven liggen of dat deadlines gemist zijn, terwijl $28 \%$ van de bedrijven met een tekort aan technisch personeel hogere wervings- en opleidingskosten maakt en bij $13 \%$ orders verloren gaan. Opvallend is dat bedrijven in 2003 wat vaker melden dat het tekort aan technisch personeel ten koste gaat van de concurrentiepositie van het bedrijf. Dit geldt met name voor bedrijven die met een krimpende werkgelegenheid te maken hebben. $15 \%$ van de bedrijven noemt nog andere gevolgen van het tekort aan technisch personeel, zoals de achteruitgang van de kwaliteit van de productie en het uitstellen van minder dringende klussen als onderhoud van machines. 
Tabel 4.9

Gevolgen van het tekort aan technisch personeel volgens bedrijven met problemen bij het vinden van technisch personeel*

\begin{tabular}{lrr}
\hline Gevolg & $\begin{array}{r}2002 \\
\%\end{array}$ & $\begin{array}{r}2003 \\
\%\end{array}$ \\
\hline Toegenomen werkdruk & 75 & 63 \\
Werk blijft liggen / deadlines gemist & 45 & 39 \\
Hogere wervings- of opleidingskosten & 37 & 28 \\
Verlies aan orders & 18 & 13 \\
Slechtere concurrentiepositie & 11 & 14 \\
Anders & 3 & 15
\end{tabular}

${ }^{*}$ De verschillende percentages staan los van elkaar en hoeven dus niet op te tellen tot $100 \%$ Bron: ROA/Werkgeverspanel Metalektro 2002 en 2003

\subsection{Werving, selectie en interne aanpassingen}

Hoe gaan bedrijven in de Metalektro in een ruimere arbeidsmarkt met hun (moeilijk vervulbare) vacatures om? Over het algemeen blijkt dat iets meer dan de helft van de bedrijven met vacatures maatregelen neemt. Ter vergelijking: in 2002 was dit nog bij zeven op de tien bedrijven het geval. Het maakt in dit opzicht niet uit of bedrijven veel of weinig vacatures hebben. Wel blijken bedrijven met een krimpende werkgelegenheid opvallend vaker maatregelen te treffen om hun vacatures ingevuld te krijgen dan bedrijven met een stabiele of stijgende werkgelegenheid. Blijkbaar is er deze bedrijven veel aan gelegen om de vacatures die er zijn snel en adequaat op te vullen.

Tabel 4.10 laat zien hoe bedrijven hun wervings- en selectiebeleid hebben aangepast. Duidelijk is dat bedrijven in deze ruime arbeidsmarkt minder vaak concessies hoeven te doen. Zo kiezen bedrijven minder vaak dan in 2002 voor het aannemen van mensen met minder ervaring, een lager opleidingsniveau of een andere opleidingsrichting. Dit betekent dat ze meer dan in 2002 goed gekwalificeerd personeel kunnen aannemen. Ook gaan bedrijven minder vaak over tot het bieden van hogere salarissen of het aanbieden van betere, CAO overstijgende arbeidsvoorwaarden. Opvallend is verder dat bedrijven veel minder vaak actief scholieren benaderen; het percentage bedrijven dat deze maatregel neemt is gezakt van $32 \%$ in 2002 naar $15 \%$ in 2003 . Wel blijken bedrijven bij vacatures iets vaker het CWI (het voormalige arbeidsbureau) in te schakelen. Uitzendbureaus of commerciële wervings- en selectiebureaus zijn echter ook nog steeds erg populair in de Metalektro: $41 \%$ van de bedrijven met vacatures schakelt deze bureaus in. 
Tabel 4.10

Aanpassingen in het wervings- en selectiebeleid bij bedrijven met (moeilijk vervulbare) vacatures voor het technisch personeel in 2002 en 2003*

Aanpassing in wervings- en selectiebeleid

Inschakelen uitzendbureaus of commerciële werving- en selectiebureaus

$\begin{array}{rr}56 & 41 \\ 39 & 26 \\ 32 & 15 \\ 20 & 15 \\ 17 & 11 \\ 13 & 14 \\ 11 & 3 \\ 8 & 4 \\ 2 & 7 \\ 30 & 47\end{array}$

Geen aanpassingen in wervings- en selectiebeleid

* De verschillende percentages staan los van elkaar en hoeven dus niet op te tellen tot $100 \%$ Bron: ROA/Werkgeverspanel Metalektro 2002 en 2003

Overigens is het percentage bedrijven dat bij (moeilijk vervulbare) vacatures helemaal geen aanpassingen in hun wervings- en selectiebeleid treft, in 2003 veel groter dan in 2002 (47\% tegenover 30\%). Blijkbaar verwachten veel bedrijven dat hun vacatures in deze ruime arbeidsmarkt zonder veel problemen ingevuld kunnen worden.

\section{Schoolverlaters of werknemers met ervaring?}

Is de voorkeur van bedrijven in de Metalektro voor het aantrekken van een bepaald soort werknemer veranderd nu de arbeidsmarkt ruimer geworden is? Zoals tabel 3.2 al liet zien blijkt dat bedrijven bij een vacature voor technisch personeel nog steeds de voorkeur geven aan een werkende of werkzoekende met relevante werkervaring $(65 \%)$ boven een schoolverlater met een relevant vakdiploma (12\%). Bijna een kwart van de bedrijven heeft geen duidelijke voorkeur.

Overigens blijken bedrijven in de metaalproductensector wat vaker de voorkeur te geven aan schoolverlaters. Ook kleine bedrijven hebben vaker een voorkeur voor schoolverlaters dan middelgrote en grote bedrijven. Zoals we eerder in dit hoofdstuk zagen, hebben de kleine bedrijven ook vaker te kampen met moeilijk vervulbare vacatures. Dit zou een reden kunnen zijn waarom zij hun voorkeuren hebben bijgesteld. Er is geen sprake van duidelijke regionale verschillen in de wervingsvoorkeuren van bedrijven.

\section{Wervingskanalen}

Tabel 4.11 laat zien dat er grote verschillen zijn in de effectiviteit van wervingskanalen tussen het uitvoerend en leidinggevend technisch personeel. Uitvoerend technisch personeel kan volgens de bedrijven het beste geworven worden door uitzendbureaus (33\%), een advertentie in een regionaal dagblad $(28 \%)$ of via het 
eigen personeel (20\%). Om leidinggevend technisch personeel te werven, kunnen bedrijven het best een advertentie in een regionaal (35\%) of landelijk (10\%) dagblad plaatsen of een commercieel wervingsbureau inschakelen (17\%). Andere wervingskanalen worden door beduidend minder bedrijven als het meest effectief beschouwd.

Uit het werkgeverspanel Metalektro blijkt dat het meest effectieve kanaal voor de werving voor technisch personeel niet voor ieder bedrijf hetzelfde is. De bedrijfssector, bedrijfsgrootte, regionale ligging en economische situatie zijn allemaal factoren die invloed hebben op de effectiviteit van wervingskanalen.

Vergeleken met bedrijven uit de machine-industrie en de metaalproductensector, geven bedrijven in de andere sectoren binnen de Metalektro vaker aan dat ze het inschakelen van uitzendbureaus een effectieve manier vinden om uitvoerend technisch personeel te werven. Voor het werven van leidinggevend technisch personeel vinden ze vaker externe relaties geschikt. Bedrijven in de machineindustrie menen daarentegen vaker dat het eigen personeel het meest effectieve kanaal is om leidinggevend personeel te werven.

Tabel 4.11

Meest effectieve wervingskanaal voor uitvoerend en leidinggevend technisch personeel in 2003

\begin{tabular}{|c|c|c|}
\hline Wervingskanaal & $\begin{array}{l}\text { Uitvoerend technisch } \\
\text { personeel } \\
\%\end{array}$ & $\begin{array}{c}\text { Leidinggevend technisch } \\
\text { personeel } \\
\%\end{array}$ \\
\hline Uitzendbureau & 33 & 6 \\
\hline Advertentie in regionaal dagblad & 28 & 35 \\
\hline Eigen personeel in bedrijfsvestiging & 20 & 9 \\
\hline Externe relaties & 4 & 9 \\
\hline Commercieel wervingsbureau & 3 & 17 \\
\hline CWI (arbeidsbureau) & 2 & 1 \\
\hline School/opleiding & 2 & 1 \\
\hline Open sollicitatie & 2 & 2 \\
\hline Internet & 2 & 5 \\
\hline Personeel in andere bedrijfsvestigingen & 1 & 2 \\
\hline Advertentie in landelijk dagblad & 1 & 10 \\
\hline Advertentie in vakblad & 1 & 4 \\
\hline Anders & 3 & 1 \\
\hline
\end{tabular}

Bron: ROA/Werkgeverspanel Metalektro 2003

Grote bedrijven vinden vaker open sollicitaties een effectief wervingskanaal voor uitvoerend technisch personeel dan kleine bedrijven. Waarschijnlijk omdat zij ook meer open sollicitaties ontvangen dan kleine bedrijven. Middelgrote bedrijven met tussen de 100 en 250 werknemers geven bij de werving van leidinggevend technisch personeel vaker de voorkeur aan het plaatsen van een advertentie in een vakblad. Middelgrote en grote bedrijven ten slotte vinden het Internet vaker geschikt voor het werven van deze categorie werknemers dan kleine bedrijven.

Er zijn ook regionale verschillen in de effectiviteit van de wervingskanalen. Bedrijven in de regio Rijndelta vinden bij het werven van uitvoerend technisch personeel het 
plaatsen van een advertentie in een vakblad vaker effectief dan bedrijven in andere regio's. Het inschakelen van uitzendbureaus wordt door hen daarentegen als minder positief beoordeeld, terwijl bedrijven in Noord Nederland dit wel vaker als het meest effectieve wervingskanaal noemen. Het werven van leidinggevend technisch personeel via het eigen personeel wordt in Noord Nederland vaker als effectief beschouwd. Bedrijven in de regio's Rijndelta en Oost Nederland geven vaker aan dat leidinggevend technisch personeel het beste geworven kan worden door het plaatsen van een advertentie in een landelijk dagblad.

Interne aanpassingen

Bedrijven kunnen om hun (moeilijk vervulbare) vacatures ingevuld te krijgen ook maatregelen nemen die de organisatie van het werk in het bedrijf zelf treffen. Tabel 4.12 geeft een overzicht van deze interne aanpassingen. Veel bedrijven (43\%) kiezen voor overwerk. Waarschijnlijk is dit ook de goedkoopste en snelste oplossing om met vacatures voor technisch personeel om te gaan. Het flexibel inzetten van de huidige werknemers is ten opzichte van 2002 wat afgenomen, maar blijt een populaire aanpassing (33\%). Ook het uitbesteden van werk naar andere bedrijven in Nederland en het om- en bijscholen van werknemers vindt in meer dan $30 \%$ van de bedrijven met moeilijk vervulbare vacatures plaats.

Tabel 4.12

Interne aanpassingen bij bedrijven met (moeilijk vervulbare) vacatures voor het technisch personeel in 2002 en $2003^{*}$

Interne aanpassing

$2002 \quad 2003$

$\% \quad \%$

Overwerk

$53 \quad 43$

Flexibel inzetten van huidige werknemers

Uitbesteden van werk (binnenland)

Om- of bijscholen van huidige werknemers

Uitbesteden van werk (buitenland)

Automatiseren

Productie beperken

Geen interne aanpassingen

$48 \quad 33$

$40 \quad 32$

$40 \quad 31$

179

$14-8$

$10 \quad 12$

* De verschillende percentages staan los van elkaar en hoeven dus niet op te tellen tot $100 \%$ Bron: ROA/Werkgeverspanel Metalektro 2002 en 2003

In vergelijking met 2002, gaan bedrijven er in 2003 wat minder vaak toe over om bij vacatureproblemen werk uit te besteden naar het buitenland $(9 \%)$ of om te automatiseren (8\%). Daarentegen wordt wel vaker de productie beperkt (12\%). 



\section{De noodzaak van scholing}

In dit hoofdstuk wordt ingegaan op de noodzaak van scholing voor de bedrijven in de Metalektro. In hoeverre worden economische, technologische en organisatorische veranderingen in het bedrijf opgevangen door om- en bijscholing van het personeel? En wordt scholing ingezet om met demografische ontwikkelingen (de toenemende vergrijzing) om te gaan? Ook zal aandacht besteed worden aan het bevorderen van scholing door belemmerende factoren bij cursusparticipatie weg te nemen, het gebruik van subsidies en financieringsbronnen te stimuleren en het gericht inzetten van HRM-instrumenten die de cursusparticipatie vergroten.

\subsection{Waarom scholing?}

Zoals in hoofdstuk 1 reeds werd aangegeven is het voor de concurrentiepositie van de Nederlandse Metalektro-industrie van groot belang zich te richten op het vermarkten van hoogwaardige en dus kennisintensieve producten en diensten. Op deze hoogwaardige marktsegmenten concurreren bedrijven vooral op basis van de kwaliteit van hun producten en dienstverlening. De concurrentiepositie van een bedrijf wordt dan ook in belangrijke mate bepaald door de mate waarin men kan beschikken over goed opgeleid personeel dat weet om te gaan met de meest moderne technologie. Het personeel zal naast vaktechnische kennis en vaardigheden ook over voldoende communicatieve vaardigheden dienen te beschikken en oog moeten hebben voor de wensen van de klanten. Bovendien moet men in staat zijn om producten en productieprocessen voortdurend te vernieuwen. Innovatieve bedrijven kunnen dit alleen realiseren als ze de beschikking hebben over personeel dat voldoende "employable" is om met deze ontwikkelingen mee te kunnen gaan en dat bereid is om zich bij te scholen wanneer dat nodig is.

Tabel 5.1

Noodzaak van om- of bijscholen van het technisch personeel voor een optimaal productieproces in 2002 en 2003

\begin{tabular}{lrr}
\hline Om- of bijscholing & 2002 & 2003 \\
& $\%$ & $\%$ \\
\hline Helemaal niet nodig & & 0 \\
Nauwelijks nodig & 0 & 6 \\
Enigszins nodig & 7 & 64 \\
Zeer nodig & 49 & 30 \\
\hline
\end{tabular}

Bron: ROA/Werkgeverspanel Metalektro 2002 en 2003

Het overgrote deel van de bedrijven in de Metalektro blijkt zich ook duidelijk bewust te zijn van de noodzaak hun personeel voldoende te scholen. Tabel 5.1 laat zien dat $30 \%$ van de bedrijven het voor een optimaal productieproces zeer nodig vindt om hun technisch personeel om- of bij te scholen, terwijl nog eens $64 \%$ van de bedrijven dit enigszins nodig vindt. Slechts $6 \%$ van de bedrijven is van mening dat om- of bijscholing nauwelijks nodig is. Deze cijfers gelden zowel voor grote als kleine 
bedrijven. Ook zijn er op dit punt geen verschillen tussen bedrijven uit de verschillende sectoren binnen de Metalektro. Wel schatten bedrijven in Noord Nederland de noodzaak voor scholing wat lager in, terwijl bedrijven in Oost Nederland het belang van scholing juist hoger inschatten.

Tabel 5.1 laat echter ook zien dat bedrijven in 2002 beduidend vaker aangaven dat ze de om- of bijscholing van hun technisch personeel zeer nodig vinden. Men zou hieruit kunnen concluderen dat de urgentie van de noodzaak tot scholing in economisch minder gunstige tijden toch wat afneemt. Het percentage bedrijven dat om- of bijscholing nauwelijks of helemaal niet nodig vindt is echter niet veranderd.

Veruit de meeste bedrijven zijn het ook (zeer) eens met de stelling dat bedrijven in de Metalektro ook in de huidige economische situatie voldoende dienen te investeren in de scholing van het technisch personeel. Figuur 5.1 laat zien dat het hier om 93\% van de bedrijven gaat; de rest $(7 \%)$ staat neutraal tegenover deze stelling.

\section{Figuur 5.1}

Beoordeling van stelling "Bedrijven in de Metalektro dienen ook in de huidige economische situatie voldoende te investeren in de scholing van het technisch personeel".

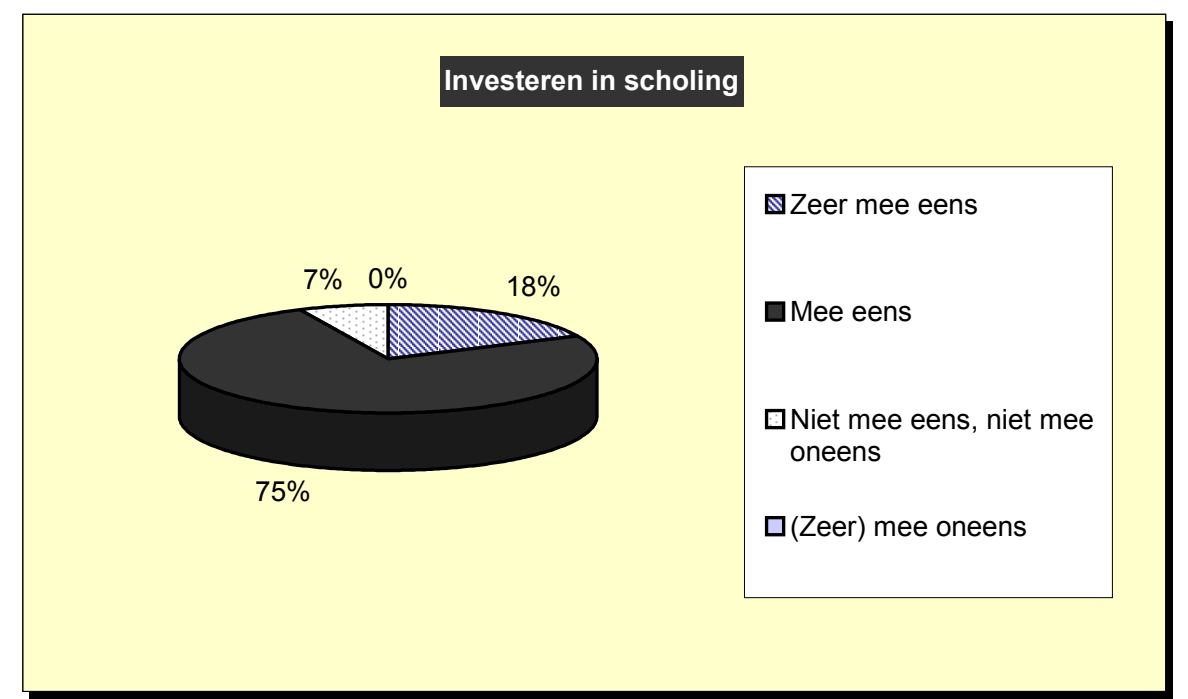

Bron: ROA/Werkgeverspanel Metalektro 2003

De noodzaak van scholing is wellicht het meest evident wanneer er sprake is van tekorten in de kennis en vaardigheden bij het personeel. Deze competentietekorten zullen immers weggewerkt moeten worden om het productieproces optimaal te laten verlopen. Competentietekorten kunnen op verschillende wijzen ontstaan. Zoals in hoofdstuk 1 werd beschreven, worden bedrijven geconfronteerd met economische, technologische en organisatorische ontwikkelingen die ervoor zorgen dat de vraag naar bepaalde kennis en vaardigheden in de loop der tijd verschuift. Zo kunnen de toenemende concurrentie tussen bedrijven, de introductie van nieuwe producten of productietechnieken en veranderingen in de organisatie van het werk er toe leiden dat de competenties van het personeel niet langer up-to-date zijn en men nieuwe 
competenties moet aanleren. Deze noodzaak tot om- en bijscholing wordt nog versterkt door de demografische ontwikkelingen. Door de toenemende vergrijzing van de beroepsbevolking, wordt het moeilijker om jonger personeel aan te trekken. Bedrijven zullen daardoor meer aangewezen zijn op de inzet van oudere arbeidskrachten die wel dienen te beschikken over kennis en vaardigheden die nog steeds up-to-date zijn.

\section{Competenties van het technisch personeel}

Over het algemeen is het overigens goed gesteld met de competenties van het technisch personeel in de Metalektro. Tabel 5.2 laat zien dat de meeste bedrijven geen of slechts geringe tekorten in de kennis en vaardigheden van hun personeel kennen. Zo geeft $46 \%$ van de bedrijven aan dat er geen sprake is van een tekort aan vaktechnische vaardigheden; $44 \%$ van de bedrijven spreekt van een klein tekort. Eén op de tien bedrijven vindt echter dat hun technisch personeel met een groot tekort aan vaktechnische vaardigheden kampt. Dit is een verontrustende constatering.

De grootste problemen lijken zich overigens voor te doen bij de meer algemene competenties 'communicatie', 'probleemoplossend vermogen', en 'leidinggeven'. Maar liefst $15 \%$ tot $22 \%$ van de bedrijven geeft aan dat hun technisch personeel een groot tekort heeft aan deze competenties. In 2002 bleken dit ook al de probleemgebieden van het technisch personeel te zijn. Rond de $40 \%$ van de bedrijven gaf toen aan dat het niveau van deze competenties onvoldoende of matig was. Blijkbaar zijn de bedrijven er in 2003 niet in geslaagd om deze competentietekorten weg te werken. Dit geldt echter niet voor de commerciële vaardigheden. In 2002 vond nog 46\% van de bedrijven dat hun technisch personeel over onvoldoende of matige commerciële vaardigheden beschikte, in 2003 meldt slechts $5 \%$ van de bedrijven nog een groot tekort in deze vaardigheden.

Tabel 5.2

Competentietekorten bij het technisch personeel in 2003

\begin{tabular}{lccc}
\hline Competentie & $\begin{array}{c}\text { Groot tekort } \\
\%\end{array}$ & $\begin{array}{c}\text { Klein tekort } \\
\%\end{array}$ & $\begin{array}{c}\text { Geen tekort } \\
\%\end{array}$ \\
\hline Vaktechnische vaardigheden & 10 & 44 & 46 \\
Werken met computer / IT & 2 & 51 & 47 \\
Probleemoplossend vermogen & 21 & 50 & 29 \\
Werken in teamverband & 7 & 40 & 53 \\
Zelfstandig werken & 7 & 48 & 45 \\
Leidinggeven & 15 & 46 & 39 \\
Communicatie & 22 & 50 & 28 \\
Commerciële vaardigheden & 5 & 37 & 59 \\
\hline
\end{tabular}

Bron: ROA/Werkgeverspanel Metalektro 2003

Opvallend is dat grote bedrijven (meer dan 250 werknemers) vaker aangeven dat er sprake is van een tekort in het probleemoplossend vermogen van hun technisch personeel dan kleine bedrijven. Dit lijkt erop te wijzen dat er bij grote bedrijven een sterkere verschuiving is in de mate waarin het technisch personeel zelfstandig 
beslissingen moet kunnen nemen dan dat dit bij kleinere bedrijven het geval is. Er zijn overigens geen verschillen in competentietekorten tussen de verschillende sectoren binnen de Metalektro. Wel geven de bedrijven uit de regio's West en Rijndelta vaker aan dat hun personeel een tekort heeft aan communicatieve vaardigheden dan bedrijven uit andere regio's.

Wanneer we verder inzoomen op de kerncompetenties van het technisch personeel - de vaktechnische vaardigheden - dan blijkt dat er duidelijk sprake is van een upgrading van deze vaardigheden. Tabel 5.3 geeft aan dat in maar liefst $42 \%$ van de bedrijven het niveau van de vaktechnische vaardigheden van het technisch personeel is toegenomen. In 2002 was dit percentage nog hoger (54\%), hetgeen aangeeft dat de upgrading van vaktechnische competenties in 2002 sterker was dan in 2003. De helft van de bedrijven vindt dat het niveau van deze competenties in 2003 gelijk gebleven is aan dat van 2002, terwijl $8 \%$ van de bedrijven zelfs van mening is dat het niveau gedaald is. Bij grote bedrijven is het niveau in vaktechnische vaardigheden overigens wat minder vaak toegenomen en wat vaker gelijk gebleven dan bij kleine bedrijven.

Tabel 5.3

Veranderingen in het niveau van vaktechnische vaardigheden van het technisch personeel in 2002 en 2003

\begin{tabular}{lrr}
\hline Vaktechnische vaardigheden & 2002 & 2003 \\
& $\%$ \\
\hline Niveau is afgenomen & & 8 \\
Niveau is gelijk gebleven & 39 & 50 \\
Niveau is toegenomen & 54 & 42
\end{tabular}

Bron: ROA/Werkgeverspanel Metalektro 2002 en 2003

Veranderende vraag naar competenties

Figuur 5.2 laat zien dat, naast het goed kunnen werken met de computer, met name het beschikken over voldoende probleemoplossend vermogen en communicatieve vaardigheden in 2003 belangrijker is geworden voor het goed functioneren van het technisch personeel. Ongeveer $60 \%$ van de bedrijven geeft dit aan, terwijl er vrijwel geen bedrijven zijn die het belang van deze vaardigheden ziet afnemen. Dit betekent dat de relatief grote competentietekorten die op deze terreinen in de Metalektro bestaan, nog verergerd worden door het toenemend belang dat de bedrijven hechten aan probleemoplossend vermogen en communicatie. Omdat het belang van vaktechnische vaardigheden, werken in teamverband en zelfstandig werken eveneens in veel bedrijven is toegenomen, wordt er bovendien steeds meer van het technisch personeel in de Metalektro gevraagd. 
Figuur 5.2

Verandering in het belang van competenties voor het goed functioneren van het technisch personeel

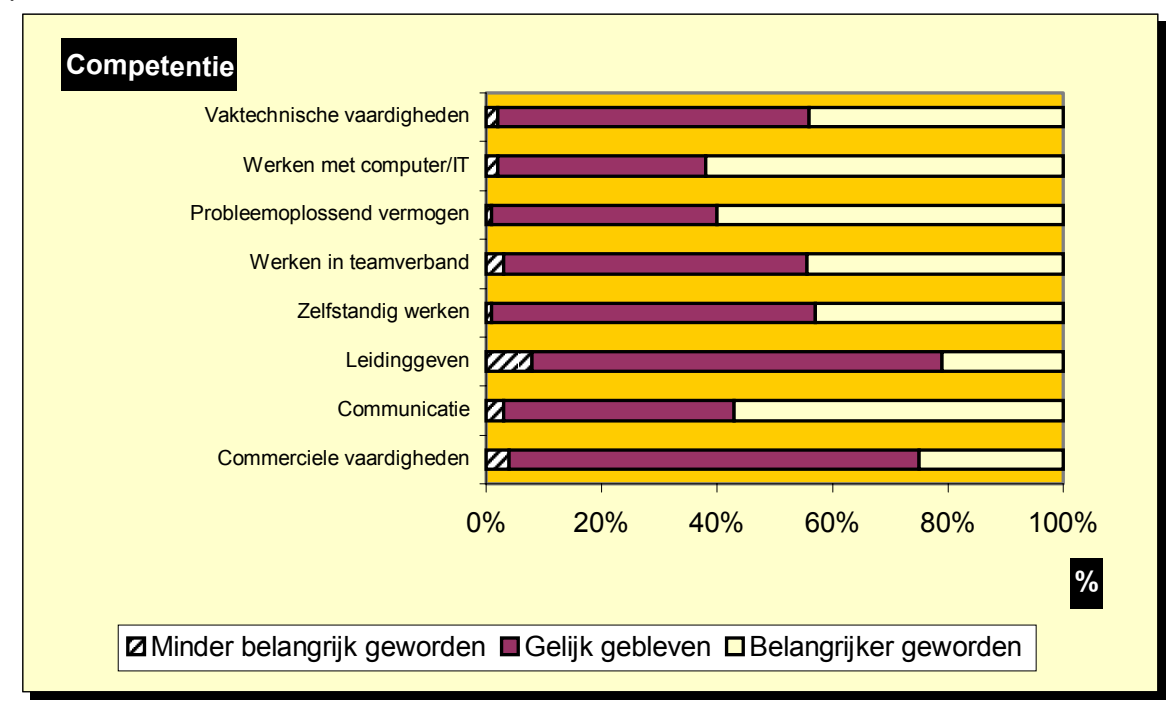

Bron: ROA/Werkgeverspanel Metalektro 2003

Net als in 2002, is het belang van leidinggeven en commerciële vaardigheden in 2003 niet gegroeid. Een klein aantal bedrijven geeft zelfs aan dat deze competenties minder belangrijk geworden zijn voor het goed functioneren van het technisch personeel. Dit zou erop kunnen wijzen dat managementtaken en verkoop en acquisitie steeds meer door gespecialiseerde, niet-technische werknemers verricht worden. Kleine bedrijven geven vaker aan dat vaktechnische vaardigheden belangrijker worden voor het goed functioneren van het technisch personeel dan grotere bedrijven. Ook zijn er enkele regionale verschillen: bedrijven in de regio's Oost en Noord Nederland vinden vaker dat probleemoplossend vermogen en leidinggeven belangrijker worden dan de Metalektrobedrijven in de andere regio's. Daarentegen zijn er geen duidelijke verschillen tussen de sectoren binnen de Metalektro.

\section{Inspelen op de ontwikkelingen in het bedrijf}

In hoofdstuk 1 is een overzicht gegeven van de economische, technologische en organisatorische ontwikkelingen waar bedrijven in de Metalektro mee geconfronteerd worden. Deze ontwikkelingen zorgen ervoor dat bedrijven andere eisen stellen aan de competenties van hun personeel. Om op deze ontwikkelingen in te kunnen spelen, staan bedrijven twee opties ter beschikking, die men zou kunnen typeren als een 'make or buy' beslissing. In de eerste plaats kunnen bedrijven hun personeel scholing laten volgen waarin men zich de vereiste kennis en vaardigheden eigen kan maken. Bedrijven kunnen hierbij hun personeel opleiden op de werkplek of hen cursussen aanbieden. Dit wordt ook wel de trainingsoptie genoemd. Het bedrijf kiest dan ten aanzien van de personeelsontwikkeling voor een 'make' strategie. Daarnaast 
kunnen bedrijven nieuw gekwalificeerd personeel aannemen. Dit is de wervingsoptie, oftewel een 'buy' strategie.

Tabel 5.4 geeft een overzicht van de verschillende manieren waarop bedrijven op economische, technologische en organisatorische veranderingen inspelen. Het is duidelijk dat de meeste bedrijven bij economische, technologische en organisatorische ontwikkelingen voor de trainingsoptie kiezen. Meer dan $80 \%$ van de bedrijven leidt het personeel op de werkplek op. Dit zelf opleiden vindt met name plaats wanneer er een nieuwe productietechniek in het bedrijf geïntroduceerd wordt; $90 \%$ van de bedrijven leidt dan het personeel op de werkplek op. Daarnaast biedt meer dan $70 \%$ van de bedrijven het personeel cursussen aan wanneer er zich bepaalde vernieuwingen in het bedrijf voordoen. Dit is met name het geval wanneer er een nieuwe productietechniek geïntroduceerd wordt $(87 \%)$ en wanneer technische functies in het bedrijf steeds meer allround worden (85\%). De wervingsoptie wordt door beduidend minder bedrijven gekozen. Het aannemen van nieuw, gekwalificeerd personeel vindt met name plaats wanneer technische functies in het bedrijf steeds specialistischer worden (56\%). Kennelijk is er dan behoefte aan specialisten die men niet in voldoende mate in huis heeft en ook niet door aanvullende training intern kan ontwikkelen.

Tabel 5.4

Inspelen op economische, technologische en organisatorische ontwikkelingen door bedrijven in 2003*

\begin{tabular}{|c|c|c|c|c|c|}
\hline Ontwikkeling & $\begin{array}{c}\text { Opleiden } \\
\text { op } \\
\text { werkplek } \\
\%\end{array}$ & $\begin{array}{c}\text { Aanbieden } \\
\text { cursus } \\
\%\end{array}$ & $\begin{array}{c}\text { Werven } \\
\text { personeel } \\
\%\end{array}$ & Anders & Geen \\
\hline \multicolumn{6}{|l|}{ Economische ontwikkelingen } \\
\hline Concurrentie is toegenomen & 84 & 72 & 30 & 6 & 9 \\
\hline Klanten worden veeleisender & 85 & 76 & 39 & 2 & 7 \\
\hline \multicolumn{6}{|l|}{ Technologische ontwikkelingen } \\
\hline Nieuwe productietechniek & 90 & 87 & 41 & 1 & 2 \\
\hline Toenemende automatisering & 82 & 76 & 41 & 2 & 9 \\
\hline \multicolumn{6}{|l|}{ Organisatorische ontwikkelingen } \\
\hline Technische functies specialistischer & 83 & 69 & 56 & 1 & 8 \\
\hline $\begin{array}{l}\text { Technische functies meer all-round } \\
\text { Meer verantwoordelijkheden op lager }\end{array}$ & 81 & 85 & 39 & 3 & 9 \\
\hline $\begin{array}{l}\text { niveau } \\
\text { Minder verantwoordelijkheden op lager }\end{array}$ & 84 & 79 & 38 & 4 & 10 \\
\hline niveau & - & - & - & - & - \\
\hline
\end{tabular}

- onvoldoende waarnemingen

* De verschillende percentages staan los van elkaar en hoeven dus niet op te tellen tot $100 \%$.

Bron: ROA/Werkgeverspanel Metalektro 2003

Een klein aantal bedrijven speelt op de verschillende ontwikkelingen in door het nemen van andere maatregelen, zoals het uitbesteden van werkzaamheden. Vooral bedrijven die te maken hebben met een toenemende concurrentie kiezen hier soms voor. Ten slotte neemt minder dan één op de tien bedrijven helemaal geen maat- 
regelen om met economische, technologische en organisatorische veranderingen in het bedrijf om te gaan. Over het algemeen kiezen kleine bedrijven er vaker voor geen speciale maatregelen te treffen dan middelgrote of grote bedrijven. Waarschijnlijk heeft een dergelijk 'laissez-faire' beleid op de korte termijn geen al te grote effecten voor de concurrentiepositie van deze bedrijven. Men kan zich echter afvragen of deze bedrijven zich op de wat langere termijn op hun afzetmarkten kunnen handhaven. Op een gegeven moment zal men immers achter de feiten gaan aanlopen.

Inspelen op demografische ontwikkelingen: de vergrijzing

In hoofdstuk 7 zal worden ingegaan op de vergrijzingsproblematiek in de Metalektro. Hieruit zal blijken dat $42 \%$ van de bedrijven problemen heeft bij de vervanging van gepensioneerd technisch personeel. Ook bij deze demografische ontwikkelingen kan de om- en bijscholing van personeel een oplossing bieden. Bedrijven kunnen hun eigen technische werknemers zo opleiden, dat zij de taken van personeel dat met (pré)pensioen gaat, kunnen overnemen (trainingsoptie). Ook kunnen bedrijven door om- en bijscholing, taakroulatie en een goed loopbaanbeleid er toe bijdragen dat oudere arbeidskrachten op een wat latere leeftijd de arbeidsmarkt verlaten.

\section{Figuur 5.3}

Maatregelen om met problemen bij de vervanging van gepensioneerd technisch personeel om te gaan voor bedrijven met problemen in 2003

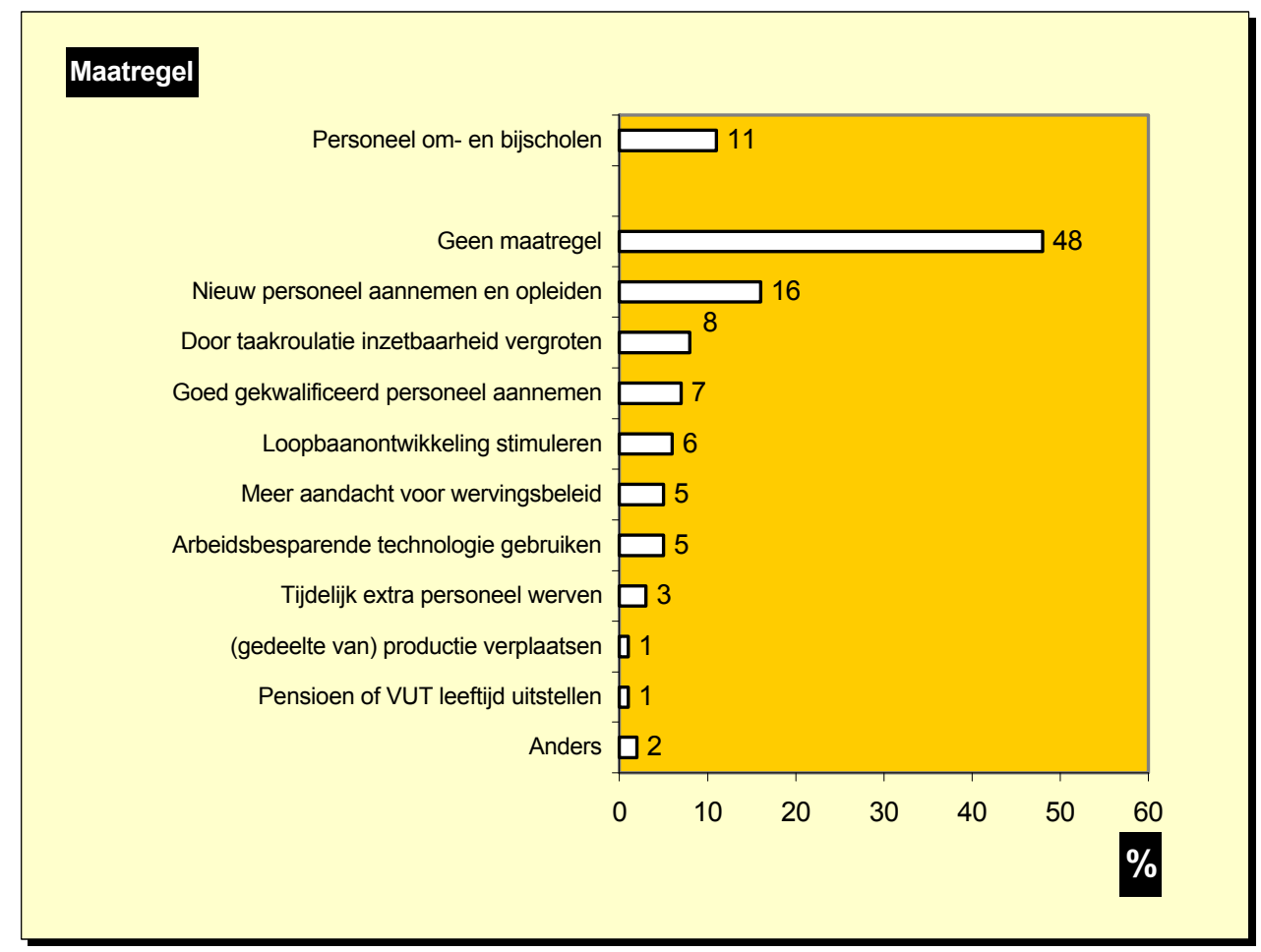

Bron: ROA/werkgeverspanel Metalektro 2003 
Figuur 5.3 laat zien dat $11 \%$ van de bedrijven met problemen bij de vervanging van gepensioneerd technisch personeel voor de om- en bijscholing van het eigen personeel opteert. Daarnaast neemt $16 \%$ nieuwe werknemers aan die ze vervolgens in het bedrijf opleiden. Voor de wervingsoptie (het aannemen van nieuw, gekwalificeerd personeel) kiest slechts $7 \%$ van de bedrijven met problemen. Andere maatregelen die bedrijven inzetten om vervangingsproblemen tegen te gaan zijn het vergoten van de inzetbaarheid van werknemers door taakroulatie $(8 \%)$, het stimuleren van de loopbaanontwikkeling van werknemers $(6 \%)$, meer aandacht besteden aan het wervingsbeleid (5\%) en gebruikmaken van arbeidsbesparende technologie (5\%).

Opvallend is dat bijna de helft van de bedrijven met problemen bij de vervanging van gepensioneerd technisch personeel helemaal geen maatregelen neemt om met deze problemen om te gaan. In 2002 was het percentage bedrijven dat geen maatregelen nam een stuk lager: $35 \%$. Met name bedrijven die te maken hebben met een inkrimping van hun personeelsbestand, nemen vaak geen maatregelen. Hieruit blijkt dat bedrijven in de slechtere economische situatie hun prioriteiten hebben bijgesteld en daarom minder aandacht konden geven aan het nemen van maatregelen om met de problemen met de vervanging van gepensioneerd personeel om te gaan. Ook laten veel bedrijven gepensioneerden afvloeien om gedwongen ontslagen te voorkomen.

\subsection{Scholing in de Metalektro}

Tabel 5.5 geeft aan dat verreweg de meeste Metalektrobedrijven scholing aanbieden. In $78 \%$ van de bedrijven worden cursussen gevolgd die door het eigen bedrijf georganiseerd worden, terwijl in $84 \%$ van de bedrijven het personeel aan externe cursussen deelneemt. Het is opvallend dat deze percentages ongeveer gelijk zijn aan die in 2002, toen het in veel bedrijven economisch gezien nog wat beter ging. Het percentage bedrijven waar technisch personeel aan interne cursussen deelneemt is iets toegenomen, terwijl het percentage bedrijven waar externe cursussen gevolgd worden iets is gedaald. Wellicht zijn externe cursussen duurder dan cursussen die door het bedrijf zelf georganiseerd worden, en letten bedrijven in economisch minder gunstige tijden met name op dit 'out-of-pocket' kostenaspect. Opvallend in dit opzicht is dat bedrijven die met een krimpende werkgelegenheid te maken hebben, net zo vaak cursussen aan hun technisch personeel aanbieden dan bedrijven met een stabiele of zelfs stijgende werkgelegenheid.

Tabel 5.5

Percentage bedrijven en technisch personeel met interne en externe cursusparticipatie in 2002 en 2003

\begin{tabular}{lcccc}
\hline Cursusparticipatie & \multicolumn{2}{c}{2002} & \multicolumn{2}{c}{2003} \\
& $\begin{array}{c}\text { Intern } \\
\%\end{array}$ & $\begin{array}{c}\text { Extern } \\
\%\end{array}$ & $\begin{array}{c}\text { Intern } \\
\%\end{array}$ & $\begin{array}{c}\text { Extern } \\
\%\end{array}$ \\
\hline Bedrijven & 76 & 89 & 78 & 84 \\
Technisch personeel $^{\mathrm{a}}$ & 13 & 14 & 22 & 16
\end{tabular}

${ }^{a}$ Het betreft hier het aandeel technische werknemers op het totaal aantal werknemers in het bedrijf

Bron: ROA/Werkgeverspanel Metalektro 2002 en 2003 
Kijken we vervolgens naar het percentage technisch personeel dat in 2003 een interne of externe cursus volgde, dan zien we dat er gemiddeld meer technische werknemers per bedrijf aan cursussen deelnemen dan in 2002. Dit verschil is met name zichtbaar bij de participatie in interne cursussen. In 2003 volgde $22 \%$ van de technische werknemers een cursus die door het bedrijf zelf georganiseerd werd. In 2002 was dit 13\%. Er zijn op dit punt geen duidelijke verschillen tussen kleine en grote bedrijven of tussen bedrijven uit verschillende sectoren binnen de Metalektro. Wat de externe cursussen betreft, is het verschil tussen 2002 en 2003 veel kleiner: $16 \%$ van het technisch personeel volgde in 2003 een externe cursus, tegenover $14 \%$ in 2002. Opvallend is wel dat in bedrijven die met een krimpende werkgelegenheid te maken hebben, technische werknemers beduidend minder externe cursussen volgen (gemiddeld $8 \%$ ) dan in bedrijven met een stabiele of stijgende werkgelegenheid (gemiddeld 24\%). Ook zijn er regionale verschillen: in de regio Oost Nederland nemen meer technische werknemers aan externe cursussen deel, terwijl in de regio's West en Rijndelta dit aantal kleiner is. In totaal namen er in 200340.400 technische werknemers aan een interne cursus deel en 46.200 aan een externe cursus.

Vergeleken met andere bedrijfssectoren, scoort de Metalektro overigens vrij gemiddeld wat de cursusparticipatie van het personeel betreft. ${ }^{13}$ In de chemie-industrie en de overige industrie nemen beduidend minder werknemers aan scholing deel; in de energiesector en het bank- en verzekeringswezen wordt er echter meer scholing gevolgd.

\section{Welke cursussen worden er gevolgd?}

Figuur 5.4 laat zien dat cursussen op het gebied van vaktechnische vaardigheden het meest populair zijn. In maar liefst $80 \%$ van de bedrijven worden dergelijke cursussen intern door het technisch personeel gevolgd. Aan externe vaktechnische cursussen wordt zelfs in $91 \%$ van de bedrijven deelgenomen. Daarnaast worden er veel IT-cursussen gevolgd. Deze cursussen waren ook in 2002 al populair. In 2003 worden er in duidelijk meer bedrijven interne en externe cursussen op het gebied van probleemoplossend vermogen gevolgd. We zagen al eerder in dit hoofdstuk dat dit voor veel bedrijven in de Metalektro een belangrijk aandachtspunt is: het technisch personeel kampt met tekorten in probleemoplossend vermogen terwijl deze competentie steeds belangrijker wordt voor het goed functioneren. Uit tabel 5.2 bleek dat er daarnaast ook relatief vaak sprake is van competentietekorten op het terrein van de communicatieve vaardigheden van het technisch personeel. Het is opmerkelijk dat bedrijven hun personeel niet vaker cursussen op dit terrein laten volgen dan in 2002.

Vergeleken met 2002, worden er in 2003 in minder bedrijven externe cursussen gevolgd op het gebied van leidinggeven en zelfstandig werken. Het aantal bedrijven dat het technisch personeel interne cursussen op dit gebied laat volgen is echter niet veranderd. Dit lijkt erop te wijzen dat bedrijven in economisch minder gunstige tijden 
met name op het gebied van deze competenties kritisch naar de deelname aan externe cursussen kijken.

Figuur 5.4

Interne en externe cursusparticipatie van het technisch personeel in 2003

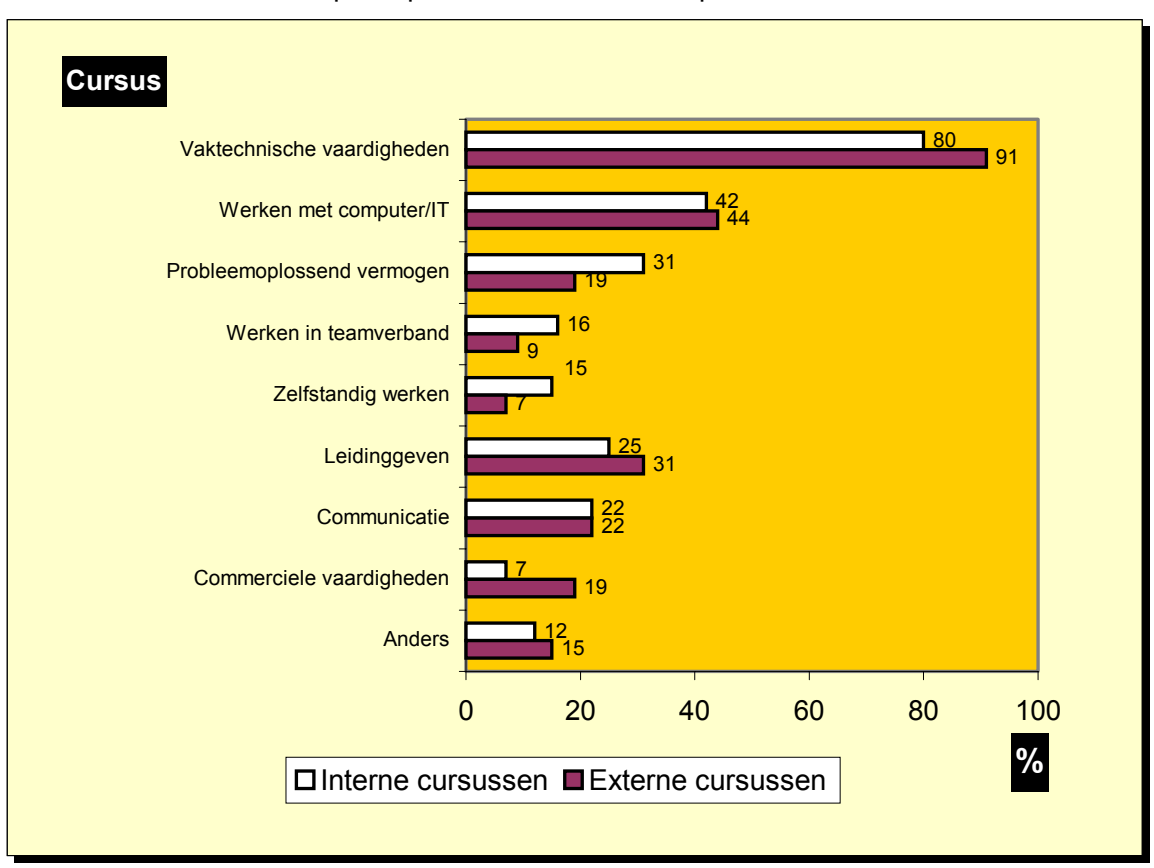

Bron: ROA/werkgeverspanel Metalektro 2003

Over het algemeen volgt het technisch personeel van grote bedrijven vaker cursussen dan de technici die werkzaam zijn in kleine bedrijven. Dit is met name het geval bij interne cursussen op het gebied van probleemoplossend vermogen, leidinggeven en communicatie en bij externe cursussen op het gebied van IT, leidinggeven en commerciële vaardigheden. Technici in middelgrote bedrijven (tussen de 100 en 250 medewerkers) nemen vaker deel aan interne vaktechnische cursussen en aan externe cursussen gericht op het werken in teamverband en communicatieve vaardigheden. Daarnaast zijn er enkele sectorverschillen in externe cursusparticipatie. Technici in de machine-industrie volgen vaker cursussen op het gebied van vaktechnische vaardigheden en werken in teamverband, terwijl het technisch personeel in de sector metaalproducten vaker cursussen volgt die te maken hebben met zelfstandig werken en communicatie.

\section{Redenen van cursusparticipatie}

Is er bij de scholing van het technisch personeel vooral sprake van bijscholing of van omscholing? Bij bijscholing gaat het om aanvullende scholing die nodig is voor het adequaat vervullen van de huidige functie. Omscholing heeft daarentegen betrekking op het opleiden voor een andere functie dan waar de werknemer oorspronkelijk toe opgeleid is. In 2003 werd er in 96\% van de Metalektrobedrijven aan bijscholing 
gedaan en in $39 \%$ van de bedrijven aan omscholing. Gemiddeld genomen werd in de Metalektro 3\% van het technisch personeel omgeschoold en $31 \%$ bijgeschoold; $66 \%$ van het technisch personeel volgde geen scholing.

Naast dit vrij algemene onderscheid in om- en bijscholing kunnen we een aantal specifieke doelen onderscheiden waarom het technisch personeel in de Metalektro aan cursussen deelneemt. Tabel 5.6 laat zien dat cursussen met name gevolgd worden om de bestaande vaardigheden in de huidige functie te verbeteren. Daarnaast wordt er door technici aan cursussen deelgenomen om nieuwe vaardigheden voor hun huidige functie aan te leren en om hun inzetbaarheid voor andere taken te vergroten. Het aanleren van nieuwe vaardigheden voor de verdere loopbaan speelt bij het volgen van cursussen veel minder vaak een rol. Overigens worden in kleine bedrijven vaker cursussen gevolgd om nieuwe vaardigheden voor de huidige functie aan te leren, terwijl in middelgrote bedrijven het aanleren van nieuwe vaardigheden voor de verdere loopbaan wat vaker de reden is voor het volgen van een cursus.

Tabel 5.6

Doelen die een rol spelen bij de cursusparticipatie van het technisch personeel in 2003

\begin{tabular}{lccc}
\hline Doel & $\begin{array}{c}\text { Zeer sterk } \\
\text { van } \\
\text { toepassing } \\
\%\end{array}$ & $\begin{array}{c}\text { Enigszins } \\
\text { van } \\
\text { toepassing } \\
\%\end{array}$ & $\begin{array}{c}\text { Niet } \\
\text { van } \\
\text { toepassing } \\
\%\end{array}$ \\
\hline Verbeteren bestaande vaardigheden & 68 & 26 & 5 \\
Aanleren nieuwe vaardigheden voor huidige functie & 51 & 45 & 3 \\
Vergroten van de inzetbaarheid & 50 & 42 & 8 \\
Aanleren vaardigheden voor de verdere loopbaan & 18 & 52 & 30 \\
\hline
\end{tabular}

Bron: ROA/Werkgeverspanel Metalektro 2003

Over het algemeen worden interne cursussen minder vaak gevolgd om nieuwe vaardigheden voor de verdere loopbaan aan te leren. Kennelijk hebben bedrijven in dat geval niet de expertise in huis om deze cursussen aan te bieden. Externe cursussen worden minder vaak gevolgd om bestaande vaardigheden te verbeteren of de inzetbaarheid van werknemers te vergroten.

\section{Kosten van scholing}

Scholing van werknemers brengt kosten met zich mee. Hierbij moet men niet alleen denken aan de kosten van de cursussen zelf, maar ook aan de tijd die de werknemers aan scholing besteden, waardoor ze niet inzetbaar zijn in het productieproces. Figuur 5.5 laat zien dat van alle cursussen die er in de Metalektro gevolgd worden, de helft in de tijd van het bedrijf gevolgd wordt. $17 \%$ van de cursussen wordt zowel in de tijd van het bedrijf als in de tijd van de werknemer zelf gevolgd. Daarentegen wordt eenderde van de cursussen geheel in de tijd van de werknemer gevolgd. Dit blijkt met name bij bedrijven in de machine-industrie het geval te zijn. Verschillen tussen grote en kleine bedrijven en regionale verschillen zijn niet gevonden. 
Figuur 5.5

Gemiddeld percentage van het aantal door het technisch personeel gevolgde cursussen dat gevolgd wordt in de tijd van het bedrijf, de werknemer of beide in 2003

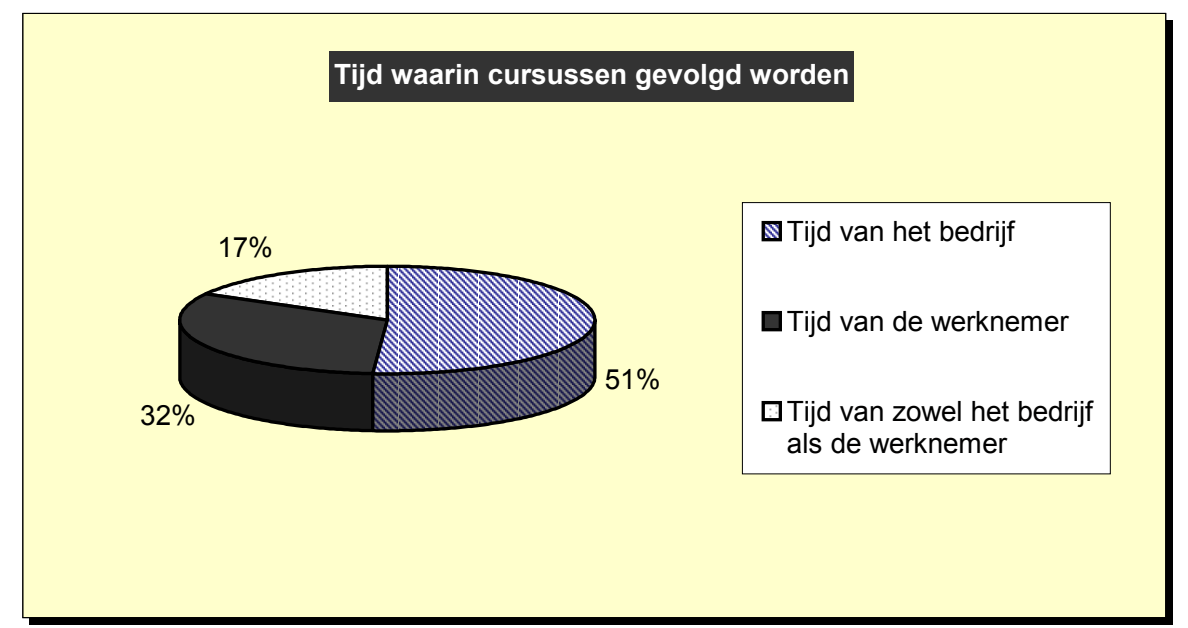

Bron: ROA/Werkgeverspanel Metalektro 2003

Aan de bedrijven is ook gevraagd hoe groot de totale directe kosten van cursusparticipatie zijn. Dit zijn de 'out of pocket' kosten - inclusief eventuele subsidies - van de door het technisch personeel gevolgde interne en externe cursussen. Tabel 5.7 laat zien dat deze kosten gemiddeld zo'n $€ 65.000$,- per bedrijf bedragen. Voor de hele Metalektro betekent dit dat er in 2002 in totaal bijna $€ 75$ miljoen aan cursussen besteed werd. Overigens komt $98 \%$ van de cursuskosten voor rekening van het bedrijf. Slechts $2 \%$ wordt door de werknemer betaald.

Tabel 5.7

Totale directe kosten van cursussen voor het technisch personeel in 2002

Kosten

Totale kosten in de Metalektro

Gemiddelde kosten per bedrijf

74.793 .000

Gemiddelde kosten per getrainde werknemer

65.000

2.100

Bron: ROA/Werkgeverspanel Metalektro 2003

Deze bedragen kunnen ook worden omgerekend naar de gemiddelde kosten per werknemer die aan cursussen heeft deelgenomen. Het blijkt dat er in 2002 gemiddeld $€ 2.100$,- per getrainde technische werknemer aan cursussen is uitgegeven. Daarbij zijn er weinig verschillen tussen grote of kleine bedrijven, bedrijven uit verschillende sectoren in de Metalektro of uit verschillende regio's en bedrijven die aan interne of externe cursussen doen. 


\subsection{Het bevorderen van scholing}

We hebben in het voorgaande gezien dat veel bedrijven in de Metalektro scholing van groot belang vinden en daarom cursussen aan het technisch personeel aanbieden. Toch zou de scholing in de Metalektro nog verder bevorderd kunnen worden. Immers, tweederde van het technisch personeel heeft in 2002 helemaal geen scholing gevolgd. Er zijn verschillende manieren om de cursusparticipatie te bevorderen. Daarbij kan men denken aan:

- het weghalen van belemmeringen die de bedrijven in de Metalektro ondervinden bij de cursusparticipatie van het technisch personeel;

- de subsidies en financieringsbronnen die bedrijven kunnen gebruiken bij het financieren van cursussen;

- het inzetten van HRM-instrumenten om de cursusparticipatie te bevorderen.

\section{Belemmerende factoren bij cursusparticipatie}

Tweederde van de bedrijven in de Metalektro ondervindt belemmeringen bij de cursusparticipatie van het technisch personeel. Figuur 5.6 laat zien dat het feit dat cursussen veel geld kosten (44\%) het meest genoemd wordt. In 2002 gaf slechts $28 \%$ van de bedrijven aan dat dit een belemmering voor cursusparticipatie was. Hieruit blijkt duidelijk dat het kostenaspect een grotere belemmering is gaan vormen voor de cursusparticipatie van het technisch personeel. Andere belemmeringen die veel genoemd worden zijn 'cursussen kosten veel tijd' $(41 \%)$, 'cursussen vinden op een ongunstig tijdstip plaats' $(22 \%)$ en 'het personeel is niet geïnteresseerd in cursussen' (19\%).

Figuur 5.6

Belemmerende factoren bij de cursusparticipatie van het technisch personeel in 2003

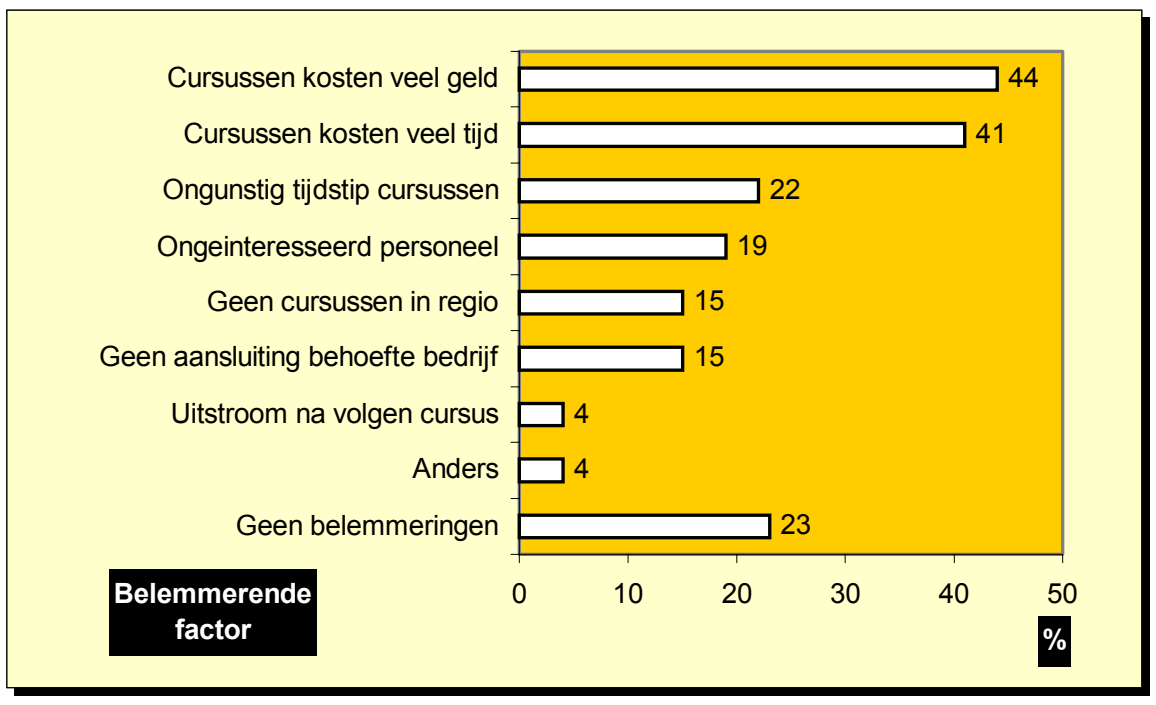

Bron: ROA/werkgeverspanel 2003 
Opvallend is dat kleine bedrijven aangeven minder last te hebben van belemmerende factoren bij de cursusparticipatie van hun technisch personeel. Wel melden zij vaker dan grote bedrijven dat hun personeel niet geïnteresseerd is in het volgen van cursussen. Dit geeft aan dat er in kleine bedrijven vaak geen goede opleidingscultuur is. Ook bedrijven in Oost en Noord Nederland geven vaker aan dat hun personeel niet geïnteresseerd is in het volgen van cursussen, terwijl dit juist veel minder een rol speelt in bedrijven in West en Zuidoost Nederland.

Overigens leiden deze belemmeringen over het algemeen niet tot een lagere cursusparticipatie van het technisch personeel. Wel blijkt het zo te zijn dat wanneer werknemers niet geïnteresseerd zijn in het volgen van cursussen, er minder vaak interne cursussen gevolgd worden. Figuur 5.7 laat zien dat bijna de helft van de bedrijven in de Metalektro de scholingsbereidheid van het technisch personeel 'niet groot maar ook niet klein' noemen. $11 \%$ van de bedrijven noemt de scholingsbereidheid klein en $2 \%$ zeer klein. Met name in de metaalproductensector wordt de scholingsbereidheid van het technisch personeel lager ingeschat.

Figuur 5.7

Scholingsbereid van het technisch personeel volgens bedrijven in 2003

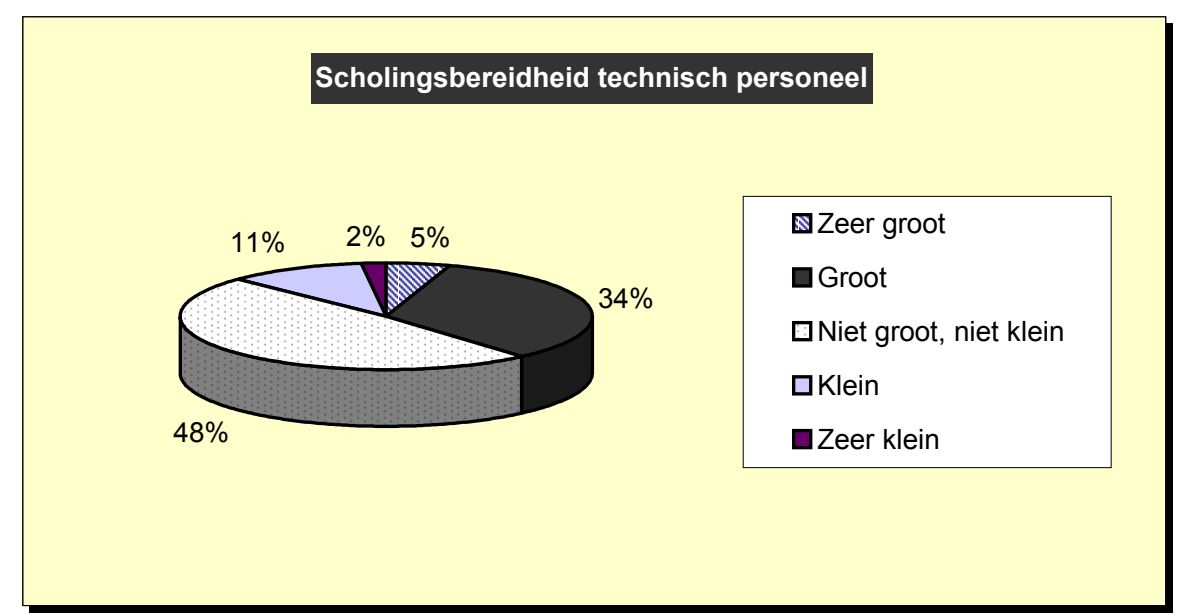

Bron: ROA/Werkgeverspanel Metalektro 2003

Tabel 5.8 geeft aan dat meer dan eenderde van de bedrijven vindt dat het technisch personeel zelf het initiatief voor hun bijscholing moet nemen. Bedrijven in de sector metaalproducten zijn het hier wat minder vaak mee eens, terwijl bedrijven in de machine-industrie vaker vinden dat het personeel het initiatief voor hun bijscholing nemen. Initiatief nemen is vaak nog iets anders dan de verantwoordelijkheid voor iets hebben. Dit is ook het geval bij de scholingsparticipatie. Zo vindt $45 \%$ van de bedrijven dat de verantwoordelijkheid voor bijscholing bij het technisch personeel ligt. Een aantal bedrijven is dus wel bereid het initiatief te nemen voor bijscholingsactiviteiten, maar vindt dat de uiteindelijke verantwoordelijkheid van de scholing bij de werknemers zelf ligt. 
Tabel 5.8

Beoordeling van stellingen "Technisch personeel moet zelf het initiatief voor hun bijscholing nemen" en "Technisch personeel moet zelf de verantwoordelijkheid voor hun bijscholing nemen"

\begin{tabular}{lcc}
\hline Beoordeling & $\begin{array}{c}\text { Initiatief } \\
\%\end{array}$ & $\begin{array}{c}\text { Verantwoordelijkheid } \\
\%\end{array}$ \\
\hline (Geheel) mee oneens & 25 & 40 \\
Niet mee eens, niet mee oneens & 39 & 15 \\
(Geheel) mee eens & 37 & 45 \\
\hline
\end{tabular}

Bron: ROA/Werkgeverspanel Metalektro 2003

\section{Subsidies en financieringsbronnen}

Zoals we al eerder melden, kost scholing voor bedrijven in de Metalektro in totaal bijna 75 miljoen euro op jaarbasis. Nu bestaan er verschillende regelingen en subsidies die de scholingskosten voor bedrijven beperken en zo de scholing van werknemers stimuleren. Zo maakte in 2002 85\% van de bedrijven gebruik van de regeling voor scholingsaftrek van de fiscus. Deze regeling houdt in dat bedrijven naast het verminderen van de kosten voor scholing op de bedrijfswinst - nog eens $20 \%$ van deze kosten extra van de fiscale winst kunnen aftrekken. Voor bedrijven met een klein scholingsbudget of met oudere werknemers die scholing volgen, gold nog een additionele scholingsaftrek van respectievelijk $20 \%$ en $40 \%$. Deze mogelijkheid tot scholingsaftrek is zowel door kleine als door grote bedrijven veel gebruikt.

Tabel 5.9 geeft een overzicht van de externe financieringsbronnen die Metalektrobedrijven in 2002 hebben gebruikt bij de bekostiging van de cursussen voor het technisch personeel. Het merendeel van de bedrijven $(60 \%)$ heeft subsidies van de Stichting $A+O$ ontvangen. Uit gegevens van de Stichting $A+O$ blijkt dat ruim de helft van de bedrijven (55\%) in 2003 financiering voor ingediende employabilityplannen ontving; $15 \%$ van de bedrijven ontving een bijdrage voor BOL-stagiaires en $15 \%$ van de bedrijven ontving een bijdrage voor BBL-leerlingen vanuit de huidige CAO $(10 \%$ van de bedrijven kreeg nog financiering voor BBL-leerlingen vanuit de oude CAO). Bedrijven kunnen gebruik maken van verschillende regelingen.

Daarnaast heeft $5 \%$ van de bedrijven gebruik gemaakt van subsidies van het Europees Sociaal Fonds (ESF), terwijl 7\% nog andere subsidies heeft verkregen, zoals subsidies van het Europese Stimulus programma, het Gemeenschappelijk BegeleidingsInstituut Ondernemingsraden (GBIO) en andere opleidings- en ontwikkelingsfondsen zoals de O\&O fondsen voor de elektrotechniek (OFE) en installatietechniek (OLC). In de Metalektro wordt er overigens, vergeleken met andere bedrijfssectoren, veel gebruik gemaakt van de beschikbare O\&O subsidies. ${ }^{14}$ 
Tabel 5.9

Gebruik van externe financieringsbronnen bij de bekostiging van cursussen voor het technisch personeel in 2002*

Externe financieringsbron

Subsidie Stichting $\mathrm{A}+\mathrm{O}$

ESF subsidies

Andere subsidies

Geen externe financieringsbron

* De verschillende percentages staan los van elkaar en hoeven dus niet op te tellen tot $100 \%$. Bron: ROA/Werkgeverspanel Metalektro 2003

lets meer dan eenderde van de bedrijven maakt daarentegen geen gebruik van externe financieringsbronnen bij de bekostiging van de cursussen voor het technisch personeel. Het blijkt dat kleine bedrijven minder vaak van subsidies gebruik maken dan grote bedrijven. Wellicht beschikken zij niet over de juiste resources in de vorm van goede informatie en beschikbaar personeel om hun aanvragen in te dienen. Daarnaast loont het aanvragen van subsidies ook meer voor grote bedrijven, omdat het om grotere bedragen gaat.

Figuur 5.8

Gemiddeld percentage van de totale scholingskosten door externe financieringsbronnen bekostigd in 2002

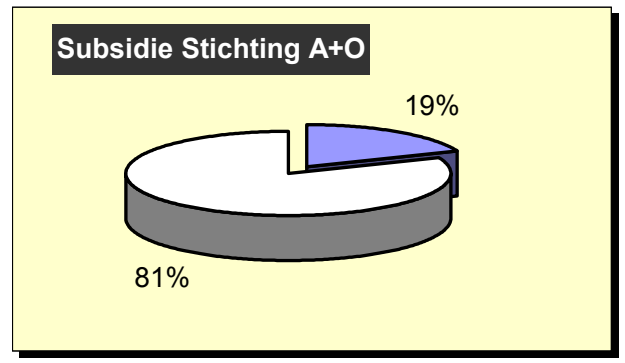

\section{ESF subsidie}
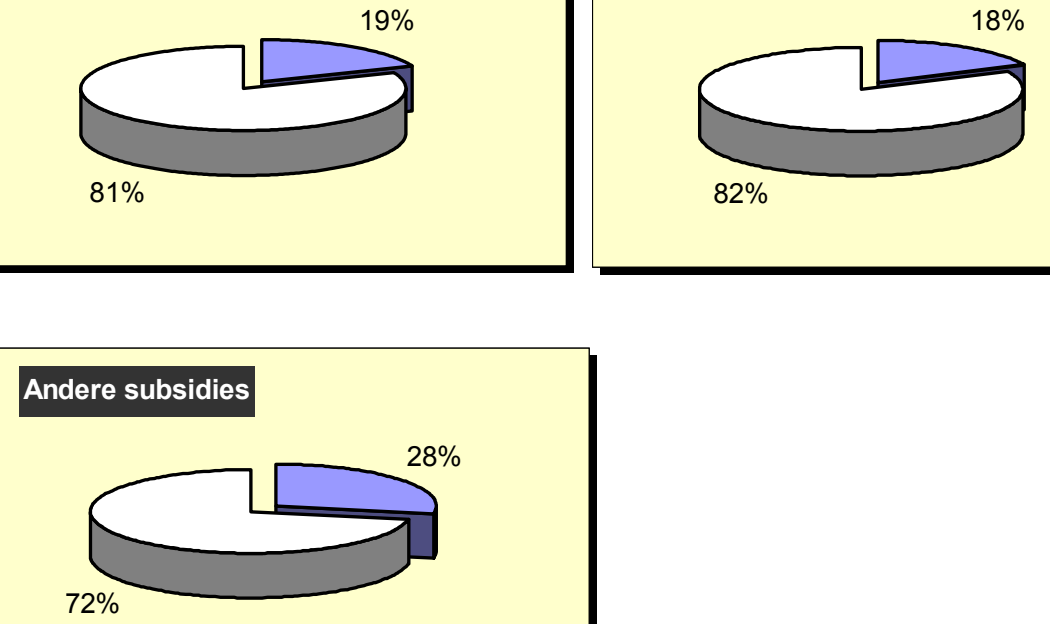

Bron: ROA/Werkgeverspanel Metalektro 2003

Figuur 5.8 laat zien dat subsidies van de Stichting $A+O$ in bedrijven die deze subsidies ontvangen hebben, gemiddeld bijna $20 \%$ van de totale scholingskosten dekken. Hetzelfde geldt voor de ESF subsidies: bedrijven die deze subsidies krijgen, 
bekostigen hiermee $18 \%$ van hun totale scholingskosten. De andere subsidies leveren iets meer op, gemiddeld zo'n $28 \%$ van de gemaakte totale scholingskosten. Het zijn met name de kleine bedrijven die, wanneer ze erin slagen deze andere scholingssubsidies aan te werven, een groter deel van hun scholingskosten door deze subsidies gefinancierd krijgen.

In hoeverre heeft het gebruik van deze externe financieringsbronnen nu ook echt geleid tot een toename van de cursusparticipatie van het technisch personeel? Tabel 5.10 laat zien wat de bedrijven in de Metalektro hier zelf van denken. $57 \%$ van de bedrijven die subsidies van de Stichting $A+O$ heeft ontvangen, vindt dat dit een positief effect heeft gehad op het aantal cursussen dat door het technisch personeel is gevolgd. De ESF subsidies blijken nog vaker van belang te zijn bij het daadwerkelijk kunnen volgen van cursussen. Maar liefst $80 \%$ van de bedrijven geeft aan dat deze subsidies tot meer cursussen hebben geleid. Ook de andere subsidies hebben volgens veel bedrijven een positief effect op de cursusparticipatie van hun technisch personeel gehad. Het gaat dan meestal om externe cursussen. Daarnaast lijken met name de subsidies van de Stichting $A+O$ de externe cursusparticipatie te verhogen. De invloed van subsidies en externe financieringsbronnen op cursussen die door het bedrijf zelf georganiseerd worden is erg klein.

Tabel 5.10

Positief effect van externe financieringsbronnen op het aantal door het technisch personeel gevolgde cursussen in 2002*

Externe financieringsbron $\quad \begin{gathered}\text { Positief effect } \\ \%\end{gathered}$

$\begin{array}{lr}\text { Subsidie Stichting A+O } & 57 \\ \text { ESF subsidies } & 80 \\ \text { Andere subsidies } & 88\end{array}$

\footnotetext{
${ }^{*}$ De verschillende percentages staan los van elkaar en hoeven dus niet op te tellen tot $100 \%$. Bron: ROA/Werkgeverspanel Metalektro 2003

\section{Inzetten van HRM-instrumenten}

Bedrijven kunnen de scholing van hun werknemers ook bevorderen door een gericht Human Resource Management (HRM) beleid te voeren. Kort gezegd is HRM-beleid erop gericht de inzet van medewerkers te optimaliseren. Hierbij hoort ook het op peil houden van de kennis en vaardigheden van het personeel en het uitbreiden van het 'menselijk kapitaal' in het bedrijf. In hoofdstuk 6 zal dieper worden ingegaan op het gevoerde HRM-beleid in de bedrijven in de Metalektro. Hier willen we ingaan op de rol die HRM-instrumenten kunnen spelen bij het bevorderen van de scholing voor het technisch personeel. 
Onderzocht is of bedrijven die bepaalde HRM-instrumenten inzetten, hun technisch personeel vaker en meer aan interne en externe cursussen laten deelnemen dan bedrijven die dit niet doen. We kijken daarbij naar de volgende HRM-instrumenten:

- opleidingsfaciliteiten

- bedrijfsopleidingsplannen (BOP)

- persoonlijke opleidingsplannen (POP)

- competentie- of vaardighedenmatrix

- erkenning verworven competenties (EVC)

- loopbaanontwikkeling

- functieroulatie

- functioneringsgesprekken

- beoordelingsgesprekken

- scholingsgesprekken

- geregeld werkoverleg

- loopbaanadviescentrum of mobiliteitscentrum.

Figuur 5.9 laat zien welke van deze HRM-instrumenten ervoor kunnen zorgen dat bedrijven in de Metalektro aan cursusparticipatie gaan doen. Het blijkt dat bedrijven die een bedrijfsopleidingsplan (BOP) hebben vaker interne cursussen aanbieden dan bedrijven die geen BOP hebben. Het schriftelijk vastleggen van alle geplande, functiegerichte opleidingsactiviteiten in relatie tot het beleid van de onderneming leidt er dus toe dat er ook daadwerkelijk in meer bedrijven scholing gevolgd wordt. Ook carrièreplanning en scholingsgesprekken kunnen de interne cursusparticipatie op bedrijfsniveau bevorderen. Niet alleen de interne, maar ook de externe cursusparticipatie kan op bedrijfsniveau bevorderd worden door de inzet van een bedrijfsopleidingsplan en door carrièreplanning.

Figuur 5.9

HRM-instrumenten en het bevorderen van de interne en externe cursusparticipatie op bedrijfsniveau

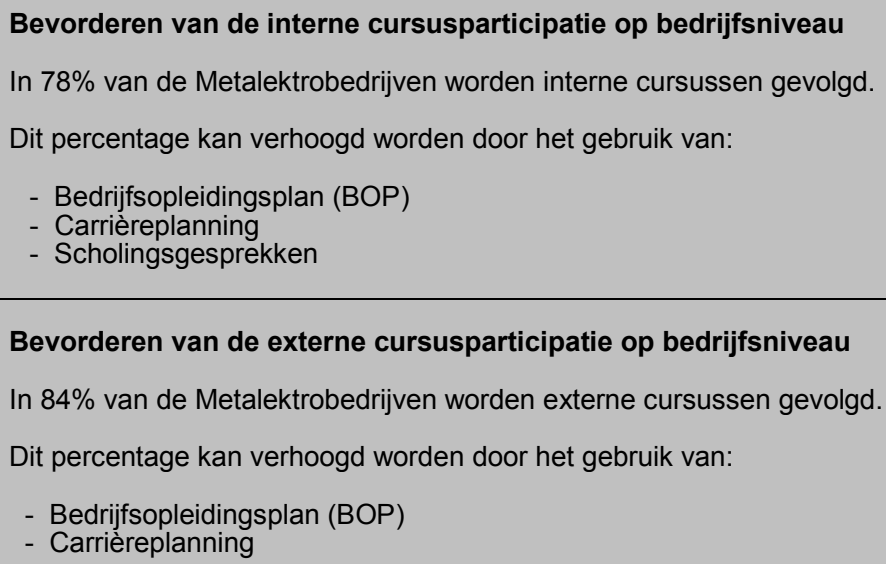

Bevorderen van de externe cursusparticipatie op bedrijfsniveau

In $84 \%$ van de Metalektrobedrijven worden externe cursussen gevolgd.

Dit percentage kan verhoogd worden door het gebruik van:

- Bedrijfsopleidingsplan (BOP)

- Carrièreplanning

Bron: ROA/Werkgeverspanel Metalektro 2003 
Wanneer een bedrijf eenmaal aan scholing doet, kan de cursusparticipatie van het technisch personeel binnen het bedrijf bevorderd worden. Figuur 5.10 laat zien dat in een bedrijf meer technische werknemers aan interne cursussen deelnemen wanneer er sprake is van scholingsgesprekken, persoonlijke ontwikkelingsplannen (POP), carrièreplanning of functieroulatie, of wanneer er gebruik gemaakt wordt van een competentie- of vaardighedenmatrix. Daarnaast is carrièreplanning ook een belangrijk instrument om meer technische werknemers aan externe cursussen te laten deelnemen.

Figuur 5.10

HRM-instrumenten en het bevorderen van de interne en externe cursusparticipatie van technische werknemers in het bedrijf

\section{Bevorderen van de interne cursusparticipatie van technici}

Gemiddeld neemt 22\% van het technisch personeel aan interne cursussen deel.

Dit percentage kan verhoogd worden door het gebruik van:

- Scholingsgesprekken

- Persoonlijk ontwikkelingsplan (POP)

- Competentie- of vaardighedenmatrix

Carrièreplanning

- Functieroulatie

\section{Bevorderen van de externe cursusparticipatie van technici}

Gemiddeld neemt $16 \%$ van het technisch personeel aan externe cursussen deel.

Dit percentage kan verhoogd worden door het gebruik van:

- Carrièreplanning

Bron: ROA/Werkgeverspanel Metalektro 2003 



\section{HRM-beleid en employability}

Net zoals dat tegenwoordig voor veel andere sectoren in de Nederlandse Economie het geval is, speelt het Human Resource Management (HRM) ook in de Metalektro een centrale rol bij het realiseren van de bedrijfsdoelstellingen. In dit hoofdstuk zal worden ingegaan op de wisselwerking tussen een goed HRM-beleid en de employability van het personeel. Waarom is een gedegen HRM-beleid zo belangrijk? Hoe geven de Metalektrobedrijven hun HRM-beleid vorm? Wat zijn daarbij belangrijke HRM-instrumenten? Hoe is het gesteld met de inzetbaarheid van het personeel in de Metalektro? Wat is de relatie tussen het gebruik van bepaalde HRMinstrumenten en de inzetbaarheid. Het hoofdstuk zal afsluiten met een vergelijking van de Metalektro met twee andere sectoren op het vlak van het gebruik van enkele centrale HRM instrumenten om het HRM-beleid in de Metalektro in een wat bredere context te plaatsen.

\subsection{Het belang van een goed HRM-beleid}

Het Human Resource Management speelt tegenwoordig in veel bedrijven een belangrijke rol in het strategisch beleid van de onderneming. In een kenniseconomie heeft de kwaliteit van het personeel een doorslaggevende betekenis voor de concurrentiekracht van bedrijven, waardoor er veel aandacht is voor het beleid rondom de ontwikkeling, de inzet en het behoud van het personeel. Ook in de Metalektro is dit het geval. De complexe structuur van veel productieprocessen in de Metalektrobedrijven en de sterke nationale of internationale concurrentie vereisen een personeelsbestand dat zowel op het gebied van kennis als inzetbaarheid up-to-date is.

Het HRM-beleid kan de bedrijfsprestaties op verschillende manieren positief beïnvloeden. Een HRM-beleid dat gericht is op het opleiden van werknemers zorgt voor de kennis en vaardigheden die nodig zijn om de productie en de veranderingen van de productieprocessen efficiënt te laten verlopen. Goed opgeleid personeel dat beschikt over de competenties die nodig zijn voor het maken van producten van een hoogwaardige kwaliteit is bovendien cruciaal voor de concurrentiekracht van de bedrijven in de Nederlandse Metalektro-industrie. Ook het monitoren en bevorderen van de inzetbaarheid van het personeel, bijvoorbeeld door het bijhouden van competentie-matrices of het stimuleren van functieroulatie, is voor veel bedrijven een belangrijk middel om optimaal te presteren. Daarnaast is het HRM-beleid van grote betekenis voor het behoud van het personeel. Instrumenten zoals carrièreplanning, persoonlijke ontwikkelingsplannen, scholing en functieroulatie kunnen ervoor zorgen dat werknemers de kans krijgen om zich tijdens hun loopbaan verder te ontwikkelen en door te groeien. De positieve effecten hiervan op de arbeidstevredenheid kunnen helpen om de ongewenste personeelsuitstroom te beperken. Het HRM-beleid is ook belangrijk voor de werving van nieuw personeel. Bedrijven die veel aandacht besteden aan HRM-beleid laten zien dat zij hun werknemers veel te bieden hebben op het gebied van opleiding en ontwikkeling en vormen dus aantrekkelijke werkgevers. Hierdoor zal het eenvoudiger worden om geschikt personeel aan te trekken. 
Tabel 6.1

Verandering in aandacht voor het HRM-beleid in 2003 ten opzichte van 2002

Verandering

Minder aandacht

Evenveel aandacht 8

Meer aandacht

Bron: ROA/Werkgeverspanel Metalektro 2003

De meeste Metalektrobedrijven hebben veel aandacht voor hun HRM-beleid. Soms wordt echter gesteld dat er bij een economische teruggang minder aandacht kan zijn voor het HRM beleid als gevolg van de noodzaak tot kostenbesparingen. Voor de bedrijven in de Metalektro blijkt dat echter niet het geval te zijn. Tabel 6.1 laat namelijk zien dat ondanks de recessie de huidige aandacht voor het HRM naar eigen zeggen op peil blijft. Ruim negen op de tien bedrijven had in 2003 evenveel of zelfs meer aandacht voor het HRM beleid dan in het jaar daarvoor.

\subsection{HRM in de Metalektro}

Tabel 6.2 geeft een overzicht van de HRM-instrumenten die in de Metalektro worden ingezet met betrekking tot het technisch personeel. Er wordt daarbij een onderscheid gemaakt tussen de inzet van instrumenten voor alle technische werknemers en het gebruik van de HRM-instrumenten voor een meerderheid van het technisch personeel. Uit de tabel blijkt dat in bijna zeven op de tien bedrijven met alle technici functioneringsgesprekken, beoordelingsgesprekken en geregeld werkoverleg wordt gevoerd. Ook opleidingsfaciliteiten en bedrijfsopleidingsplannen zijn populair: In meer dan de helft van de bedrijven in de Metalektro worden ze in het kader van het HRMbeleid ingezet. Wel valt het op dat in 2003 minder bedrijven opleidingsfaciliteiten aan alle technisch werknemers aanboden dan in 2002. In 2002 werd nog in ruim $70 \%$ van de bedrijven opleidingsfaciliteiten aan al het technisch personeel aangeboden. In 2003 was dit nog slechts in $61 \%$ van de bedrijven het geval. De evaluatie en planning van scholingsactiviteiten door middel van scholingsgesprekken is echter weer toegenomen van $29 \%$ in 2002 tot $37 \%$ in 2003 . Blijkbaar wordt er vanwege de meer schaarse middelen meer aandacht besteed aan het vinden van passende scholing. Mogelijk worden de investeringen in opleidingen achteraf ook beter geëvalueerd. Deze professionalisering van het HRM-beleid zal het rendement van het opleidingsbeleid waarschijnlijk vergroten.

Slechts één op de acht bedrijven maakt gebruik van persoonlijke ontwikkelingsplannen. Blijkbaar is het op individuele basis vaststellen, analyseren en plannen van opleidingen nog geen gemeengoed geworden. Hoewel nog weinig bedrijven EVC (Erkenning Verworven Competenties) toepassen, is het percentage bedrijven dat dit doet wel verdubbeld: van $2 \%$ in 2002 naar $4 \%$ in 2003 . 
Tabel 6.2

Gebruikte HRM-instrumenten voor het technisch personeel, 2003

\begin{tabular}{lcc}
\hline HRM-instrument & $\begin{array}{c}\text { Voor alle } \\
\text { technische } \\
\text { werknemers } \\
\%\end{array}$ & $\begin{array}{c}\text { Voor een meerderheid } \\
\text { van de technische } \\
\text { werknemers } \\
\%\end{array}$ \\
\hline Opleidingsfaciliteiten & 61 & 19 \\
Bedrijfsopleidingenplan (BOP) & 56 & 12 \\
Persoonlijk Ontwikkelingsplan (POP) & 13 & 13 \\
Competentie- of vaardighedenmatrix & 19 & 13 \\
Erkenning Verworven Competenties (EVC) & 4 & 5 \\
Carrièreplanning & 4 & 3 \\
Functieroulatie & 6 & 22 \\
Functioneringsgesprekken & 72 & 11 \\
Beoordelingsgesprekken & 69 & 17 \\
Scholingsgesprekken & 37 & 22 \\
Geregeld werkoverleg & 63 & 1 \\
Loopbaanadvies/mobiliteitscentrum & 1 & \\
\hline
\end{tabular}

Bron: ROA/Werkgeverspanel Metalektro 2003

De nog geringe aandacht van EVC staat in schril contrast met de constatering dat een aanzienlijk deel van het technisch personeel in de Metalektro niet beschikt over een startkwalificatie van de arbeidsmarkt (zie hoofdstuk 2). Ook is er slechts in erg weinig bedrijven aandacht voor carrièreplanning, terwijl slechts enkele grote bedrijven de beschikking hebben over een eigen loopbaanadvies- of mobiliteitcentrum. Daarentegen is er weer in meer bedrijven aandacht voor de functieroulatie van het technisch personeel, hoewel dit in weinig bedrijven betrekking heeft op al het technisch personeel.

Tabel 6.3

Belangrijkste HRM-instrumenten voor het technisch personeel, 2003*

HRM-instrument

Functioneringsgesprekken

Opleidingsfaciliteiten

Geregeld werkoverleg

Bedrijfsopleidingenplan (BOP)

Beoordelingsgesprekken

Functieroulatie

Persoonlijk Ontwikkelingsplan (POP)

Carrièreplanning

Competentie- of vaardighedenmatrix

Scholingsgesprekken

Erkenning Verworven Competenties (EVC)

Loopbaanadvies/mobiliteitscentrum

${ }^{*}$ De verschillende percentages staan los van elkaar en hoeven dus niet op te tellen tot $100 \%$. Bron: ROA/Werkgeverspanel Metalektro 2003

In tabel 6.3 wordt nagegaan wat bedrijven de belangrijkste HRM-instrumenten vinden in het kader van de employability van hun technisch personeel. Twee instrumenten 
blijken de basics van het HRM-beleid in de Metalektro te vormen: functioneringsgesprekken en het aanbieden van opleidingsfaciliteiten. $61 \%$ van de bedrijven vindt functioneringsgesprekken het belangrijkste HRM-instrument, terwijl 59\% van de bedrijven het aanbieden van opleidingsfaciliteiten erg belangrijk vindt. Daarnaast vindt circa $40 \%$ van de bedrijven het houden van geregeld werkoverleg en het hebben van een bedrijfsopleidingsplan belangrijke HRM-instrumenten.

\subsection{De relatie met employability}

De effectiviteit van het HRM-beleid hangt niet alleen af van de inspanningen van het bedrijf, maar ook van de inspanningen van de werknemers. Een manier om te kijken naar de bijdrage die het personeel aan de effectiviteit van het HRM-beleid levert, is door het in kaart brengen van de employability van het technisch personeel. Daarbij verstaan we onder employability: het vermogen en de bereidheid om aantrekkelijk te zijn voor de arbeidsmarkt, door te reageren en te anticiperen op veranderingen in arbeidstaken en werkomgeving". ${ }^{15}$

De employability van werkenden is echter niet alleen de verantwoordelijkheid van de werknemer zelf. Zoals tabel 6.4 laat zien vinden vrijwel alle bedrijven in de Metalektro dat er bij de employability van het personeel sprake is van een gedeelde verantwoordelijkheid tussen werknemers en bedrijven.

Tabel 6.4

Verantwoordelijkheid voor employability, 2003

Verantwoordelijkheid ligt bij

De werkgever

De werknemer

Bij zowel de werkgever als de werknemer

Bron: ROA/Werkgeverspanel Metalektro 2003

\section{Inzetbaarheid}

Een belangrijk deel van het employability-concept richt zich op de inzetbaarheid van het personeel: De mate waarin het personeel taken kan vervullen die eigenlijk niet tot de eigen functie behoren. In tabel 6.5 wordt een overzicht gegeven van de inzetbaarheid van het technisch personeel naar beroepscategorie.

Bijna de helft van de bedrijven in de Metalektro geeft aan dat hun werknemers goed inzetbaar zijn. Een ongeveer even groot deel van de bedrijven vindt dat hun technisch personeel beperkt inzetbaar is voor taken die niet tot hun functie behoren. Het percentage bedrijven dat aangeeft dat hun technisch personeel niet inzetbaar is voor taken die eigenlijk niet tot hun functie behoren is laag. Alleen voor technici die

15. Zie A. de Grip, J. van Loo en J. Sanders (1999), Employability in bedrijf, Tijdschrift voor Arbeidsvraagstukken, jrg. 15, p. 293-312. 
werkzaam zijn in ontwikkeling en engineering functies is het percentage bedrijven dat vindt dat hun werknemers niet inzetbaar zijn wat hoger, namelijk $9 \%$. Wellicht hangt dit samen met de vaak zeer specifieke inhoud van dergelijke functies.

Tabel 6.5

Inzetbaarheid van het technisch personeel naar beroepscategorie, 2003

Beroepscategorie

Uitvoerende technische functies

Goed inzetbaar

Beperkt inzetbaar

Niet inzetbaar

Leidinggevende technische functies

Goed inzetbaar

Beperkt inzetbaar

Niet inzetbaar

engineering

Goed inzetbaar

Beperkt inzetbaar

Niet inzetbaar

Bron: ROA/Werkgeverspanel Metalektro 2003

De waarde van een goede inzetbaarheid van het personeel komt natuurlijk pas naar voren wanneer er daadwerkelijk gebruik van gemaakt moet worden. Tabel 6.6 geeft een overzicht van de frequentie waarmee bedrijven hun personeel inzetten voor taken die niet tot de eigen functie behoren, uitgesplitst naar beroepscategorie.

Tabel 6.6

Gebruik van inzetbaarheid van het technisch personeel naar beroepscategorie, 2003

Beroepscategorie

Uitvoerende technische functies

Vaak

Af en toe

Zelden

Nooit

Leidinggevende technische functies

Vaak

Af en toe

Zelden

Nooit

Ontwikkeling en engineering

Vaak

Af en toe

Zelden

Nooit

Bron: ROA/Werkgeverspanel Metalektro 2003 
Tweederde van de bedrijven geeft aan dat hun uitvoerend technisch personeel af en toe ingezet wordt voor taken die niet tot hun functie behoren. Bij $10 \%$ van de bedrijven is dat zelfs vaak het geval. Bij ongeveer een kwart van de bedrijven blijkt het uitvoerende technisch personeel daarentegen werkzaam te zijn in functies met strak omschreven taken. Ongeveer zes van de tien bedrijven geeft aan af en toe gebruik te maken van de bredere inzetbaarheid van het leidinggevend technisch personeel. In slechts weinig bedrijven gebeurt dit vaak.

Technici die betrokken zijn bij ontwikkeling en engineering worden slechts af en toe ingezet voor taken buiten de eigen functie. In het grootste deel van de bedrijven (59\%) wordt er echter zelden of nooit gebruik gemaakt van de inzetbaarheid van het personeel dat betrokken is bij ontwikkeling en engineering. Enerzijds kan dit verklaard worden door de specifieke inhoud van de functies. Anderzijds is het zo dat de inzet van het personeel in de ontwikkeling en engineering voor taken die niet tot hun functies behoren vaak te kostbaar is.

Voor de meeste bedrijven is de inzetbaarheid van het technisch personeel van groot belang. Hoewel de cijfers aangaven dat een deel van het technisch personeel niet of slechts beperkt inzetbaar is voor taken die niet tot de eigen functie behoren en er bovendien nog lang niet altijd gebruik wordt gemaakt van deze capaciteiten, is de verdere ontwikkeling van inzetbaarheid voor de meeste bedrijven van groot belang. Maar liefst $93 \%$ van de Metalektrobedrijven geeft namelijk aan dat ze de inzetbaarheid van hun technisch personeel probeert te verhogen. Tabel 6.7 geeft een overzicht van de manieren waarop de bedrijven daaraan invulling geven.

Tabel 6.7

Manieren waarop bedrijf probeert de inzetbaarheid van het technisch personeel te bevorderen c.q. verhogen, $2003^{*}$

Manier

Werknemers om- of bijscholen

Werknemers kennis laten maken met nieuwe taken $\quad 61$

$\begin{array}{ll}\text { Werknemers regelmatig laten wisselen van functie } & 41\end{array}$

Uitwisselingen van werknemers binnen het bedrijf $\quad 29$

$\begin{array}{lr}\text { Uitwisselingen van werknemers buiten het bedrijf } & 7\end{array}$

Anders

* De verschillende percentages staan los van elkaar en hoeven dus niet op te tellen tot $100 \%$. Bron: ROA/Werkgeverspanel Metalektro 2003

Het bij- of omscholen van het personeel is volgens de bedrijven de belangrijkste manier om de inzetbaarheid te bevorderen. Bijna acht van de tien bedrijven geeft aan dat de inzetbaarheid van het technisch personeel wordt gestimuleerd door om- of bijscholing. Naast deze investeringen in formele scholing, vormt ook het op informele wijze bevorderen van de inzetbaarheid, door werknemers in hun werksituatie kennis te laten maken met nieuwe taken, een belangrijk instrument bij de inzetbaarheid van het technisch personeel. Ruim $60 \%$ van de bedrijven geeft aan dat ze op deze wijze de inzetbaarheid probeert te vergroten. 
Functieroulatie wordt door $41 \%$ van de bedrijven gebruikt als instrument om de inzetbaarheid te bevorderen. Daarnaast geeft bijna één op de drie bedrijven aan dat er binnen het bedrijf tussen verschillende productieafdelingen (tijdelijk) werknemers worden uitgewisseld om de inzetbaarheid te stimuleren. Uitwisselingen van werknemers van en naar andere bedrijven komen daarentegen slechts in weinig Metalektrobedrijven voor.

\section{HRM-beleid en inzetbaarheid}

In hoeverre heeft nu het door de bedrijven gevoerde HRM-beleid invloed op de inzetbaarheid van het technisch personeel? Om een antwoord te kunnen geven op deze vraag, is er een analyse uitgevoerd waarin de inzetbaarheid van de drie onderscheiden functiecategorieën is gerelateerd aan de aanwezigheid van de in tabel 6.2 weergegeven HRM-instrumenten. Tabel 6.8 geeft een overzicht van de belangrijkste uitkomsten van deze analyse.

Tabel 6.8

Effect van het gebruik van HRM-instrumenten op de inzetbaarheid van het technisch personeel, naar beroepscategorie, 2003

\begin{tabular}{lccc}
\hline & \multicolumn{3}{c}{ Beroepscategorie } \\
HRM-instrument & $\begin{array}{c}\text { Uitvoerend } \\
\text { technisch }\end{array}$ & $\begin{array}{c}\text { Leidinggevend } \\
\text { technisch }\end{array}$ & $\begin{array}{c}\text { Ontwikkeling en } \\
\text { engineering }\end{array}$ \\
\hline $\begin{array}{l}\text { Opleidingsfaciliteiten } \\
\text { Bedrijfsopleidingenplan (BOP) }\end{array}$ & + & + \\
$\begin{array}{l}\text { Persoonlijk Ontwikkelingsplan (POP) } \\
\text { Competentie- of vaardighedenmatrix }\end{array}$ & & + \\
$\begin{array}{l}\text { Erkenning Verworven Competenties (EVC) } \\
\text { Carrièreplanning }\end{array}$ & & + \\
$\begin{array}{l}\text { Functieroulatie } \\
\text { Functioneringsgesprekken } \\
\text { Beoordelingsgesprekken } \\
\text { Scholingsgesprekken } \\
\text { Geregeld werkoverleg } \\
\text { Loopbaanadvies/mobiliteitscentrum }\end{array}$ & + & + \\
& + & \\
\end{tabular}

Bron: ROA/Werkgeverspanel Metalektro 2003

De inzetbaarheid van het uitvoerend technisch personeel wordt met name door drie HRM-instrumenten positief beïnvloed. Hierbij gaat het om:

- het hebben van een bedrijfsopleidingenplan;

- het houden van beoordelingsgesprekken;

- het voeren van geregeld werkoverleg.

Het is opmerkelijk dat niet het aanbieden van de opleidingsfaciliteiten zelf, maar het hebben van een bedrijfsopleidingenplan de inzetbaarheid van het technisch personeel vergroot. Dit wijst op het belang om op bedrijfsniveau planmatig om te gaan met de gewenste competentie-ontwikkeling van het personeel. Het houden van beoordelingsgesprekken en het geregeld voeren van werkoverleg geven de uitvoerende 
technici kennelijk ook de kans om daadwerkelijk met nieuwe situaties in aanraking te komen, waardoor hun inzetbaarheid vergroot wordt.

Zowel leidinggevend personeel en de werknemers die betrokken zijn bij ontwikkeling en engineering zijn met name beter inzetbaar wanneer er betere opleidingsfaciliteiten in het bedrijf aanwezig zijn. Daarnaast blijkt dat leidinggevende technici beter inzetbaar zijn wanneer er functioneringgesprekken gevoerd worden. Naast andere voordelen van functioneringsgesprekken (carrièreplanning, opleidingsplanning), blijkt het expliciet aan de orde stellen van het functioneren van leidinggevende technici dus ook een positief effect te hebben op hun inzetbaarheid.

Bij het personeel dat betrokken is bij de ontwikkeling en engineering is ook het persoonlijk ontwikkelingsplan (POP) van belang voor de inzetbaarheid. Voor deze groep werknemers blijkt de individuele benadering met betrekking tot de opleidingsbehoefte belangrijk om de inzetbaarheid te vergroten. Ook het toepassen van functieroulatie vergroot voor deze beroepscategorie de inzetbaarheid. Wellicht is het intensiveren van functieroulatie een bruikbaar instrument voor de toch grote groep bedrijven die aangeeft dat de inzetbaarheid van het personeel dat werkzaam is in de ontwikkeling en engineering beperkt is (zie ook tabel 6.5 en 6.6).

\subsection{Een vergelijking met twee andere industriële sectoren}

Het is de vraag hoe het HRM-beleid in de Metalektro zich verhoudt tot de inspanningen die er op dat gebied in andere bedrijfssectoren plaatsvinden. In deze paragraaf vergelijken we het gebruik van HRM-instrumenten in de Metalektro met het gebruik van HRM-instrumenten in twee andere industriële bedrijfssectoren: de voedingssector en de chemie. De gebruikte gegevens zijn afkomstig uit de door de het CBS gehouden Enquête Bedrijfsopleidingen, waarin bedrijven ondervraagd worden over hun opleidingsinspanningen en het gebruik van HRM-instrumenten. Deze informatie is helaas veel minder recent dan de informatie uit de Arbeidsmarktmonitor Metalektro. De Enquête Bedrijfsopleiding is gehouden in 2000 en is voor Nederland één van de weinige bronnen waarmee het HRM-beleid van organisaties tussen bedrijfssectoren vergeleken kan worden.

Tabel 6.9 geeft een overzicht van het gebruik van vijf HRM-instrumenten in de Metalektro, de voedingssector en de chemie. Het gaat daarbij telkens om het percentage bedrijven in de sector dat bepaalde HRM-instrumenten toepast.

Wat betreft het gebruik van HRM-instrumenten blijkt de Metalektro een middenpositie in te nemen in vergelijking met de twee andere grote sectoren in de Nederlandse industrie. Een kwart van de bedrijven in de Metalektro heeft een opleidingsbudget, terwijl in de chemie $40 \%$ van de bedrijven de beschikking heeft over een opleidingsbudget. Daarentegen is dat slechts bij $18 \%$ van de bedrijven in de voedingsindustrie het geval. Drie op de tien Metalektrobedrijven heeft een bedrijfsopleidingenplan, tegenover $40 \%$ van de bedrijven in de chemie. Overigens bleek uit tabel 6.3 dat het percentage Metalektrobedrijven met een bedrijfsopleidingenplan is toegenomen tot $37 \%$. Het aandeel bedrijven dat de beschikking heeft over een intern 
opleidingscentrum is $8 \%$ in de Metalektro en de chemie en $4 \%$ in de voedingssector. Opleidingsfaciliteiten op de werkplek worden door meer dan een kwart van de bedrijven in de Metalektro aangeboden. Functieroulatie, tenslotte, vindt in bijna één op de vijf Metalektrobedrijven plaats. In de voedingssector bedraagt het percentage bedrijven dat functieroulatie inzet $17 \%$, terwijl in de chemie bijna $30 \%$ van de bedrijven gebruik maakt van functieroulatie. Uit tabel 6.3 bleek overigens dat het percentage bedrijven in de Metalektro dat gebruik maakt van functieroulatie de afgelopen jaren min of meer stabiel is gebleven.

Tabel 6.9

Gebruik van HRM-instrumenten in drie bedrijfssectoren

\begin{tabular}{lccc}
\hline & Metalektro & $\begin{array}{c}\text { Bedrijfssector } \\
\text { Voeding } \\
\%\end{array}$ & $\begin{array}{c}\text { Chemie } \\
\%\end{array}$ \\
HRM-instrument & 25 & 18 & 40 \\
Opleidingsbudget & 30 & 22 & 37 \\
Bedrijfsopleidingenplan (BOP) & 8 & 4 & 8 \\
Intern opleidingscentrum & 27 & 21 & 36 \\
Opleidingsfaciliteiten op de werkplek & 19 & 17 & 28 \\
Functieroulatie & & &
\end{tabular}

Bron: ROA/CBS Enquête Bedrijfsopleidingen 2000 



\section{De Metalektro in de toekomst}

Het doen van voorspellingen van hoe de toekomst er uit zal zien is voor een dynamische sector als de Metalektro niet eenvoudig. Toch probeert dit hoofdstuk de belangrijkste toekomstverwachtingen voor de Metalektro in beeld te brengen. Hoe ziet de arbeidsmarkt er in de Metalektro de komende jaren uit? Zijn er nog knelpunten in de personeelsvoorziening te verwachten? In hoeverre vormt het met pensioen gaan van oudere werknemers in de nabije toekomst een probleem? Zullen er bij het werven van bepaalde typen personeel problemen blijven bestaan? Het hoofdstuk sluit af met een bespiegeling van de mogelijke problemen waarmee de Metalektro geconfronteerd zal worden en geeft een overzicht van enkele aandachtspunten die er toe kunnen bijdragen dat de concurrentiekracht van de Metalektro ook in de toekomst op peil blijft.

\subsection{Hoe ziet de arbeidsmarkt in de Metalektro er in de komende jaren uit?}

Naast de schommelingen in de conjunctuur hebben ook structurele veranderingen gevolgen voor de vraag naar arbeid in de Metalektro. Daarbij kan men denken aan de verplaatsing van activiteiten naar andere landen (zie hoofdstuk 1), of de upgrading van de opleidingseisen voor veel functies binnen de Metalektro (zie hoofdstukken 1, 4 en 5).

Daarnaast zijn er ook belangrijke ontwikkelingen in het arbeidsaanbod. Daarbij kan men met name denken aan de toenemende arbeidsuitstroom van ouderen en de geringe instroom van jongeren. In deze paragraaf kijken we naar de verwachte werkgelegenheidsontwikkelingen in de Metalektrosector voor de komende jaren. Daarbij zal ook worden ingegaan op de verwachte arbeidsmarktontwikkelingen voor een aantal specifieke beroepen en opleidingen die voor de Metalektro van belang zijn.

In tabel 7.1 wordt een overzicht gegeven van de verwachte uitbreidingsvraag naar bedrijfssector voor de periode 2003-2008. Het algemene beeld is dat de werkgelegenheid in de meeste sectoren van de industrie de komende jaren zal krimpen. De Metalektrosector is wat dat betreft geen uitzondering. Integendeel, in de Metalektro (inclusief de kleinmetaal) zal de werkgelegenheid sterker afnemen dan in andere industriële sectoren. De verwachting is dat de werkgelegenheid in de Metalektro in vijf jaar tijd met ruim 33.000 werknemers zal krimpen. Dat betekent dat het totale personeelsbestand in de Metalektro de komende jaren met $9 \%$ zal afnemen. $\mathrm{Na}$ de landbouwsector, die traditioneel krimpt, is de Metalektro de bedrijfssector waarvoor de verwachte procentuele krimp van de werkgelegenheid het grootst is.

In de elektrotechniek is de verwachte krimp van de werkgelegenheid met $1,9 \%$ op jaarbasis het grootst. De basismetaal en de transportmiddelenindustrie blijft daar iets bij achter. In aantallen arbeidsplaatsen krimpt de werkgelegenheid naar verwachting 
het sterkst in de electrotechniek en de metaalproduktenindustrie. Voor beide sectoren zal het aantal werkenden de komende jaren met bijna 9.000 afnemen.

Tabel 7.1

Uitbreidingsvraag per bedrijfssector, 2003-2008

\begin{tabular}{|c|c|c|c|}
\hline Bedrijfssector & $\begin{array}{c}\text { Aantal } \\
\text { arbeids- } \\
\text { plaatsen }\end{array}$ & $\begin{array}{c}\text { Totaal } \\
\%\end{array}$ & $\begin{array}{c}\text { Gemiddeld } \\
\text { jaarlijks } \\
\%\end{array}$ \\
\hline Landbouw en visserii & -24.600 & -12 & $-2,6$ \\
\hline Voedingsindustrie & -1.500 & -1 & $-0,2$ \\
\hline Chemie & -7.200 & -6 & $-1,3$ \\
\hline Metalektro & -33.300 & -9 & $-1,9$ \\
\hline - Basismetaal & -2.200 & -8 & $-1,7$ \\
\hline - Metaalprodukten & -8.900 & -9 & $-1,8$ \\
\hline - Machine-industrie & -8.300 & -9 & $-1,8$ \\
\hline - Elektrotechniek & -8.900 & -9 & -1.9 \\
\hline - Transportmiddelen & -5.000 & -8 & $-1,7$ \\
\hline Overige industrie & -23.200 & -6 & $-1,2$ \\
\hline Energie & 1.100 & 2 & 0,4 \\
\hline Bouw en onroerend goed & -15.400 & -3 & $-0,6$ \\
\hline Handel en reparatie & 22.000 & 2 & 0,4 \\
\hline Transport en communicatie & -20.300 & -5 & $-1,0$ \\
\hline Bank- en verzekeringswezen & 17.300 & 6 & 1,3 \\
\hline Horeca en zakelijke dienstverlening & 37.100 & 3 & 0,6 \\
\hline Kwartaire diensten & 67.800 & 6 & 1,1 \\
\hline Overheid en onderwijs & 53.300 & 5 & 1,0 \\
\hline Totaal & 83.100 & 6 & 0,2 \\
\hline
\end{tabular}

Bron: ROA/CPB/CBS en FME-CWM Conjunctuurmonitor 2003

\section{Arbeidsmarktprognoses voor specifieke functies}

Tabel 7.2 laat zien dat de uitbreidingsvraag voor bijna alle voor de Metalektro relevante beroepen negatief is. Alleen voor magazijnpersoneel, medisch instrumentenmakers en installateurs is er de komende jaren naar verwachting nog sprake van een bescheiden groei van de werkgelegenheid. Ondanks de dalende werkgelegenheid in de meeste beroepen zijn er toch ook de komende jaren behoorlijk wat 'baanopeningen'16 te verwachten. Deze baanopeningen zijn grotendeels het gevolg van de vervangingsvraag: de vraag naar nieuwe werknemers die voor het grootste gedeelte het gevolg is van het vertrek van oudere werknemers die de arbeidsmarkt verlaten vanwege pensioen of pré-pensionering.

16. Onder baanopeningen verstaat men het (netto) aantal banen dat er vrij komt voor mensen die nog niet in de sector werkzaam zijn. Het aantal baanopeningen is veel lager dan het aantal vacatures, omdat er in de praktijk sprake is van zogenaamde 'vacatureketens'. Deze ontstaan als een vacature wordt ingevuld door iemand die bij een ander bedrijf in een soortgelijke functie werkzaam was en na vertrek ook weer een vacature achterlaat. 
Het percentage baanopeningen van nieuwkomers op de arbeidsmarkt is het hoogst voor receptionisten en administratieve employés $(4,4 \%)$. Bij de technische functies is de vervangingsvraag het grootst voor de werktuigbouwkundig ontwerpers en hoofden technische dienst $(4,1 \%)$, medisch instrumentenmakers en installateurs (beide $3,6 \%$ ). Voor commercieel medewerkers op universitair niveau, assembleurs en elektromonteurs is het percentage baanopeningen naar verwachting de komende jaren het kleinst.

Tabel 7.2

Uitbreidingsvraag, vervangingsvraag en baanopeningen per beroepsgroep (als gemiddeld jaarlijks percentage van de werkgelegenheid), 2003-2008

\begin{tabular}{|c|c|c|c|}
\hline Beroepsgroep & $\begin{array}{c}\text { Uitbreidings- } \\
\text { vraag } \\
\%\end{array}$ & $\begin{array}{c}\text { Vervangings- } \\
\text { vraag } \\
\%\end{array}$ & $\begin{array}{c}\text { Baan- } \\
\text { openingen } \\
\%\end{array}$ \\
\hline \multicolumn{4}{|l|}{ Technische functies } \\
\hline Monteurs & $-1,3$ & 3,1 & 3,1 \\
\hline Metaalbewerkers & $-1,1$ & 3,1 & 3,2 \\
\hline Bankwerkers en lassers & $-0,7$ & 3,0 & 2,9 \\
\hline Elektromonteurs & $-1,0$ & 2,8 & 2,8 \\
\hline Productiemedewerkers & $-2,1$ & 3,1 & 3,0 \\
\hline $\begin{array}{l}\text { Werktuigbouwkundig ontwerpers en hoofden } \\
\text { technische dienst }\end{array}$ & $-2,4$ & 4,1 & 4,1 \\
\hline Assembleurs & $-0,9$ & 2,7 & 2,6 \\
\hline Magazijnpersoneel & 1,3 & 2,1 & 3,2 \\
\hline Medisch instrumentenmakers & 1,3 & 2,3 & 3,6 \\
\hline Installateurs & 0,8 & 2,9 & 3,6 \\
\hline \multicolumn{4}{|l|}{ Administratieve en commerciële functies } \\
\hline Administratief personeel & 1,2 & 2,4 & 3,5 \\
\hline Commercieel medewerkers (HBO niveau) & $-1,3$ & 2,9 & 2,9 \\
\hline Receptionisten en administratieve employés & $-0,5$ & 4,4 & 4,4 \\
\hline Commercieel medewerkers (WO niveau) & $-0,5$ & 2,5 & 2,4 \\
\hline
\end{tabular}

\section{Bron: $\mathrm{CBS} / \mathrm{CPB} / \mathrm{ROA}$}

In tabel 7.3 wordt de verwachte vraag naar personeel afgezet tegen het verwachte aanbod. Op deze wijze ontstaat de Indicator Verwachte Knelpunten in de personeelsvoorziening naar Beroep (ITKB). ${ }^{17}$ Vanwege de negatieve werkgelegenheidsontwikkeling zullen de knelpunten in de personeelsvoorziening de komende jaren naar verwachting zeer beperkt blijven. Alleen voor elektromonteurs en medisch instrumentenmakers worden nog grote knelpunten verwacht. Daarnaast zal er voor met name werktuigbouwkundig ontwerpers en hoofden technische dienst en voor installateurs soms nog sprake zijn van enige knelpunten in de personeelsvoorziening.

17. Een nadere uitleg van deze indicator is te vinden in ROA (2003), De arbeidsmarkt naar opleiding en beroep tot 2008, ROA-R-2003/11, Maastricht. 
Tabel 7.3

Indicator Toekomstige Knelpunten in de personeelsvoorziening naar Beroep (ITKB) voor de belangrijkste beroepen binnen de Metalektro, 2003-2008

\begin{tabular}{lll}
\hline Beroepsgroep & ITKB & Typering \\
\hline & & \\
\hline Technische functies & & \\
Monteurs & 0,92 & vrijwel geen \\
Metaalbewerkers & 0,95 & geen \\
Bankwerkers en lassers & 0,89 & enige \\
Elektromonteurs & 0,88 & groot \\
Productiemedewerkers & 0,96 & geen \\
Werktuigbouwkundig ontwerpers en hoofden technische dienst & 0,89 & enige \\
Assembleurs & 0,97 & geen \\
Magazijnpersoneel & 0,97 & geen \\
Medisch instrumentenmakers & 0,80 & groot \\
Installateurs & 0,89 & enige \\
& & \\
Administratieve en commerciële functies & & \\
Administratief personeel & 0,92 & vrijwel geen \\
Commercieel medewerkers (HBO niveau) & 0,93 & vrijwel geen \\
Receptionisten en administratieve employés & 0,96 & geen \\
Commercieel medewerkers (WO niveau) & 0,92 & vrijwel geen \\
& &
\end{tabular}

Bron: ROA

\section{Arbeidsmarktprognoses voor specifieke opleidingen}

In tabel 7.4 wordt de verwachte arbeidsmarktsituatie vanuit het perspectief van de vraag naar en het aanbod van bepaalde opleidingstypen nader belicht. Voor de meeste van de voor de Metalektro relevante opleidingsrichtingen is de verwachte uitbreidingsvraag de komende jaren negatief. Voor enkele opleidingen op de lagere niveaus (bijvoorbeeld voor mensen met alleen basisonderwijs of mensen met een opleiding VMBO mechanische techniek) wordt er een forse krimp verwacht. De opleidingen waarvoor de verwachte uitbreidingsvraag positief is, zijn zonder uitzondering opleidingen op middelbaar en hoger niveau, zoals bijvoorbeeld HAVO/VWO en HBO bedrijfskunde.

De verwachte vervangingsvraag is het grootst voor werknemers met een opleiding MBO werktuigbouw en mechanische techniek en voor mensen die alleen basisonderwijs gevolgd hebben. Dat valt waarschijnlijk te verklaren door het hoge aandeel van oudere werknemers met deze opleidingen, die door het verlaten van de arbeidsmarkt als gevolg van pensioen of pré-pensionering, ruimte zullen maken voor nieuwkomers. In de derde kolom van tabel 7.4 wordt een overzicht gegeven van het verwachte aantal baanopeningen. Voor de meeste opleidingstypen ligt het aantal baanopeningen rond de vier procent op jaarbasis. Door de verwachte vervangingsvraag zal het aantal baanopeningen naar verwachting het grootst zijn voor werknemers met alleen basisonderwijs, HAVO/VWO of een opleiding elektrotechniek op MBO niveau. 
Tabel 7.4

Uitbreidingsvraag, vervangingsvraag, baanopeningen en instroom van schoolverlaters per opleidingstype (als gemiddeld jaarlijks percentage van de werkgelegenheid), 2003-2008

\begin{tabular}{lcccc}
\hline Opleidingstype & $\begin{array}{c}\text { Uitbreidings- } \\
\text { vraag } \\
\%\end{array}$ & $\begin{array}{c}\text { Vervangings- } \\
\text { vraag } \\
\%\end{array}$ & $\begin{array}{c}\text { Baan- } \\
\text { openingen } \\
\%\end{array}$ & $\begin{array}{c}\text { In- } \\
\text { stroom } \\
\%\end{array}$ \\
\hline Technische opleidingen & & & & \\
MBO werktuigbouw en mechanische techniek & $-0,5$ & 4,0 & 3,9 & 2,0 \\
VMBO mechanische techniek & $-4,5$ & 3,9 & 4,0 & 3,6 \\
MBO elektrotechniek & 1,1 & 3,5 & 4,5 & 2,8 \\
HBO werktuigbouwkunde & $-0,2$ & 3,4 & 3,4 & 3,6 \\
HBO elektrotechniek & 1,2 & 3,7 & 4,7 & 2,9 \\
VMBO bouwtechniek & $-1,0$ & 3,6 & 3,7 & 4,9 \\
& & & & \\
Overige opleidingen & $-5,2$ & 4,4 & 4,7 & 5,1 \\
Basisonderwijs & $-0,3$ & 3,9 & 3,9 & 4,2 \\
VMBO theorie & 1,8 & 2,8 & 4,5 & 5,3 \\
HAVO/VWO & 0,6 & 3,9 & 4,4 & 2,9 \\
MBO administratie en logistiek & $-1,1$ & 3,9 & 3,9 & 4,5 \\
MBO handel & 1,3 & 1,9 & 3,0 & 5,4 \\
HBO bedrijfskunde & & & & \\
\hline Bron: CBS/CPB/ROA & & & &
\end{tabular}

Bron: $\mathrm{CBS} / \mathrm{CPB} / \mathrm{ROA}$

In tabel 7.5 wordt voor de belangrijkste opleidingstypen in de Metalektro de verwachte vraag naar personeel gerelateerd aan de verwachte arbeidsmarktinstroom. We noemen dit de Indicator Toekomstige Knelpunten in de Personeelsvoorziening (ITKP). ${ }^{18}$

Tabel 7.5

Indicator Toekomstige Knelpunten in de Personeelsvoorziening (ITKP) voor de belangrijkste opleidingstypen binnen de Metalektro, 2003-2008

\begin{tabular}{lll}
\hline Opleidingstype & ITKP & Typering \\
\hline & & \\
MBO werktuigbouw en mechanische techniek & 1,01 enige \\
Basisonderwijs & 1,39 geen \\
VMBO mechanische techniek & 1,33 geen \\
MBO elektrotechniek & 0,97 groot \\
VMBO theorie & 1,15 vrijwel geen \\
HAVO/VWO & 1,15 vrijwel geen \\
HBO werktuigbouwkunde & 1,04 enige \\
MBO administratie en logistiek & 0,99 groot \\
HBO elektrotechniek & 0,94 groot \\
VMBO bouwtechniek & 1,28 geen \\
MBO handel & 1,18 geen \\
HBO bedrijfskunde & 1,13 vrijwel geen \\
\end{tabular}

Bron: ROA

18. Een nadere uitleg van deze indicator is te vinden in ROA (2003), De arbeidsmarkt naar opleiding en beroep tot 2008, ROA-R-2003/11, Maastricht. 
Voor drie van de genoemde opleidingstypen zal er naar verwachting sprake zijn van grote knelpunten in de personeelsvoorziening: MBO elektrotechniek, MBO administratie en logistiek en HBO elektrotechniek. Voor deze opleidingscategorieën zal de werkgelegenheid de komende jaren groeien, terwijl de arbeidsmarktinstroom van nieuw personeel zelfs achterblijft bij de vervangingsbehoefte. Overigens worden er over de hele linie van technisch opgeleiden op HBO en Universitair niveau knelpunten in de personeelsvoorziening verwacht. ${ }^{19}$

Voor de opleidingen MBO werktuigbouw en mechanische techniek zal er slechts in beperkte mate sprake zijn van knelpunten in de personeelsvoorziening. Uit de tabel blijkt duidelijk dat in vergelijking met vorige jaren het aantal verwachte knelpunten in de personeelsvoorziening sterk is gedaald. In 2002 werden er nog voor vrijwel alle voor de Metalektro relevante opleidingen op MBO of HBO niveau grote knelpunten verwacht.

\section{Verwachte problemen op de korte termijn}

Ook op de korte termijn verwachten weinig bedrijven problemen bij het vinden van technisch personeel. Tabel 7.9 laat zien dat bijna $40 \%$ van de bedrijven het komend jaar geen problemen verwacht bij het vinden van technisch personeel. Slechts een kleine minderheid van de bedrijven $(4 \%)$ verwacht dat de problemen zullen toenemen.

Tabel 7.9

Verwachte problemen bij het vinden van technisch personeel over een jaar, 2003

\section{Problemen}

Problemen nemen toe

Problemen blijven gelijk

Problemen nemen af

Geen idee/geen mening

Bron: ROA/Werkgeverspanel Metalektro 2003

De kleine groep bedrijven die aangeeft dat de problemen zullen toenemen verwacht overigens relatief vaak dat dit het gevolg is van de afname van het beschikbare aantal schoolverlaters. De helft van de bedrijven geeft daarnaast aan dat ook de vergrijzing van het personeelsbestand hierbij een belangrijke rol speelt. Bij die bedrijven die verwachten dat de problemen zullen afnemen geldt het tegenovergesteld argument. Deze bedrijven verwachten juist een verruimd aanbod van potentiële werknemers.

19. ROA (2003), De arbeidsmarkt naar opleiding en beroep tot 2008, ROA-R-2003/11, Maastricht, 2003. 


\subsection{Technische werknemers met pensioen: en dan?}

De toekomstige uitstroom van technisch personeel door pensioen of prépensionering is een belangrijk aandachtspunt voor veel Metalektrobedrijven. Tabel 7.6 geeft een overzicht van de verwachte uitstroom door pensioen of prépensionering in de komende vijf jaar. Uit de tabel blijkt dat er tussen bedrijven grote verschillen bestaan in het voor de komende jaren te verwachten personeelsverloop vanwege (pré)-pensionering. In iets meer dan de helft van de Metalektrobedrijven blijft de pensioenuitstroom beperkt tot maximaal $5 \%$ van het personeelsbestand. In deze bedrijven gaat naar verwachting in de komende vijf jaar slechts één op de 20 werknemers met pensioen. Bijna drie op de tien bedrijven geeft aan dat de pensioenuitstroom naar verwachting 6 tot $10 \%$ van het personeelsbestand zal bedragen. Daarentegen heeft $20 \%$ van de Metalektro bedrijven te maken met een pensioenuitstroom van $11 \%$ of meer. Met name deze bedrijven zullen de komende jaren veel nieuw personeel moeten aantrekken, vanwege de hoge arbeidsmarktuitstroom van hun vergrijsde personeelsbestand.

Tabel 7.6

Gemiddeld percentage verwachte pensioenuitstroom van bedrijven in de komende vijf jaar, 2003

Gemiddeld percentage

0 tot en met $5 \%$

11 tot en met $15 \%$

16 tot en met $20 \%$

21 tot en met $25 \%$

26 tot en met $30 \%$

Meer dan $30 \%$

Bron: ROA/Werkgeverspanel Metalektro 2003

Zes procent van de bedrijven voorziet ook grote problemen bij de vervanging van het technisch personeel dat de komende jaren met pensioen zal gaan (zie figuur 7.1). Ongeveer één op de vijf bedrijven geeft aan problemen te verwachten, maar vindt dat die wel oplosbaar zijn.

Tabel 7.7

Redenen waarom vergrijzing geen probleem vormt, 2003*

Reden

Weinig werknemers met pensioen

${ }^{*}$ De verschillende percentages staan los van elkaar en hoeven dus niet op te tellen tot $100 \%$. Bron: ROA/Werkgeverspanel Metalektro 2003 
Aan de bedrijven die geen problemen verwachten is gevraagd waarom dat in hun bedrijf het geval is. Tabel 7.7 geeft aan dat de meeste bedrijven aangeven dat de ontstane vacatures eenvoudig opvulbaar zullen zijn (58\%). Daarnaast vindt vier op tien bedrijven dat er geen problemen zullen zijn doordat er eenvoudigweg weinig werknemers met pensioen zullen gaan. Ongeveer eenzelfde deel geeft aan dat er geen problemen zullen ontstaan doordat de ontstane vacatures niet zullen worden opgevuld.

Figuur 7.1

Verwachte problemen met de vervanging van technische werknemers die binnen vijf jaar met (vervroegd) pensioen zullen gaan

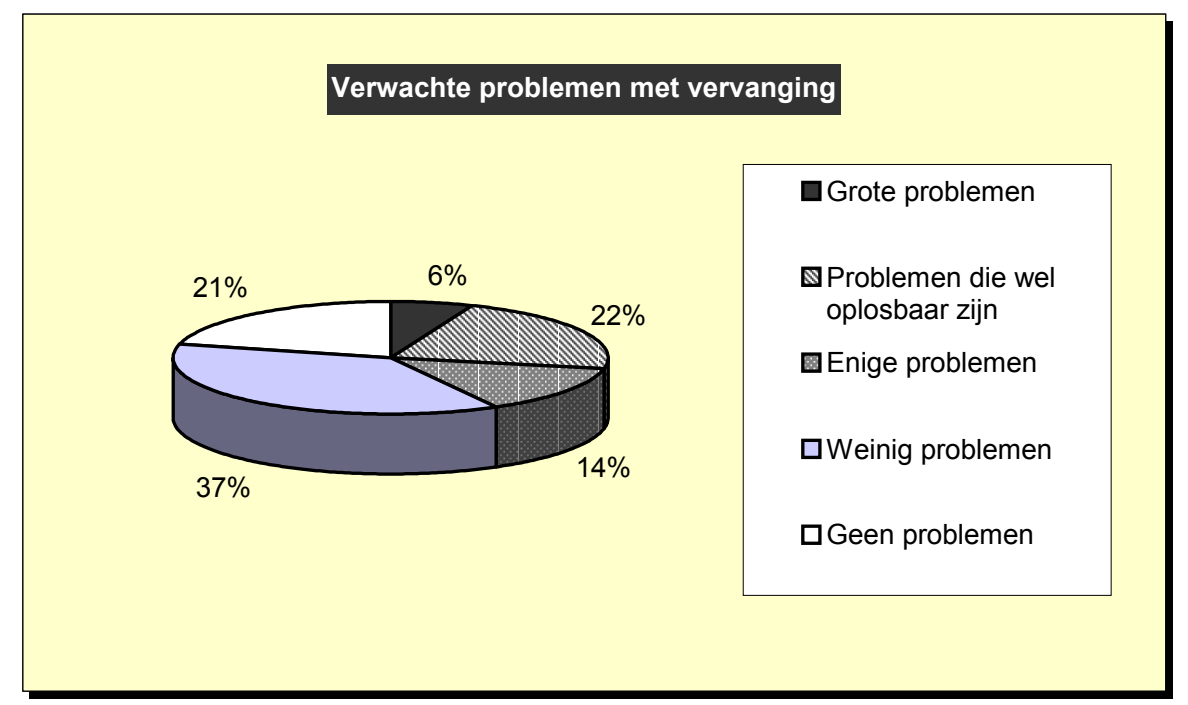

Bron: ROA/Werkgeverspanel Metalektro 2003

In vergelijking met 2002 is het percentage bedrijven dat verwacht problemen te hebben met de vervanging van gepensioneerd personeel flink gedaald. Blijkbaar vermindert de minder goede economische situatie en de daaruit voortvloeiende verwachte werkgelegenheidskrimp de problemen die er als gevolg van de pensionering van oudere werknemers ontstaan. Een deel van deze uitstromende werknemers zal immers de komende jaren niet vervangen worden. Daarnaast zullen er ook meer geschikte instromers beschikbaar zijn vanwege de in zijn totaliteit geringere behoefte aan nieuwe werknemers in de Metalektro.

\section{Problemen per functie}

Als een bedrijf problemen verwacht bij de vervanging van gepensioneerd personeel, dan is het de vraag voor welke functies dat vooral het geval is. In figuur 7.2 wordt er per beroep gekeken in hoeverre bedrijven veel of weinig problemen verwachten. Uit de figuur blijkt dat alleen voor machinaal verspaners en in iets mindere mate voor lassers, een aanzienlijk deel van de bedrijven aangeeft dat ze veel problemen verwacht bij de vervanging van personeel dat de komende jaren met pensioen gaat. 
Voor pijpverwerkers en overige geschoolde vaklieden verwacht de meerderheid van de bedrijven helemaal geen vervangingsproblemen.

Figuur 7.2

Verwachte problemen met de vervanging van technische werknemers die binnen vijf jaar met (vervroegd) pensioen zullen gaan, naar functiegroep

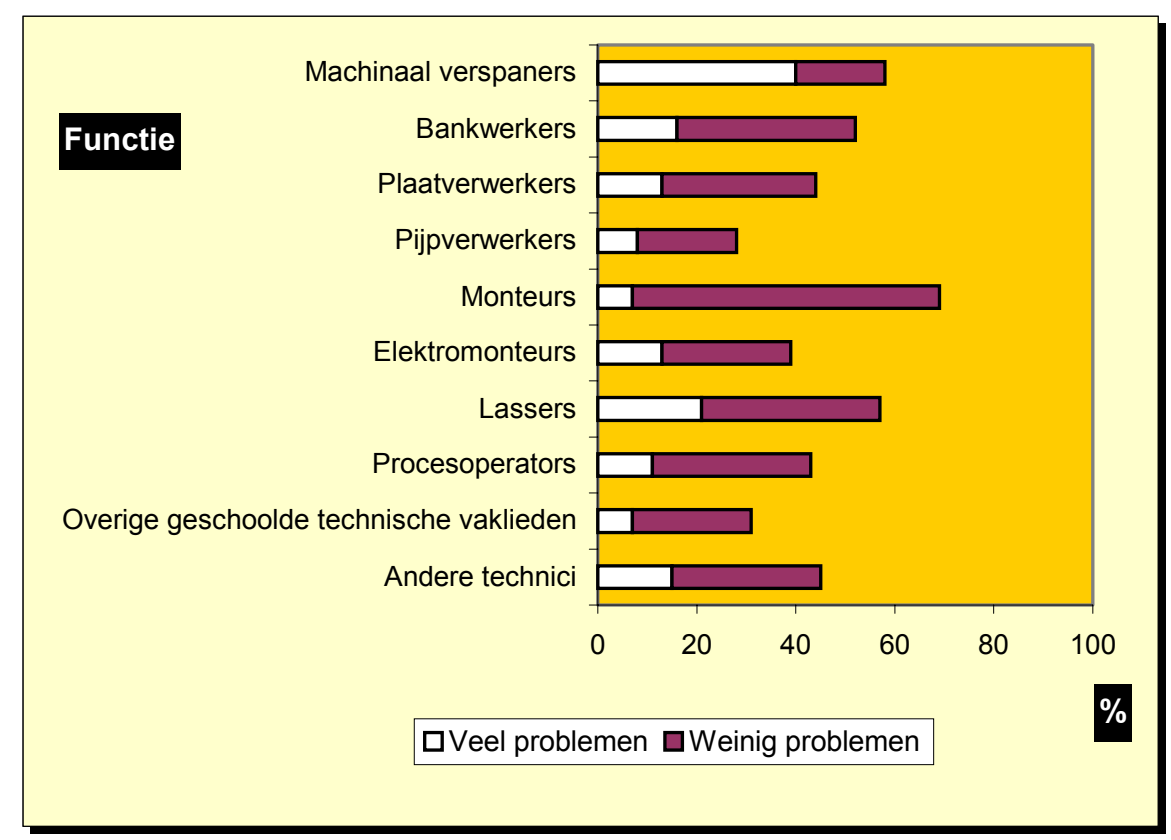

Bron: ROA/Werkgeverspanel Metalektro 2003

Voor bedrijven die in de toekomst wel problemen bij de vervanging van gepensioneerd technisch personeel verwachten is het van groot belang daar nu al op in te spelen. Tabel 7.8 geeft een overzicht van de maatregelen die bedrijven momenteel reeds treffen om de toekomstige problemen te beperken.

De meeste bedrijven proberen de toekomstige problemen een halt toe te roepen door het opleiden van het personeel. Daarbij is het aannemen van werknemers en deze vervolgens opleiden de meest gevolgde aanpak: In meer dan acht van de tien bedrijven wordt er personeel aangenomen dat vervolgens door scholing op het gewenste niveau wordt gebracht. Ruim de helft van de bedrijven dat toekomstige problemen verwacht met de vervanging van pensioengangers geeft bovendien aan dat ze toekomstige wervingsproblemen proberen op te vangen door te investeren in de om- en bijscholing van het zittende personeel.

Ook taakroulatie met als doel het personeel breder inzetbaar te maken is een veel toegepaste maatregel om problemen met de vervanging van gepensioneerd personeel in de toekomst te beperken. Circa vier van de tien bedrijven in de Metalektro laat het personeel regelmatig wisselen van taken. Daarnaast wordt de werving van nieuw gekwalificeerd vaak genoemd als maatregel die bedrijven nu reeds nemen. Maatregelen zoals het stimuleren van de loopbaanontwikkeling, het 
introduceren van arbeidsbesparende technologie, een grotere aandacht voor het wervingsbeleid, en het tijdelijk aannemen van extra personeel komen bij een minderheid van de bedrijven voor. Er zijn slechts weinig bedrijven die vanwege de verwachte toekomstige vervangingsproblemen ertoe overgaan de leeftijd waarop mensen met pensioen gaan uit te stellen, of overwegen hun productie naar het buitenland te verplaatsen.

Tabel 7.8

Maatregelen om de problemen met de vervanging van gepensioneerd van technisch personeel te beperken, 2003*

Maatregelen

Aannemen werknemers en opleiden

Om- en bijscholing van het personeel

Door taakroulatie werknemers breder inzetbaar maken $\quad 42$

Aannemen goede werknemers $\quad 36$

$\begin{array}{lr}\text { Stimulering loopbaanontwikkeling } & 28\end{array}$

Arbeidsbesparende technologie $\quad 25$

$\begin{array}{ll}\text { Meer aandacht voor wervingsbeleid } & 24\end{array}$

$\begin{array}{lr}\text { Tijdelijke werving extra personeel } & 16\end{array}$

$\begin{array}{lr}\text { Productie verplaatsen } & 4\end{array}$

$\begin{array}{ll}\text { Uitstel pensioen- of VUTleeftijd } & 4\end{array}$

* De verschillende percentages staan los van elkaar en hoeven dus niet op te tellen tot $100 \%$. Bron: ROA/Werkgeverspanel Metalektro 2003

\subsection{Agenda voor de toekomst}

Zoals in paragraaf 7.1 werd uiteengezet, zal de Metalektro naar verwachting de komende jaren als gevolg van de voorspelde werkgelegenheidskrimp, slechts in beperkte mate geconfronteerd worden met grote knelpunten in hun personeelsvoorziening. De belangrijkste uitdaging voor het arbeidsmarkt- en personeelsbeleid in de Metalektro zal de komende jaren dan ook niet betrekking hebben op de kwantitatieve arbeidsmarktproblematiek. In tegendeel, alle signalen wijzen in de richting van een kwalitatieve personeelsproblematiek.

Deze kwalitatieve personeelsproblematiek is het gevolg van de samenloop van twee cruciale ontwikkelingen:

- de voortschrijdende upgrading van het niveau van het werk;

- de voortschrijdende vergrijzing van het personeel.

\section{Upgrading}

In verschillende hoofdstukken van dit rapport is reeds uitgebreid ingegaan op de upgrading van de competentie-eisen die aan het personeel in de Metalektro moeten worden gesteld. Zowel de introductie van nieuwe producten, als de innovatie van productieprocessen stelt steeds hogere eisen aan het personeel. Voor de concurrentiepositie van de Nederlandse Metalektro-industrie is het dan ook van groot belang dat bedrijven zich richten op het produceren en vermarkten van hoogwaardige producten en diensten. Bedrijven die zich hierop toeleggen concurreren 
primair op basis van de kwaliteit van hun producten en dienstverlening. Ze moeten beschikken over goed opgeleid personeel dat weet om te gaan met de meest moderne technologie. Hun personeel moet naast vaktechnische kennis en vaardigheden ook beschikken over voldoende communicatieve vaardigheden en oog hebben voor de wensen van de klanten.

Wat dit betreft is het zorgwekkend dat één op de tien bedrijven aangeeft dat hun technisch personeel met een groot tekort aan vaktechnische vaardigheden kampt. In nog meer bedrijven hebben technici onvoldoende communicatieve competenties en een tekortschietend probleemoplossend vermogen. In dit kader moet er ook meer aandacht komen voor het feit dat ruim eenderde van het personeel in de Metalektro alleen basisonderwijs of een VMBO opleiding heeft gevolgd. De upgrading van de voor het werk in de Metalektro vereiste competenties maakt het van groot belang dat via EVC projecten de competenties van het personeel meer transparant gemaakt worden. Bovendien kan op deze manier worden gestimuleerd dat lager opgeleiden aanvullende scholing gaan volgen die hun inzetbaarheid in de toekomst zal vergroten.

De verwachte personeelstekorten zullen de komende jaren vooral betrekking hebben op mensen met een MBO opleiding elektrotechniek en op technici met een HBO of universitaire opleiding. Voor de Nederlandse Metalektro-industrie is het daarom van groot belang dat het Deltaplan Bèta-techniek een impuls zal weten te geven aan de belangstelling voor de bèta-techniek opleidingen.

Voor de meeste Metalektrobedrijven is de inzetbaarheid van het technisch personeel ook van groot belang. Vrijwel alle Metalektrobedrijven geven dan ook aan dat ze de inzetbaarheid van hun personeel proberen te verhogen. Dit maakt het van groot belang om voldoende te blijven investeren in de bij- of omscholing van het personeel en het vergroten van de employability van het personeel. Het is dan ook terecht dat het Human Resource Management (HRM) tegenwoordig in veel Metalektrobedrijven een centrale plaats inneemt in het strategisch beleid.

Een goede ontwikkeling is ook dat de evaluatie en planning van scholingsactiviteiten door middel van scholingsgesprekken sterk is toegenomen. Hierdoor kan er meer aandacht worden besteed aan het vinden van passende scholing en worden de investeringen in opleidingen ook beter geëvalueerd. Deze professionalisering van het HRM beleid zal het rendement van het opleidingsbeleid kunnen vergroten.

Het verhogen en up-to-date houden van het competentieniveau van het personeel in de Metalektro en het vergroten van hun inzetbaarheid zal ook in belangrijke bepalend zijn voor de mate waarin Metalektrobedrijven zich in Nederland zullen (blijven) vestigen. Het goede niveau van het technisch personeel in Nederland en de nabijheid van R\&D activiteiten maken het immers voor veel bedrijven aantrekkelijk om in Nederland gevestigd te zijn. 
De voortschrijdende vergrijzing van het technisch personeel in de Metalektro heeft twee belangrijke gevolgen. In de eerste plaats betekent het dat de komende jaren het personeelsverloop vanwege pensionering sterk zal toenemen. In de tweede plaats kan het betekenen dat de komende jaren belangrijke ervaringskennis verloren gaat. Slechts een kwart van de bedrijven verwacht dat de hogere uitstroom vanwege pensionering tot problemen zal leiden. Met kan zich afvragen of de andere bedrijven wel voldoende beseffen welke gevolgen deze personeelsuitstroom kan hebben voor het verloren gaan van belangrijke ervaringskennis en vakmanschap. Wat dit betreft is het van groot belang dat hierop wordt geanticipeerd door kennisoverdracht van het oudere naar het jongere personeel, e.d. 